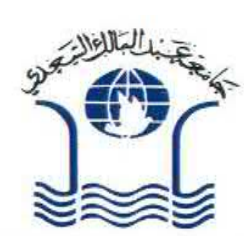

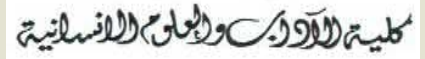

مشتوات: جامتة عبد المالك السعديى

كليت الأذاب والعلع الإنسانية - نطوان

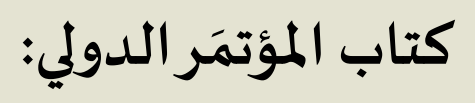

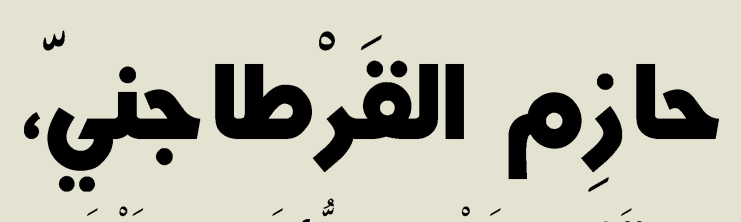

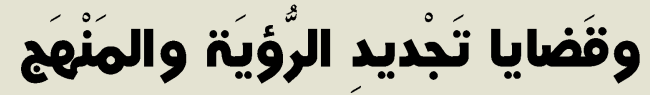

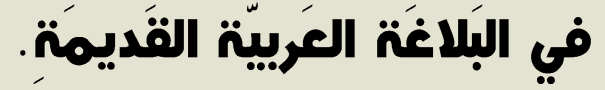

\author{
من تنظيم شعبة اللغة العربية وآدابها، بكلية الآداب بتطوان

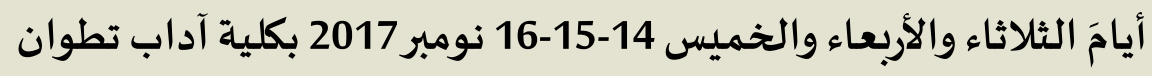

:تجع وإعداد نُشئيب :

د. عبد الرمن بوديك 


\section{تداولية المعنى عند حازم القرطاجني: الأسس المنطقية والتناول اللساني}

د.عبد الرحمن محمد طعمة

قسم اللغة العربية، كلية الآداب، جامعة القاهرة، مصر

المدخل:

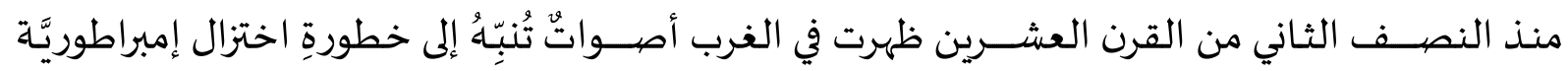

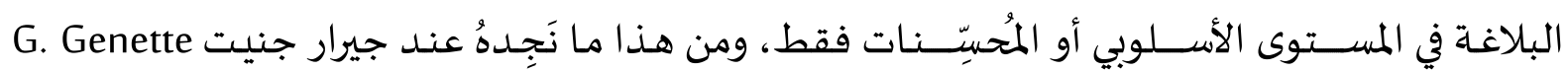

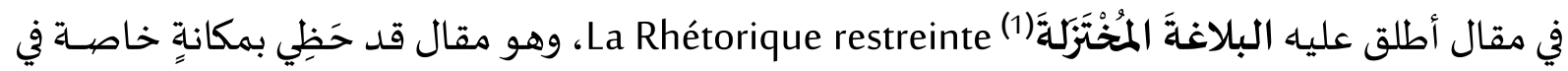

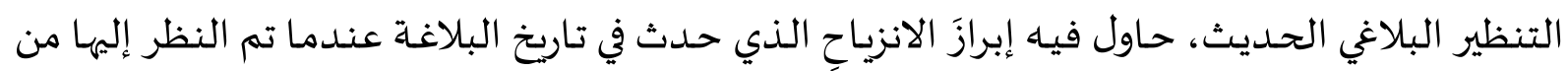

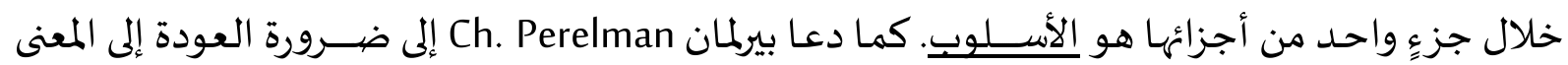

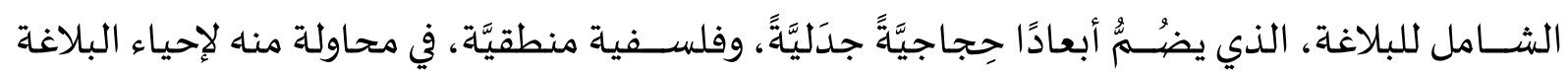

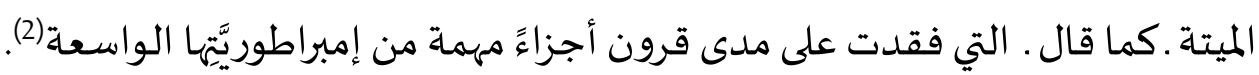

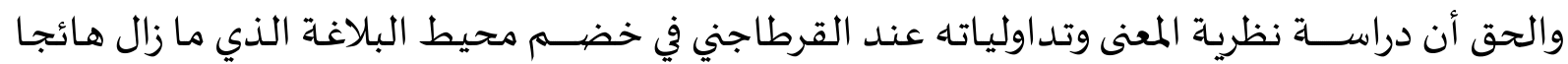

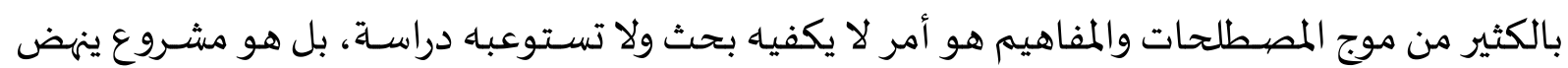

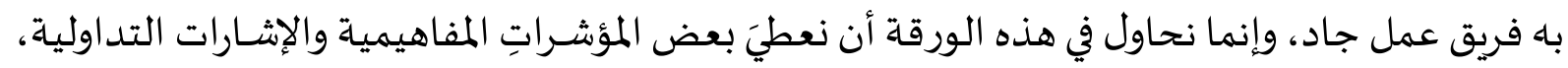

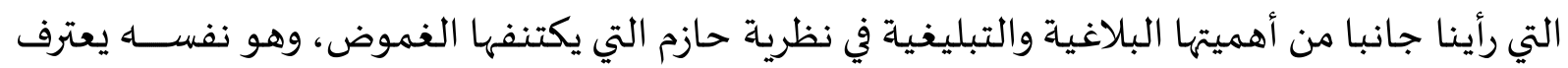
بمثل ما نذهب إليه من وعورة هذا السـبيل؛ فيقول في تبيان مدى اتســاع مجال البلاغة في عموماه ورحابة

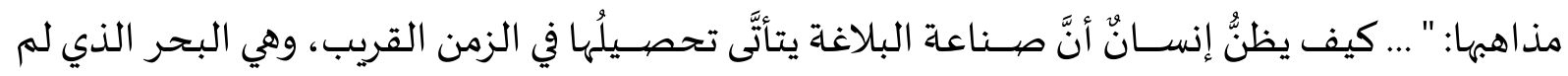

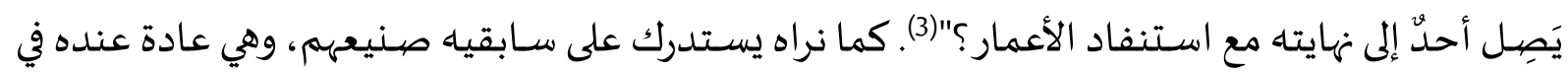
صـوغ قوانين الاستنباط المنطقية عموما، فنراه يقف على الجهد الفلسـفي لأرسـطو، صهاحب التأثير الكبير عليه - بالإضـافة لابن سينا بالطبع - في فن الشعر خصوصيا المسيطر على جُل المنهاج، فيقول: "ولو وجـَ

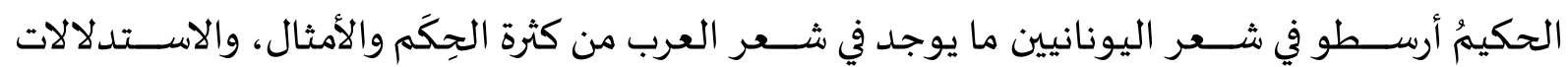

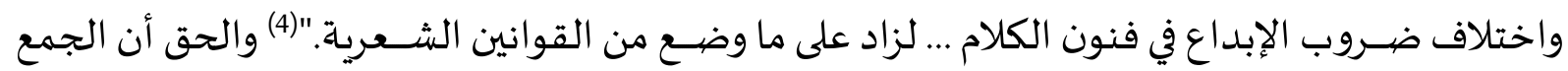

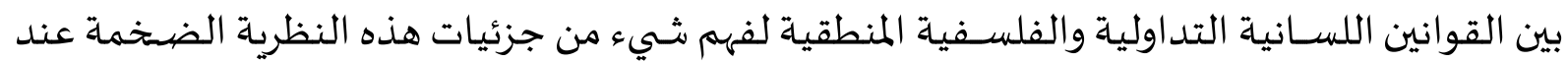
القرطاجني هو أحسد ســبل الفهم العام، التي نحاول من خلالها اســـعراض مختارات من جوانهها المتداخلة

لفك ما قد يبدو من اشتباك ظاهري بينها.

G. Genette: Rhétorique restreinte, Edition du seuil, Paris, 1972, Pp 21 - 40. (1)

Ch. Perelman: L'empire Rhétorique, Librairie Philosophique, 1977, P 13. (2)

(3) القرطاجني (أبو الحسن، حازم) (1211 - 1386 م): منهاج البلغاء وسراج الأدباء، تقديم وتحقيق محمد الحبيب

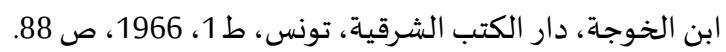

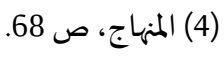


وســنقسـم الدراســة عموما إلى أقســام ثلاثة: الأول منها يعالج قضـية المعنى في عموماه وكلياته المعرفياة.

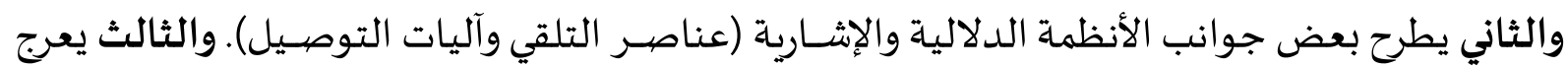

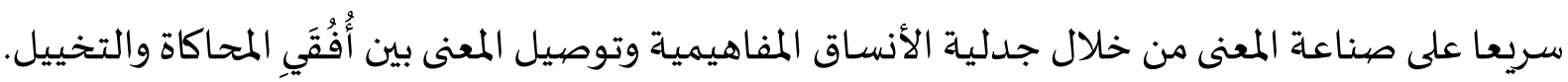

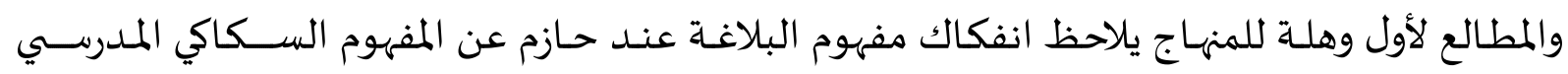

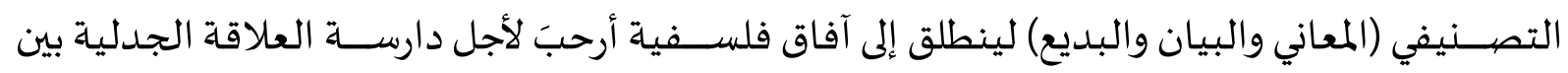
اللفظ والمعنى، وهو ما سنشير إليه في القسم الأول من هذه الدراسة، مقارنة بأحد أعلام المام البلاغيين الكبار،

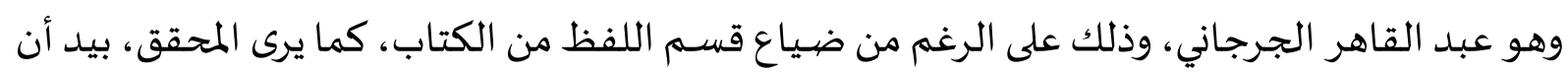

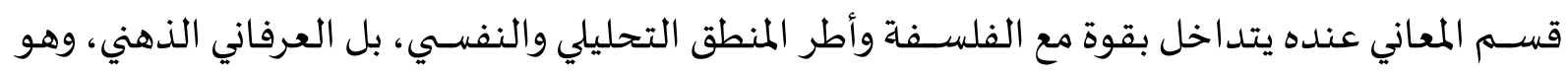
أمر أوسع من البحث البلاغي التقليدي.

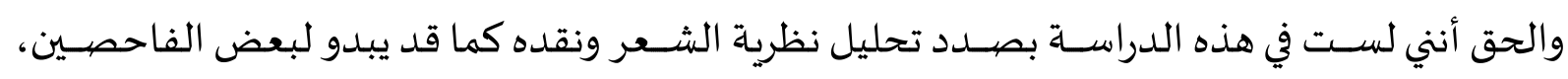

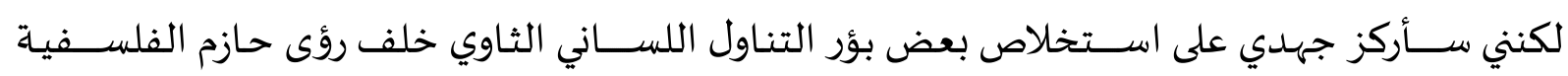

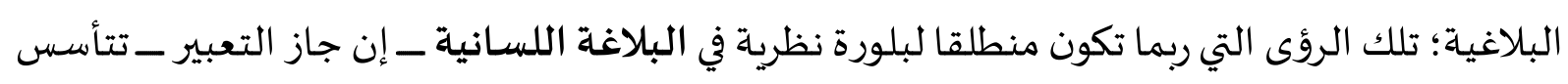

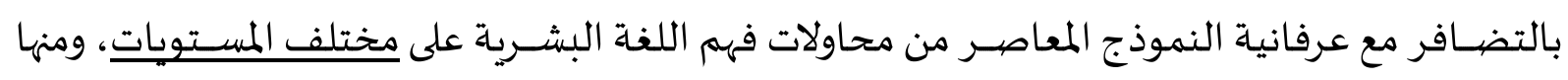
البلاغي لأهميته القصـــوى، وقد كان القرطاجني بارعا في الإشــارة إلى كثير من المبادئ الموجهة للفههم بهذا

الخصوص.

والملاحَظُ عموما على المشـروع البلاغي العربي الكلاسـيكي أنها يتصـف بالعمومية، فموضـوع البلاغة العربية القديمة يشــمل الخطاب الاحتمالي بنوعيـه: التخييلي الشـــري والتداولي الخطابي، رغم أن التخييل هو

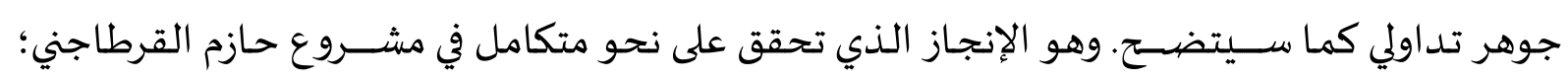
حيث البلاغة هي "العلم الكلي" (1). وبروز قيمة القصيدية بالنسبة للذوات المتخاطبة في النص الشعري يُدخل النص إلى مجال التد اوليات، وهو مجال شاسع يسمح بالقول إن هناك تداولية بلاغية ، إلى جانب التداولية اللسانية والمنطقية والفلسفية (2).

(1) يمكننا عد عمل أبي هلال العسكري "الصناعتين" من أولى المحاولات التي سعت إلى إقامة صرح بلاغة عامة تتسع للمنظوم والمنثور ، كما

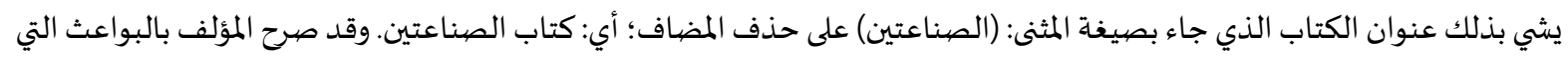

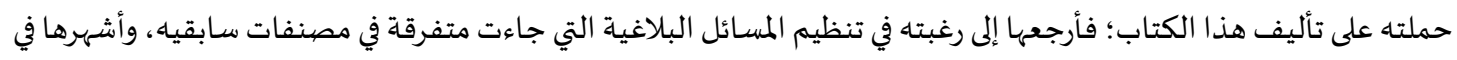
الموضوع كتاب "البيان والتبيين" للجاحظ. لهذه الأسباب يقول العسكري:

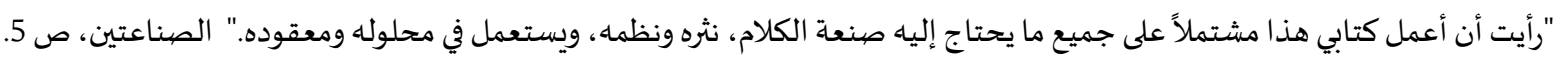

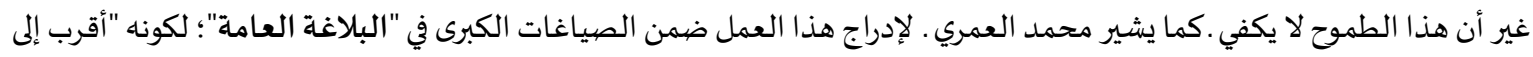

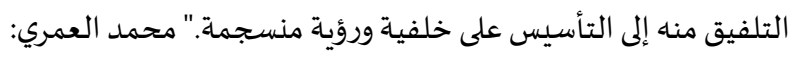

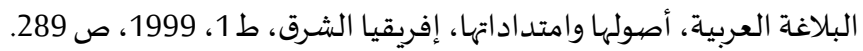

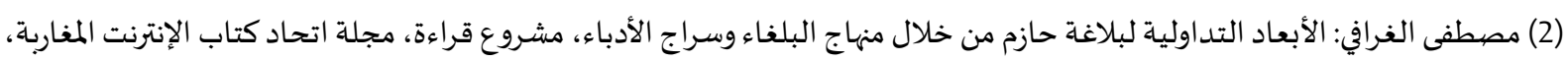




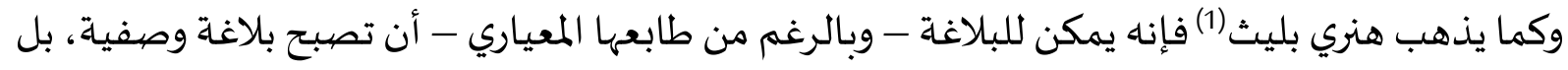

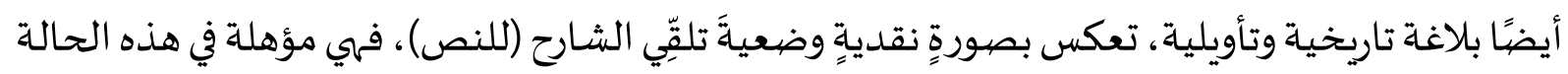

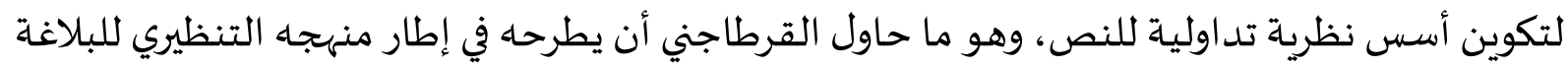

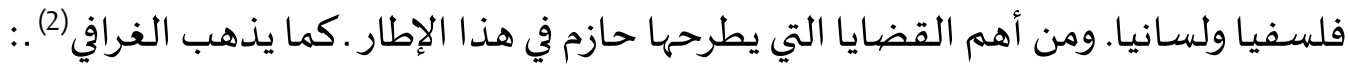
أ - إلحاحه على وظيفية النص الشعبري، بالنظر إلى مقاصديد منجزه.

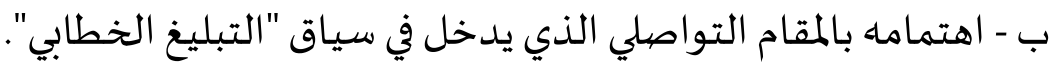

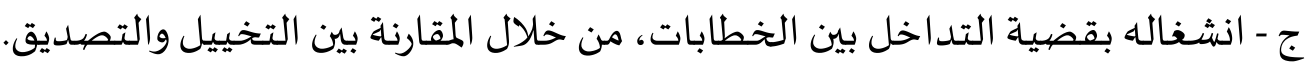

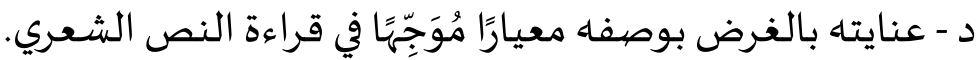

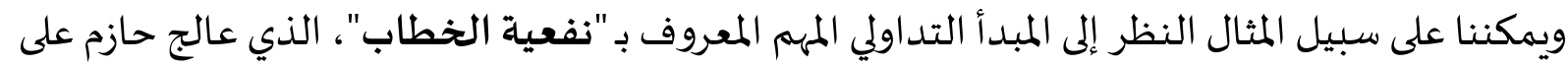

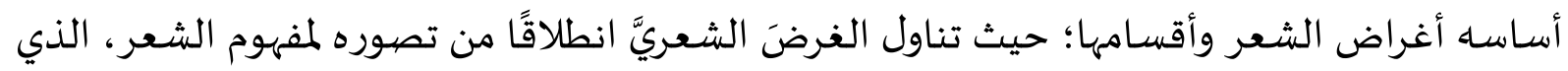
هو تخييل يتقصد التأثير ، وعلى هذا الأساس رفض تقسيمات البلاغيين السابقين لأغراض الشعر، لأنها -

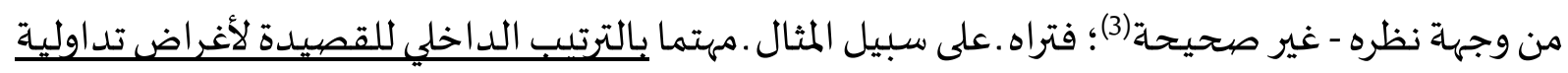
وجمالية.كما سأركز على نقطة هاية القصيدة تحديدا [ الانتهاء ] عندما نتناول الأنظمة الدلالية والإشارية

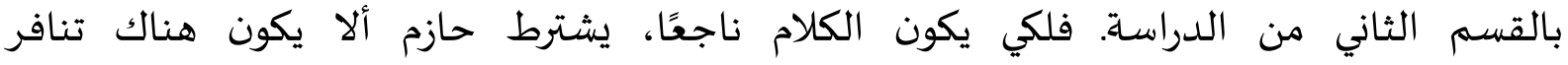

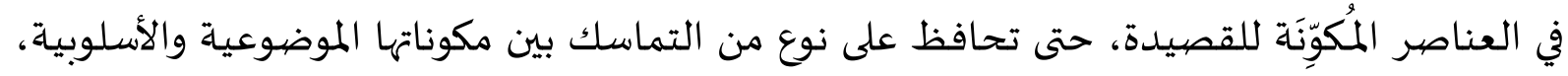

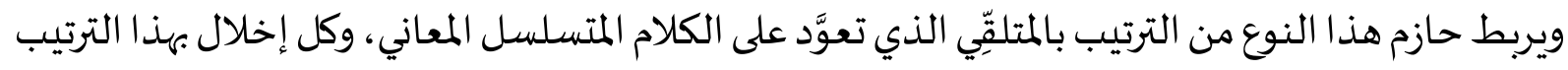

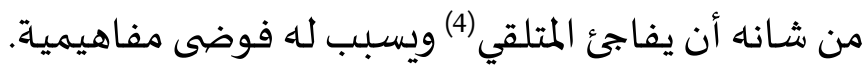

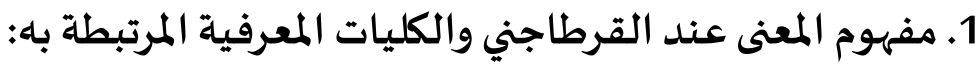

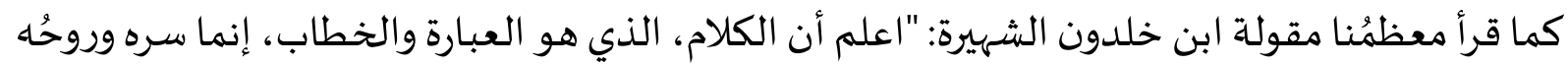

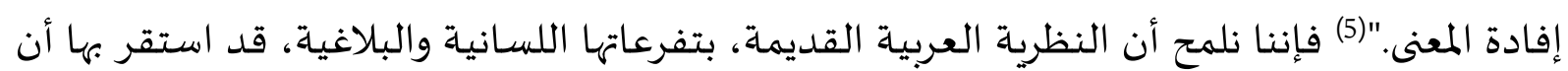

(1) هنريش بليث، البلاغة والأسلوبية .. نحو نموذج سيميائي لتحليل النص، ترجمة محمد العمري، إفريقيا الشرق، ط1، 1999، ص 29.

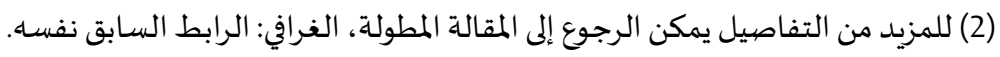

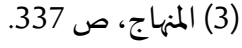

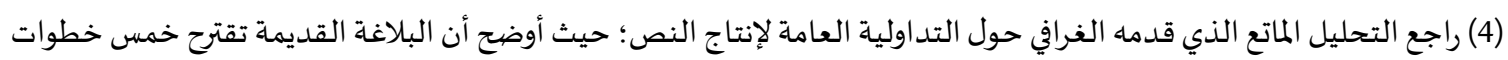
متتابعة زمنيا، تمثل مراحل بناء النص، وهذه الخطوات الخات الخمس - حسبما استخلصها بارت الفارت - هي:

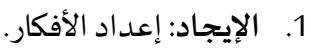

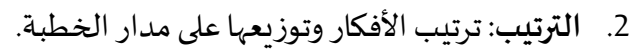
3. العبارة: الصياغة اللفظية البليغة (وجوه الزخرفة). 4. الإيماء: استخدام الحركات والإشارات (مسرحة القول).

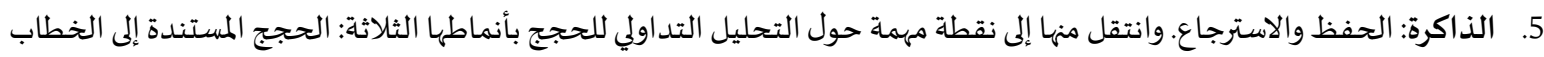

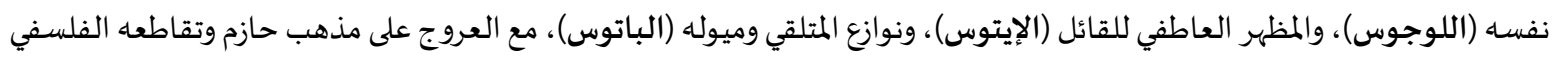


المعاني متقدمةٌ أنطولوجيَّا على الألفاظ، وستأتي تفاصيل مهمة حول عرفانية هذه القضية في هذا القسم من الدراسـة. وقد تنبه القرطاجني إلى جوهر فهم الأغراض الشعرية، مغايرا لما سبقه من العلماء، ومتأثرا بترجمات أرسطو

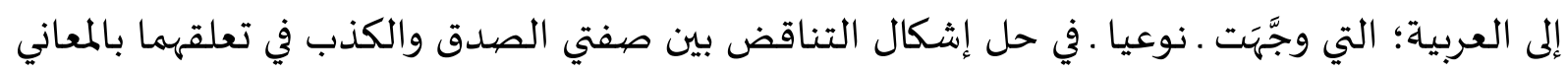

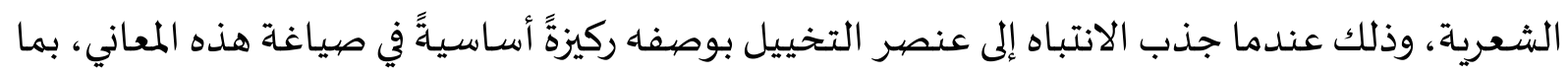

يُخرج هاتين الصفتين من المعايير التقييمة المعتبرة (1).

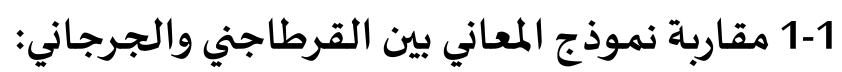
لقد تطورت قضية (المعاني الأُولَ) و(المعاني الثواني) تطورا كبيرا بين علمين كبيرين من أعلام البلاغة العربية العربية الكلاسيكية، هما عبد القاهر الجرجاني (ت 471 هـ) وحازم القرطاجني (ت 684 هـ)، رغم تباعد المسافتين:

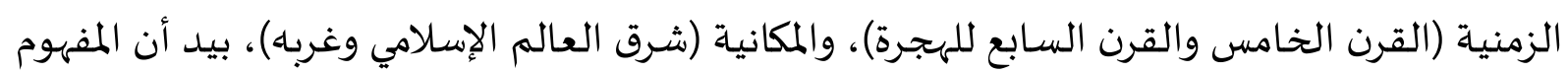

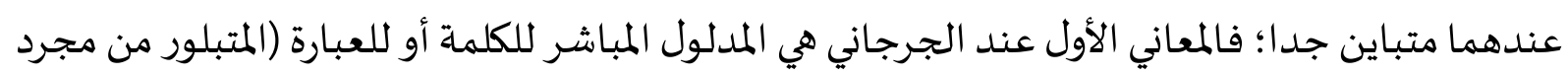
الصوت المسموع أو المعنى الوضعي)، والمعاني الثواني هي التي تُفهم من المعنى الأول؛ أي على ضيوء هذا المعنى،

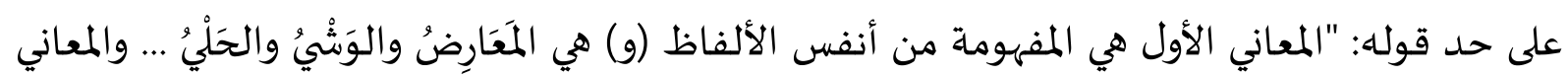

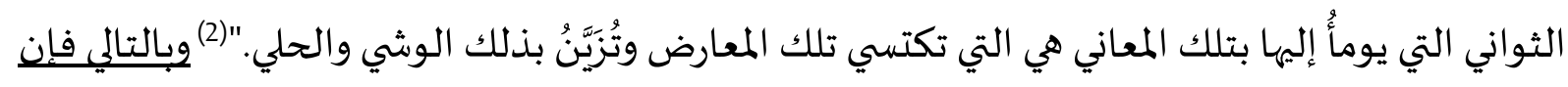
المعاني الثواني عند عبد القاهر هي الأصل، وهي المقصيودة من التعبير، وهي التي من أجلها تكونت ونشأت

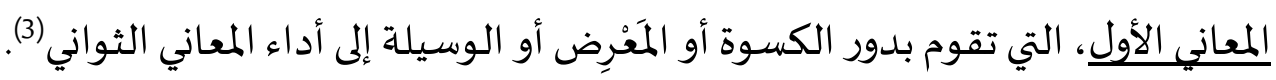

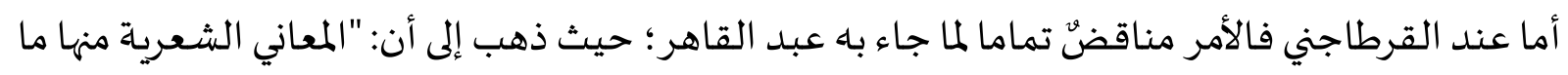
يكون مقصودا في نفسـا بحسب غرض الشعر، ومعتمدا إيراده، ومنها ما ليس بمعتمد إيراده، ولكن يورد

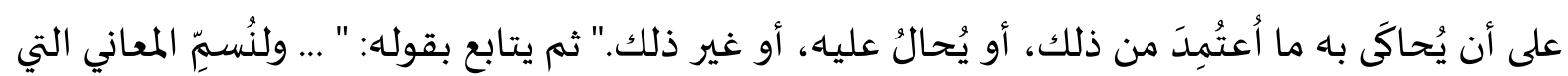

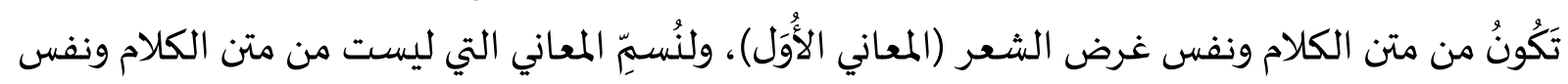
الغرض ولكنها أمثلة لتلك أو استـلالات عليها أو غير ذلك، لا موجِبَ لإيرادها في الكلام غير محاكاة (المعاني

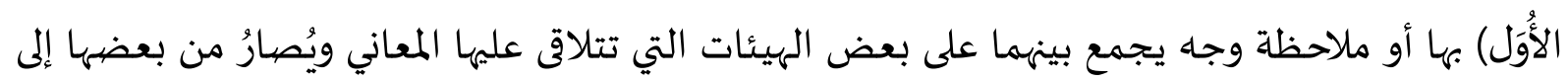

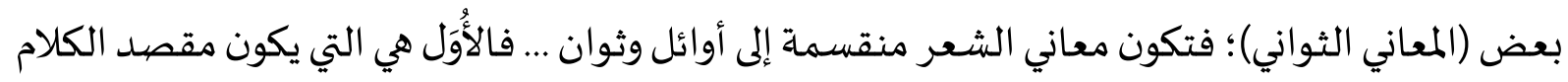

(1) للمزيد من التفاصيل: ابن سينا: فن الشعر، ضمن مجموعة ترجمات الكتاب، تحقيق عبد الرحمن بدوي، نشر نهضية مصر، ط1619،

1953، ص 161 وما بعدها.

(2) عبد القاهر الجرجاني: دلائل الإعجاز في علم المعاني، تحقيق أبي فهر محمود شاكر، طبعة مكتبة الخانجي، القاهرة، ط3، 1992، ص ص ص

.264-263

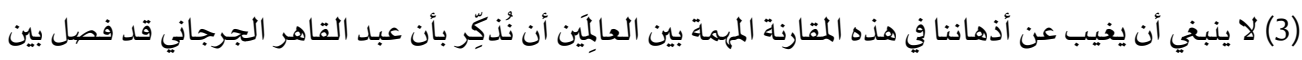

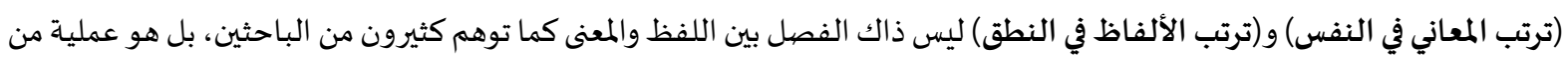

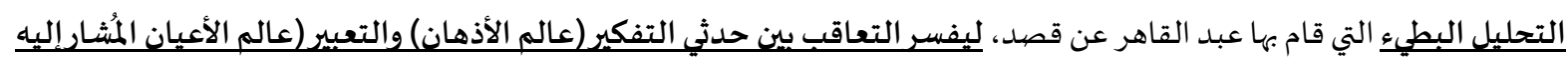

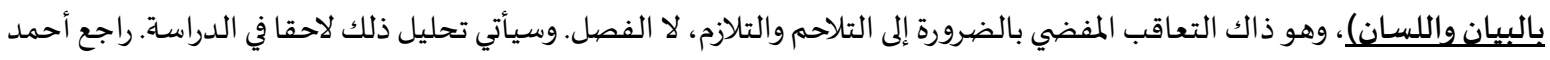

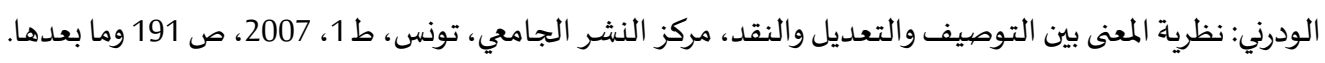


وأسلوب الشعر يقتضيان ذكرها، وبنية الكلام عليها، والثواني هي التي لا يقتضي مقصد الكلام وأسلوب

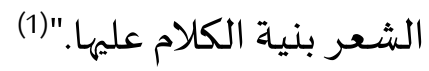
وربما يكون السبب في هذا أن القرطاجني قد بدا مشدودا أحيانا إلى ابن سينا في تعريف الشعر ابتداءً

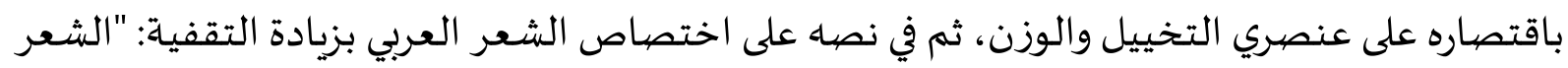

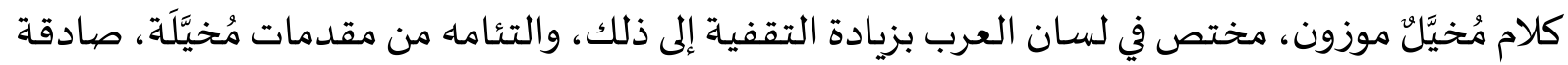

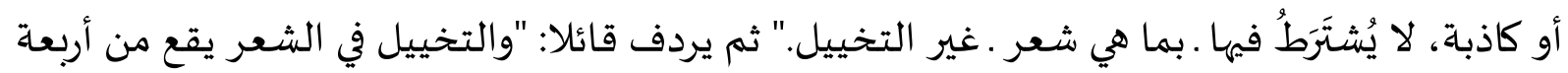

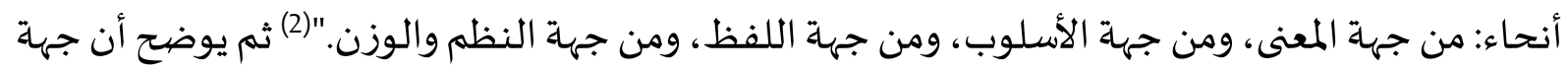

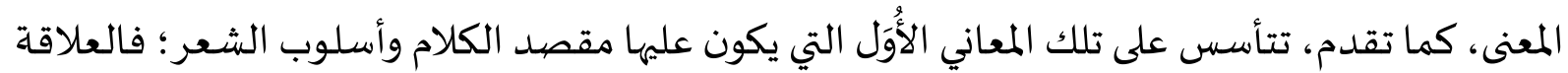

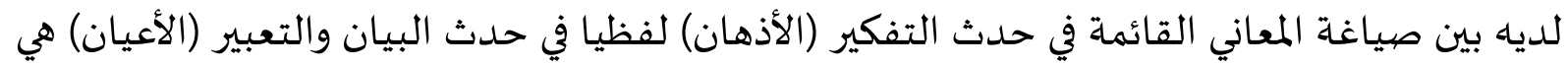

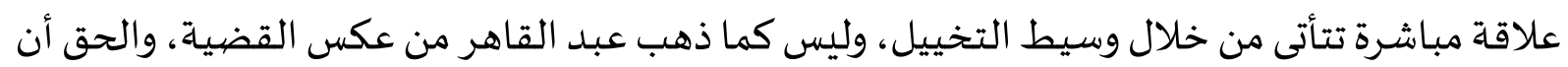

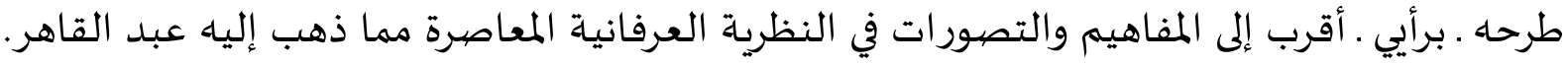

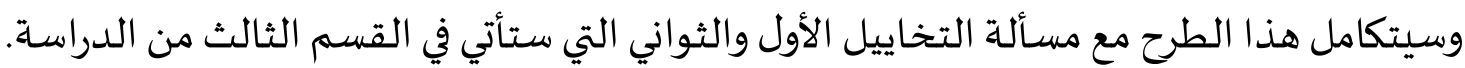

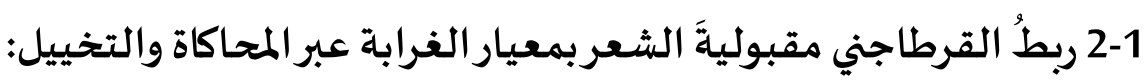

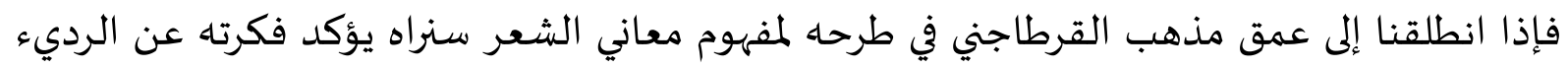

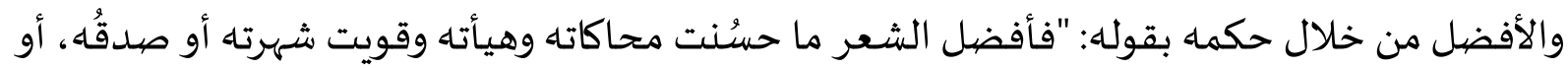

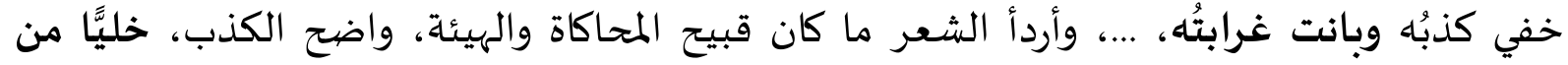

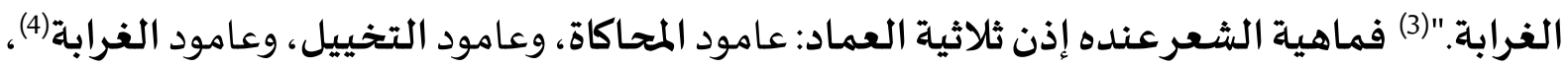

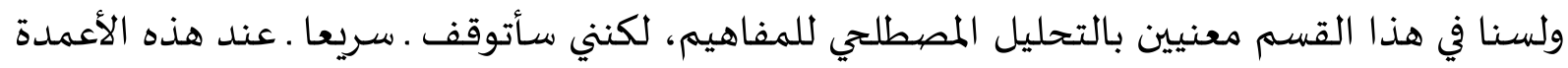

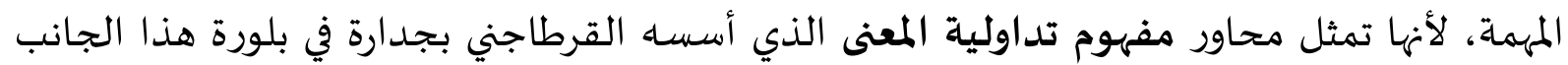

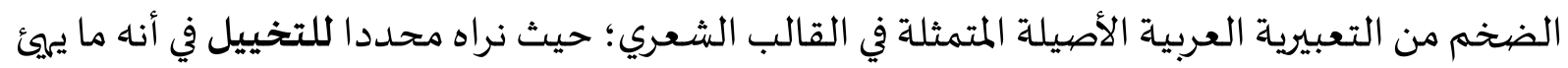

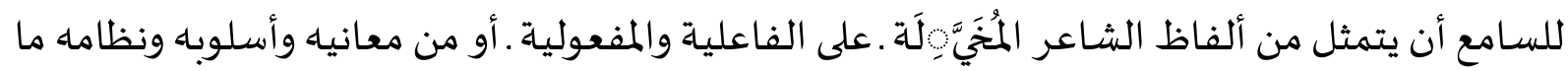

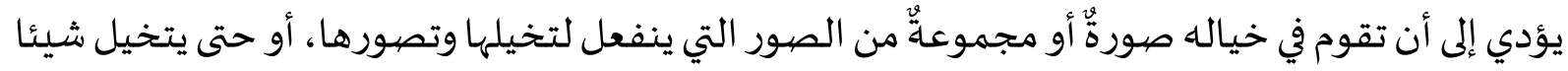

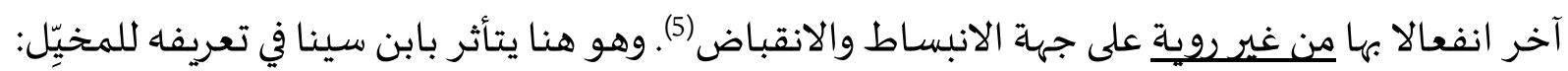

(1) منهاج البلغاء، ص ص 23-24. وراجع تعليق الدكتور عبد الحكيم راضي على هذا وتفاصيل نقده: دراسات في النقد العربي (التاريخ -

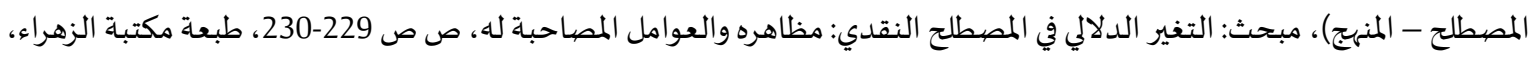

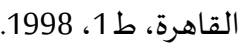
(2) (2) منهاج البلغاء، ص 89.

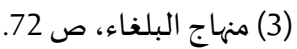

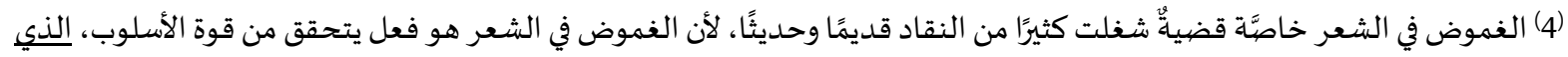

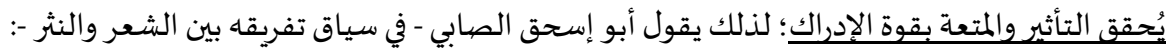

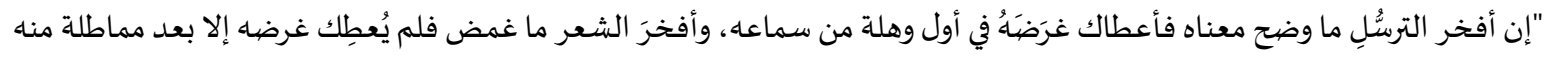

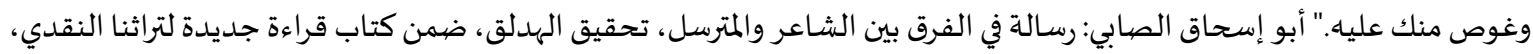

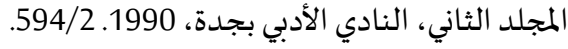
(5) (5) راجع النص في المنهاج، ص 89. 
"هو الكلام الذي تذعن له النفس فتنبسط بالأمور أو تنقبض عن أمور عن غير روية وفكر واختيار."(1) أما

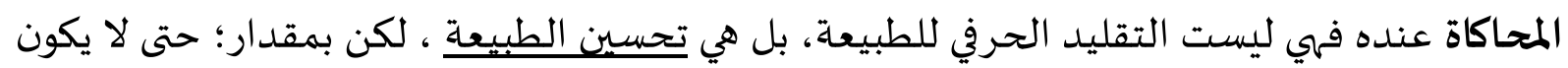

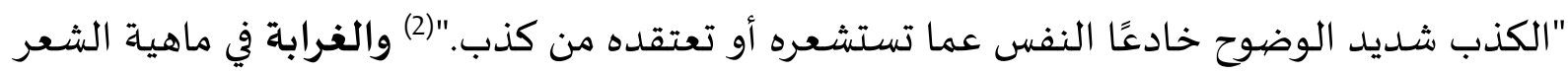

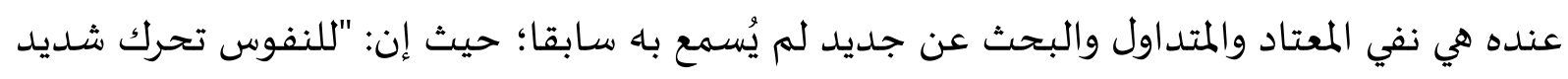

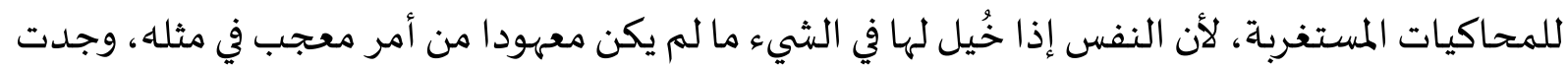

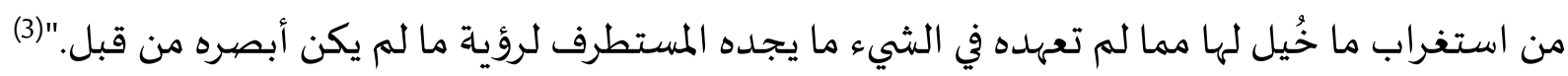

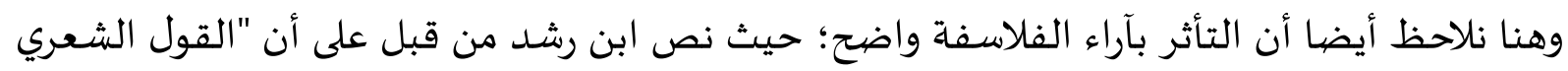

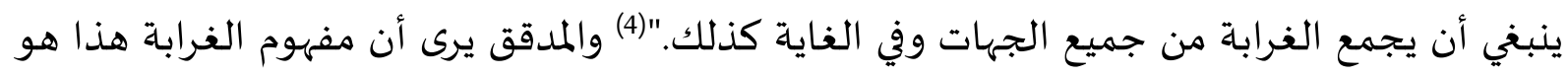

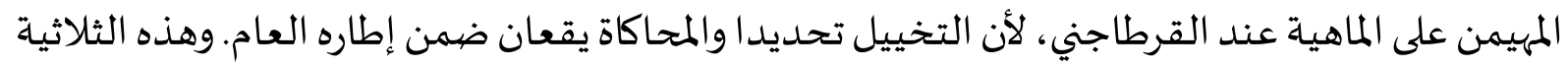

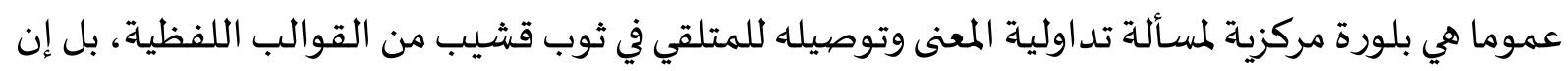

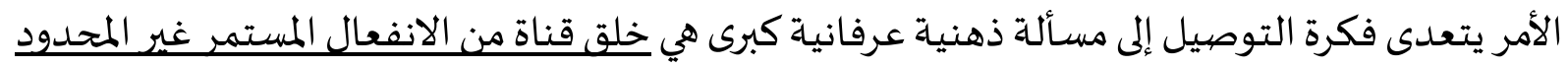

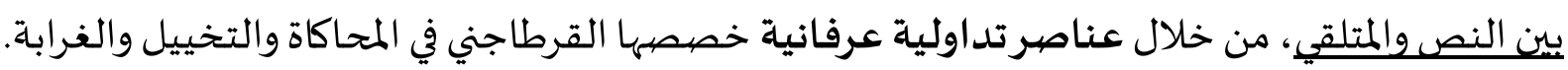

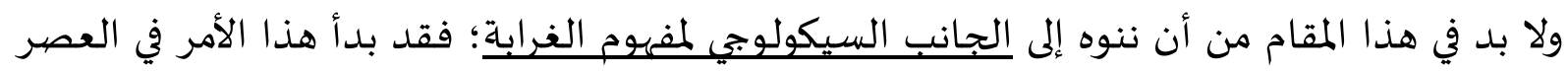

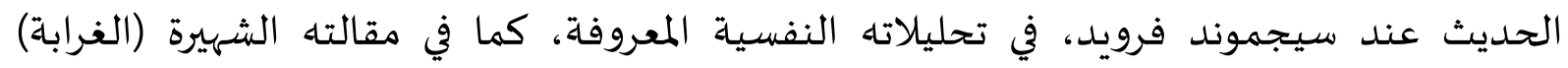

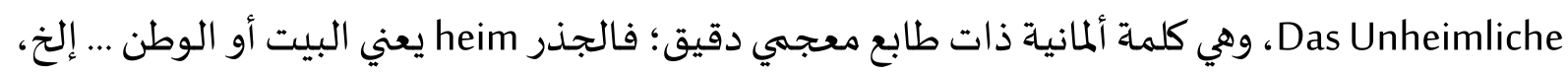

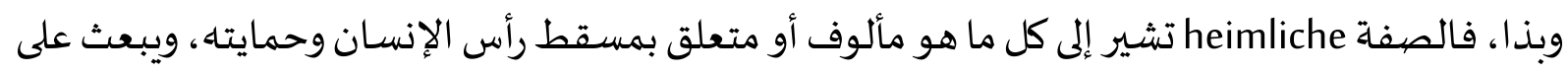

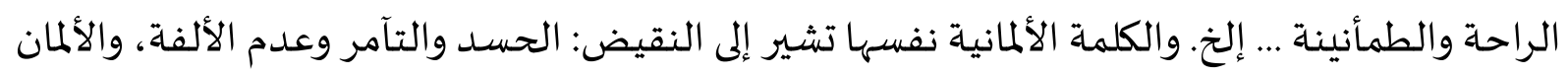

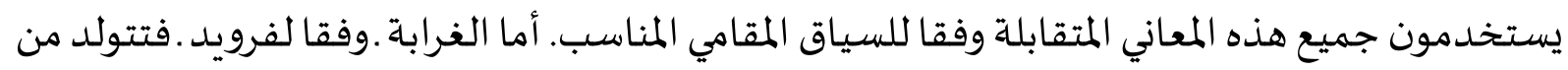

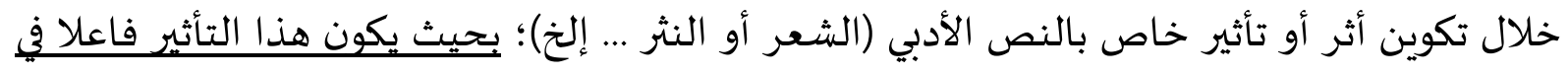

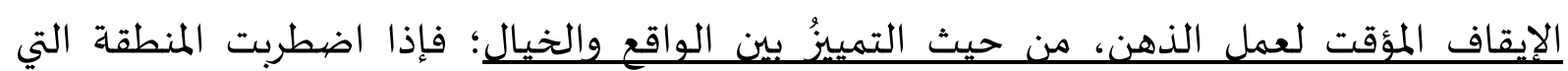

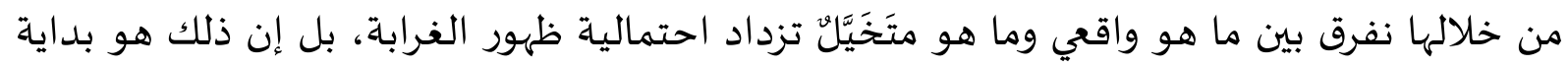

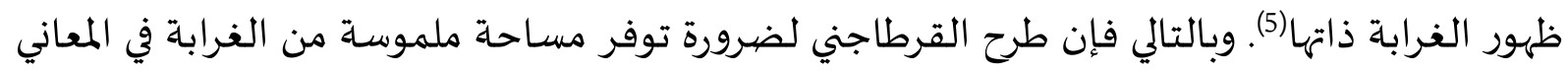

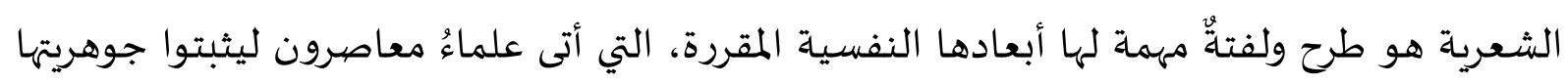

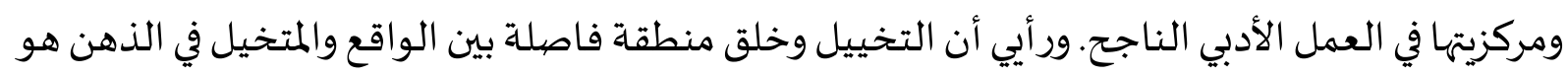

(1) أرسطو طاليس: فن الشعر، ترجمة عبد الرحمن بدوي، دار الهضية المصرية، القاهرة، ط1، 1954، ص 161.

(2) (2) المنهاج، ص 72 (1) (3)

(3) (3) المنهاج، ص 96.

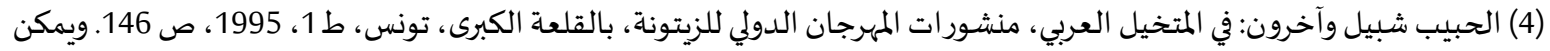

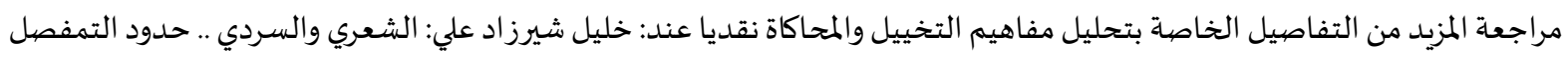

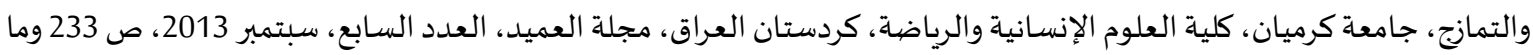


ما يعطي للشعر خصوصيته التعبيرية المتفردة، خصوصا في حالة استخدام المعجم العربي واشتقاقاته وصيغها وأسـاليبه الخصبية، وإلا كانت اللغة مباشرة غير مثيرة للاشتغال الذهني على أي مستوى كان. والحق أن اللسانيات العصبية تؤكد في هذا الجانب العرفاني مسألة أن الدماغ البشري في عمله العام هو دماغ استعاري مزجي، يخلط العناصر الوجودية خلطا فريدا ويمزجها مزجا عجيبا، لأجل أن يبلور المعاني

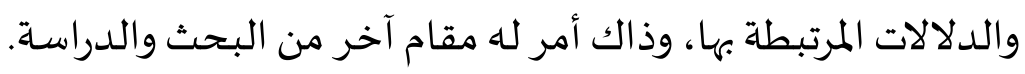
1-3-1 المفهوم العرفاني التداولي للمعنى عند القرطاجني:

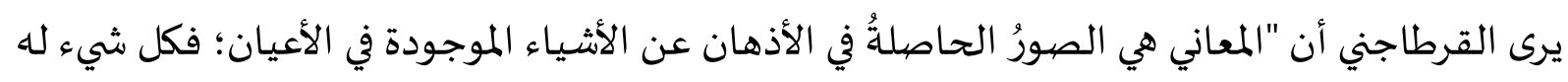

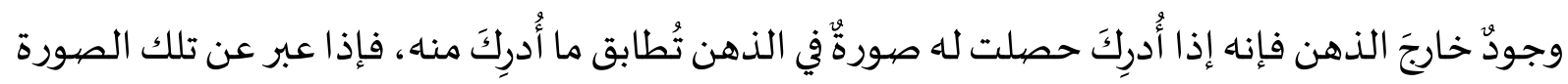

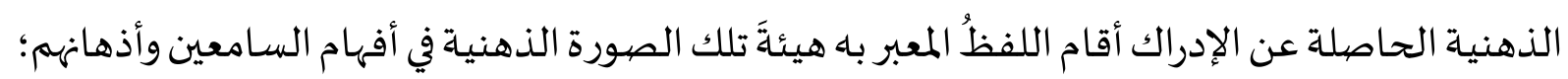

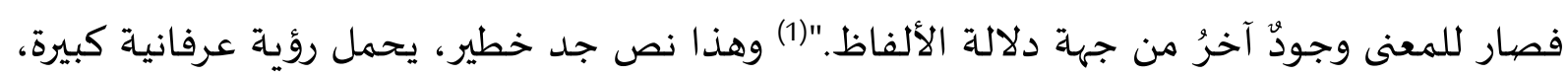

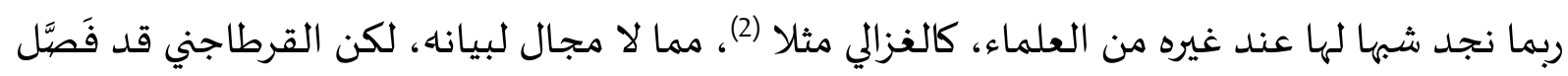
وأفاض؛ إذ انصب اهتمامها على كيفية تشكيل الصورة وطريقة انتظامها؛ حيث تحمل الصورة عنده معنى مئى الاستعادة الذهنية لمدرك حسي غير موجود في الإدراك المباشر، ومن ثم تصبح الصهورة عنده ذلك

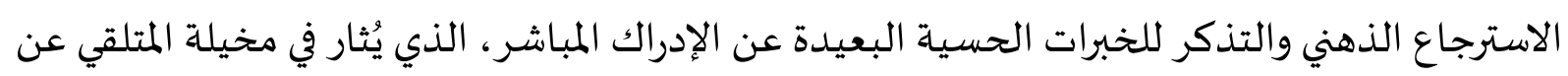
طريق المنبهات اللفظية الحاصلة في الفعل اللغوي الأدبي، ويؤكد ذلك قوله: "ومحصيول الأقاويل الشعرية الشية تصوير الأشياء الحاصلة في الوجود وتمثيلها في الأذهان على ما هي عليه خارج الأذهان (عالم الأعيان) من حسن أو قبح حقيقة."(3) فمادة المعنى إذن هي الطبيعة الخارجية المنطبعة في ذهن الإنسان، وبالتالي فإن إنان

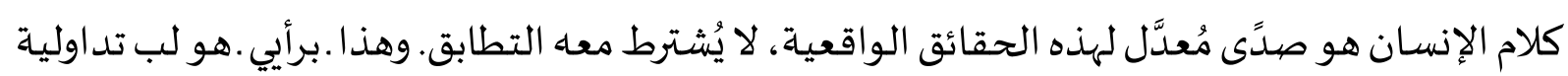
المعنى وأصالته.

مدار النظر بهذا التوجاء هو مسألة الترتيب بين (الموجودات) و(المعاني) و(الصور) الحاصلة عن تلك الموجودات؛ على اعتبار أن "البحث في موضوع المعاني يفترض سلفا هذا الوجود، بقطع النظر عن النقاش

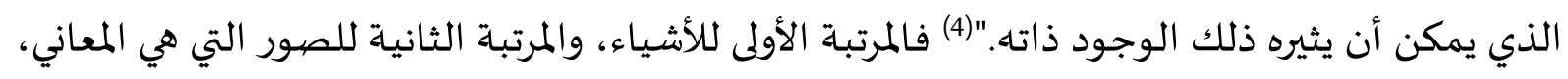
وهذه ليست أصلية، وإنما متحصلة عن التعقل والتفهم والإدراك (الاشتغال الذهني العام)، والأمر شبياء بما طرحه ابن سينا؛ فالصورة عند ابن سينا هي الشيء الذي تدركه النفس الباطنة والحس الظاهر معا،

(1) (1) المنهاج، ص 169.

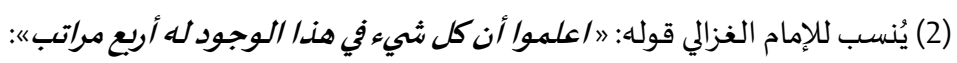

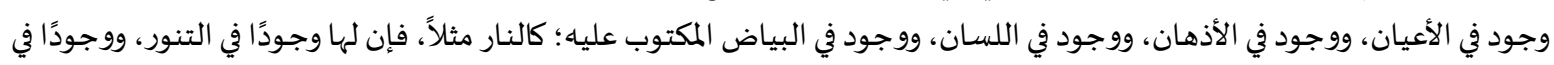

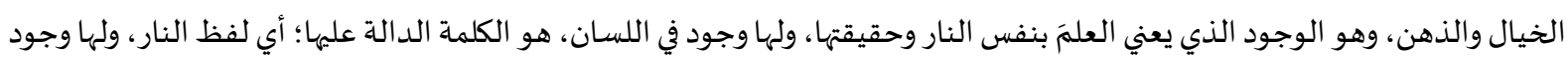

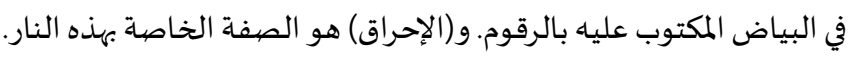

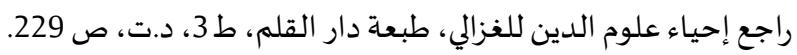

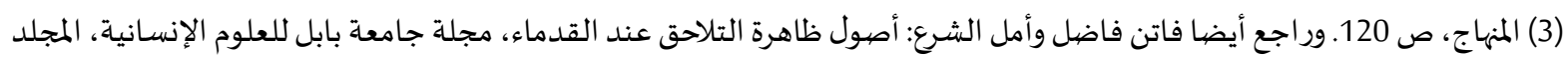

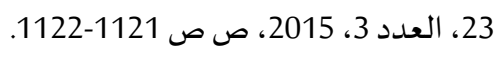
(4) حمادي صهمود: نظرية المعنى في التراث العربي وأثرها في فهم وظيفة الصهورة، ضمن كتاب (في نظرية الأدب عند العرب)، النادي الثقافي

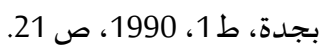


لكن الحس الظاهر يدركه أولا ويؤديه إلى النفس، وذاك يجعلنا نفهم أن المعنى ليس هو الشيء ذاته، كما القرطاجني

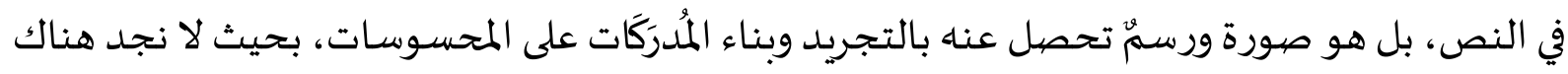

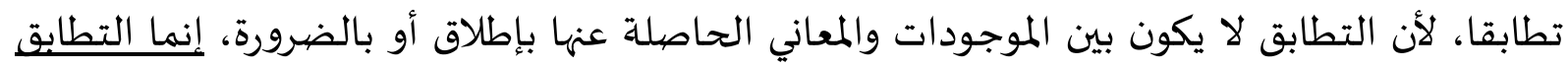

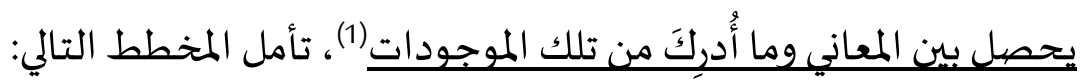

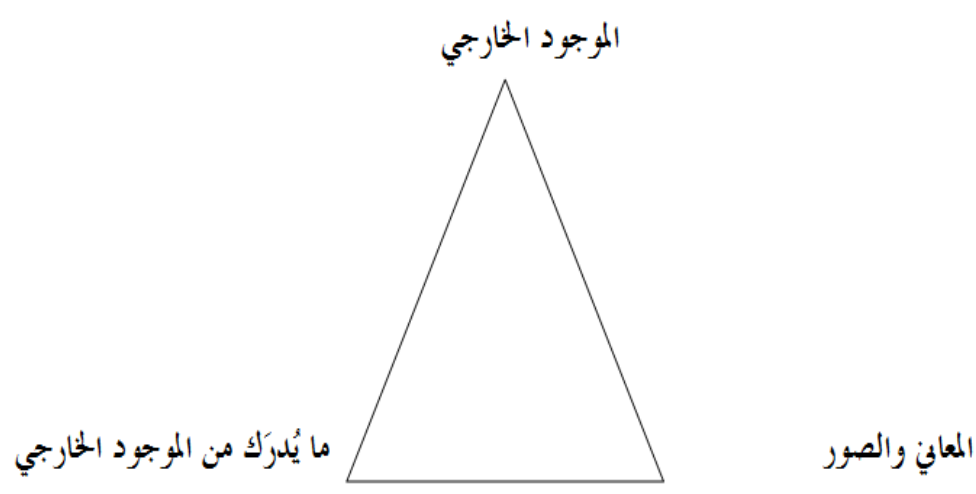

وبذلك يصبح المعنى صيرورة للشيء وإعادة صياغة له، بل يصبح وجودًا ثانيا مغايرًا للوجود الأول. وربما

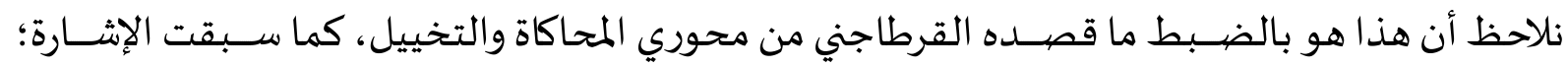

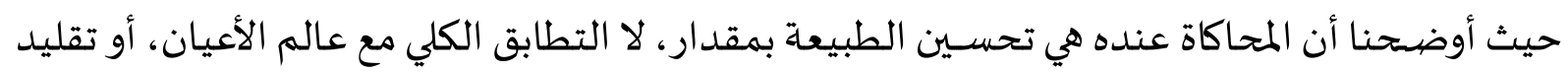

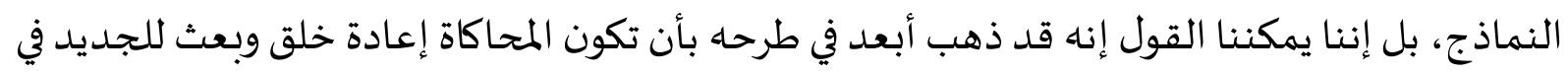

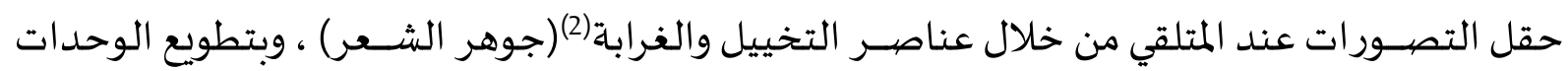

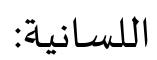

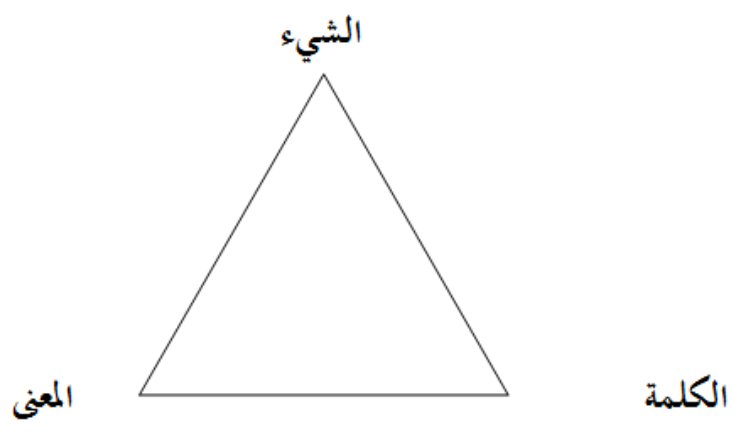

(1) للتفاصيل: حمادي صمود، المرجع السابق، ص 21 وما بعدها.

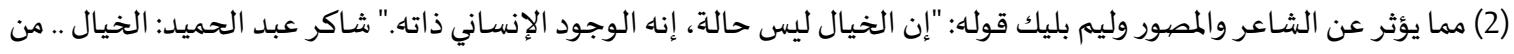

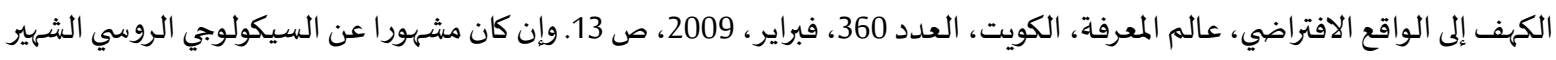

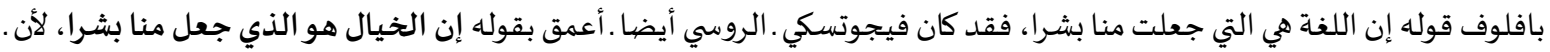

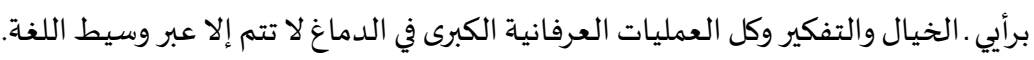


المعاني إذن هي حاصل انعكاس جانب من ماهيات الأشياء في النفس، فهي ليست ذات الأشياء، بل هي صُورٌ

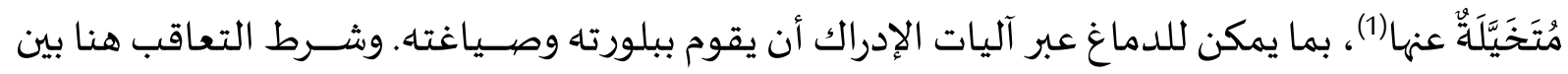

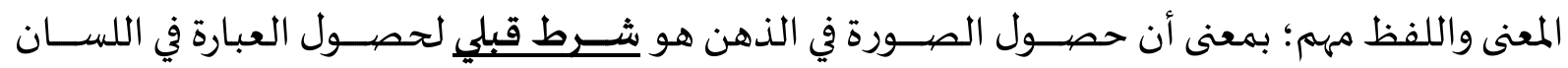

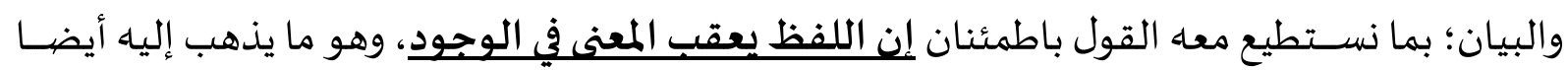

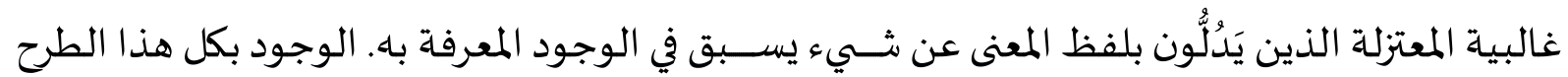
إذن يأخذ الصهور التالية (2).

\begin{tabular}{|c|c|c|c|}
\hline الوجود الرابع & الوجود الثالث & الوجود الثاني & الوجود الأول \\
\hline الكلمات مكتوبةً & الكلمات منطوقةً & المعاني & الأشياء \\
\hline
\end{tabular}

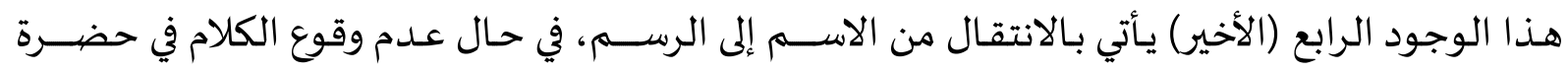

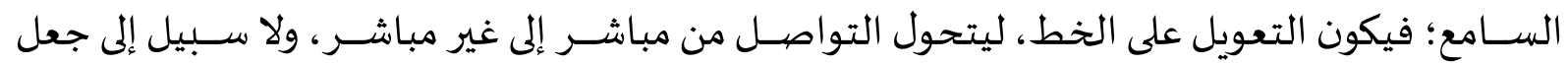

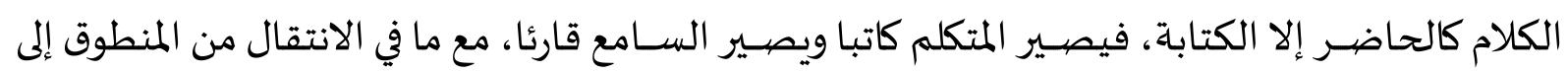

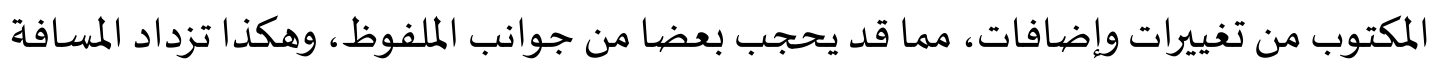

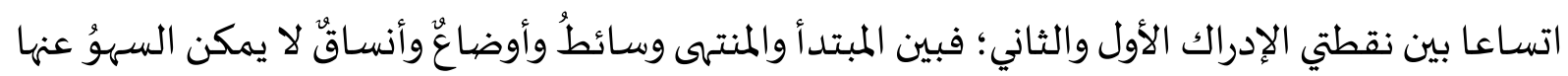

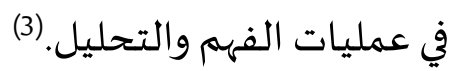

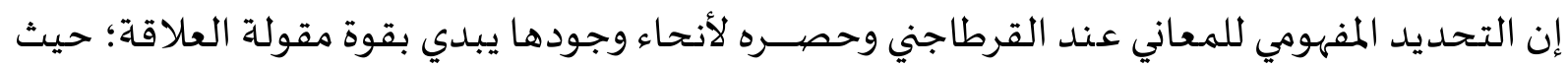

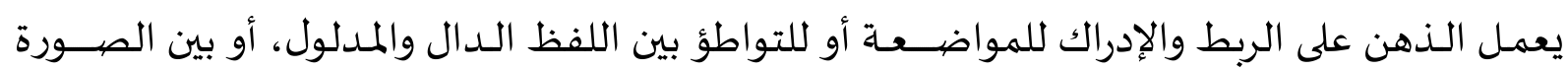

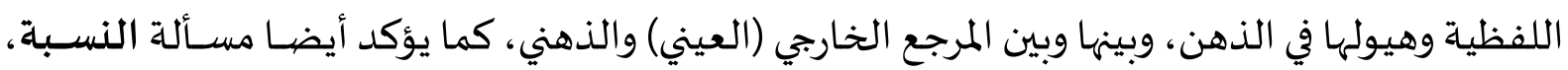

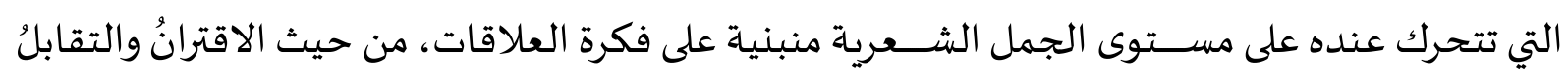

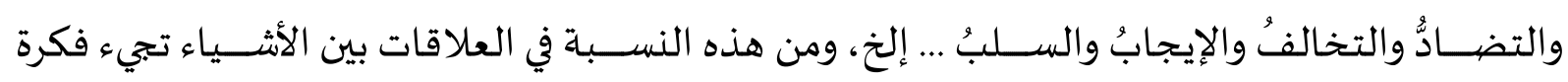

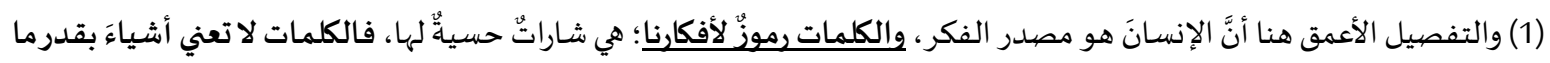

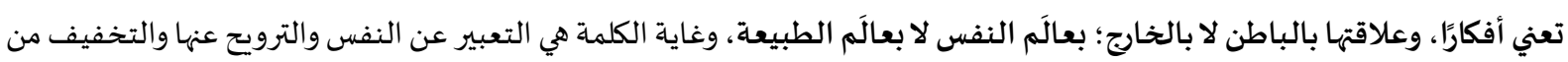

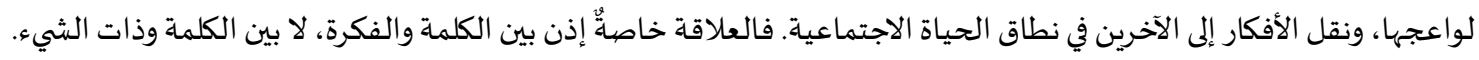

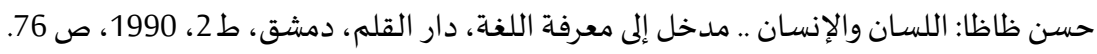

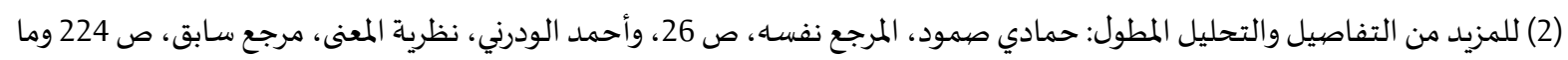

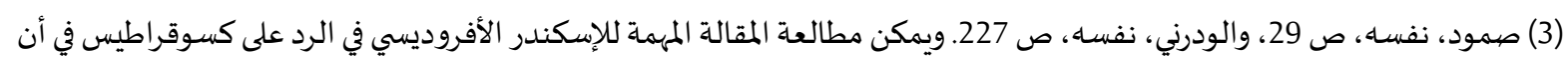

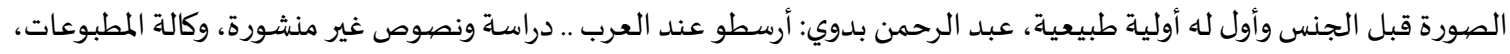

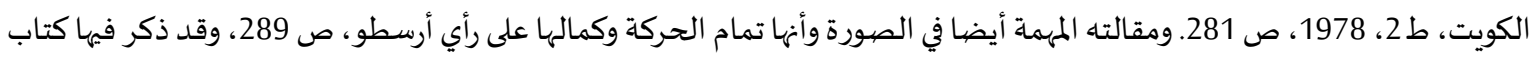

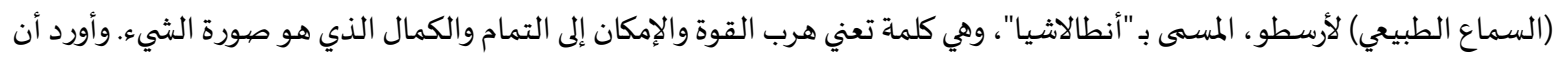

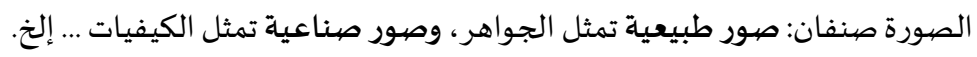




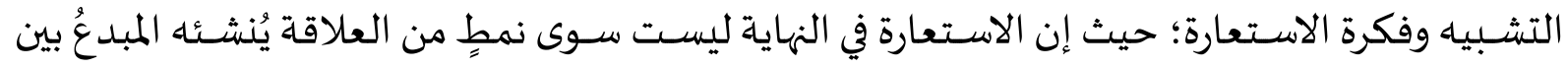
الأشـــياء(1)، أو بعبارة عرفانية: هي ناتج عمليات مزج بديعة يقوم بها الدماغ لأجل فهم أنطولوجيا الأعيان. كما سـيأتي بعد قليل توضـيح مسـألة ما يُعرف بالمعاني الذهنية التي ليس لها حيز في عالم الأعيان، وقد برع القرطاجني في توضيحها.

1-2-3-1أ الجدلية الفلسفية حول المحاكاة وتوصيل المعنى وموقف القرطاجني: دون الخوض في تفـاصـيـل تحتـاج إلى صــفـحات طويلة، فمعلوم أن أفلاطون قـد انطلق في بلورتها لمفهوم المحاكاة من نظريته حول المُثُل Theory of Ideas، التي تُعد الأسـاس عنده لتشـكيل نظرية المعرفة عموما،

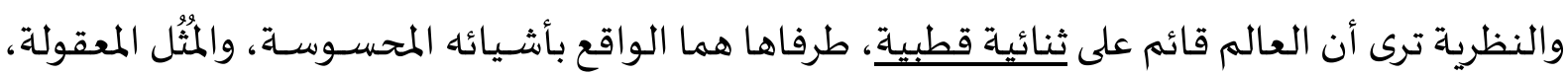
وما بين المحسـوس والمعقول تقوم علاقة معرفية، يجريها الإنســان المثالي، الذي هو الحكيم الفيلسـوف ل... إلخ، وعلاقة المعرفة هذه هي فعل المحاكاة، الذي يمثل الحركة القادرة على التوسـط بين عالم المثل وعالم

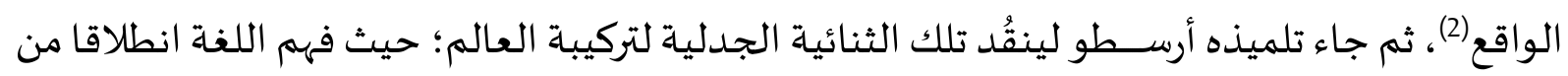

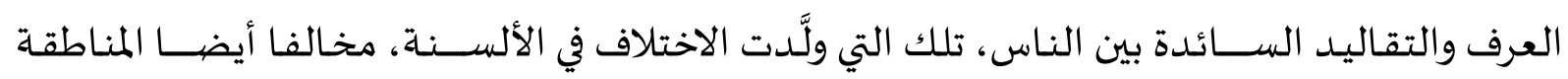
والفلاســفة الرواقيين Stoicism (3)، الذين قالوا إن نظرية المحاكاة الطبيعية هي التي تحكم نشــأة اللغة،

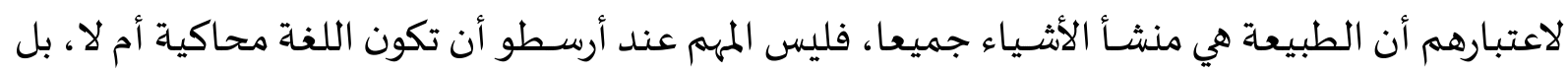

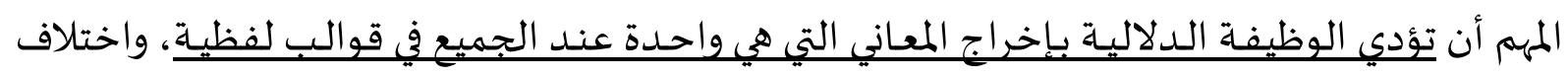
الألسنة لا يعني اختلاف المعاني، بل يدخل في دائرة اختلاف الأسـاليب التعبيرية؛ يقول: " ... وكما أن الكتاب إسئ

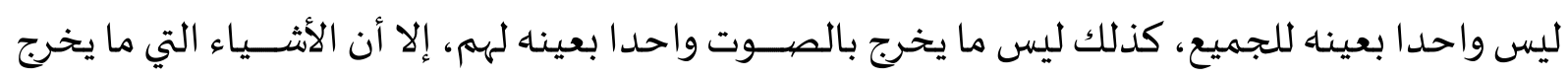

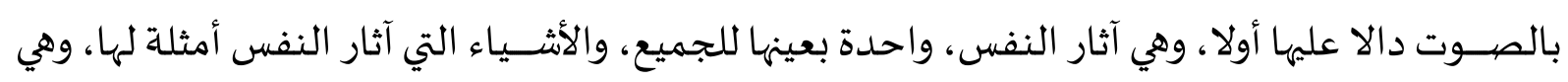

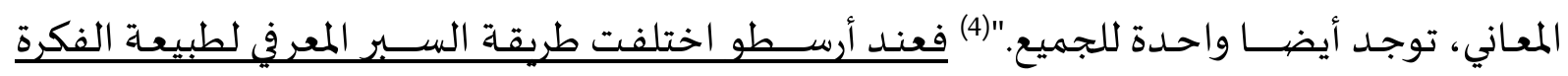

(1) للمزيد من التفاصيل: فاطمة عبد الله الوهيبي: نظرية المعنى عند حازم القرطاجني، المركز الثقافي العربي، ط1، 2002، ص ص 27 وما بعدها. وقد أشارت الكاتبة إلى أن المعنى والنسبة والعلاقة عند القرطاجني هي مسائلُ مهمة حدها حازم بشرط ملاحظة وجوه طبيعة هذه العلاقة،

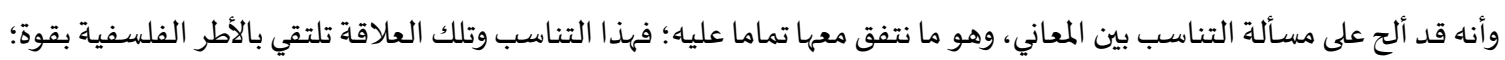
فالعلاقة هي عمل العقل المحض حال ربطه بين التصور والتصديق، وهو أمر بحثه أرسطو ومن بعده، وقد توقف ابن ابن سينا .أكبر من أثروا

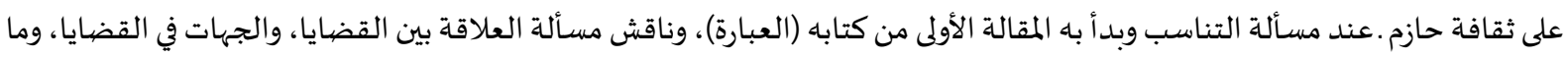

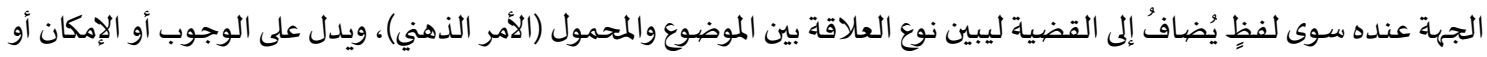

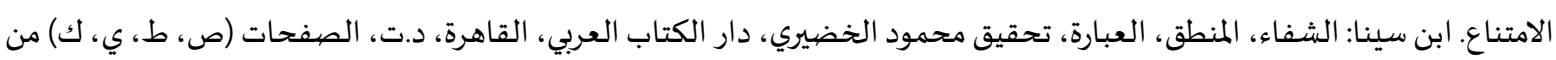

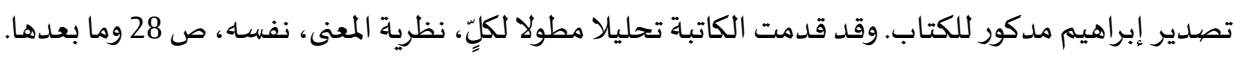

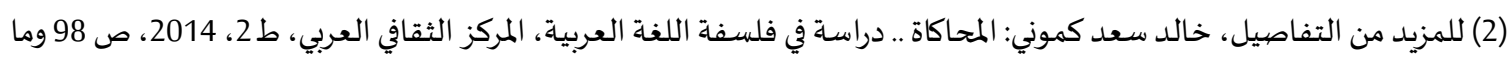

(3) ظهرت فلسفتهم الهللينستية Hellenistic philosophy (نسبة إلى الحقبة الزمنية الثانية للحضارة اليونانية؛ والأولى هي الهيللينية أو

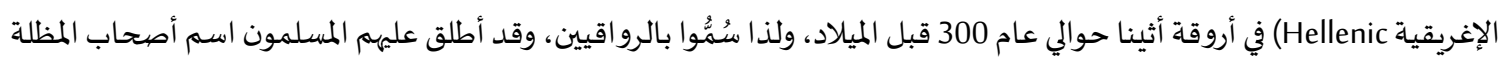

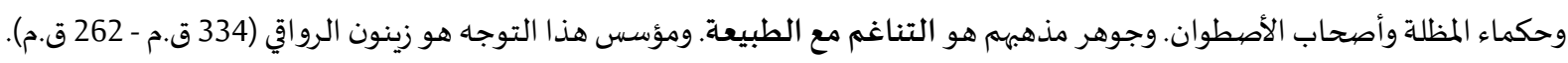

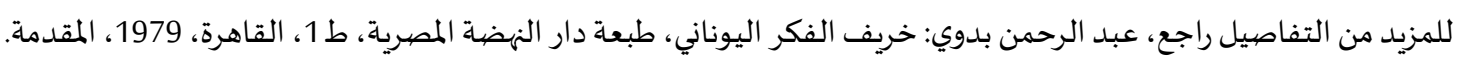
(4) أرسطو طاليس: كتاب العبارة، نقل إسحق بن حنين، تحقيق وتقديم عبد الرحمن بدوي، ضيمن كتاب (منطق أرسطو) الكويت، وكالة

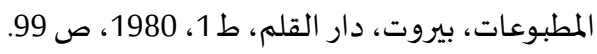


اللغويةٍ؛ حيث إن الأشـياء من حيث وجودُها الطبيعي الواقعي هي التي تقتضي نشـوء العلامة اللغوية؛؛

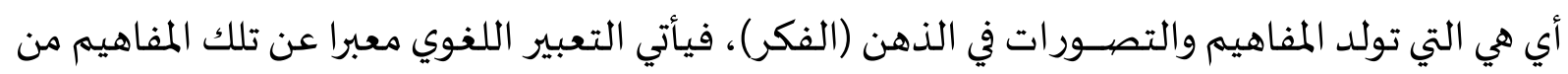
خلال قـالب اللفظ (1). وهنـا نربط بكلام القرطاجني: "إن المجموع ليس لـه نظـام المجموع." وهي عبـارة قـــ

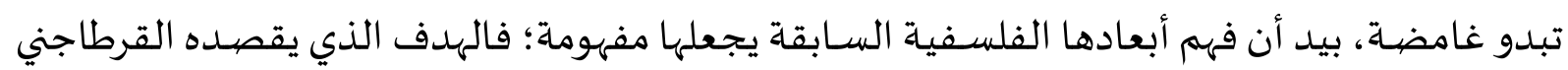
هو تحقيق الوظيفة الدلالية، وهذا لا يكون بالصـوت المنطوق، بحيث يكون دالا بطبيعته على الثـيء، بل يكون عن طريق الاصطلاح والتواطؤ على أن يكون مجموع الحروف، بطريقة معينة، دالاعلى المفهوم المراد

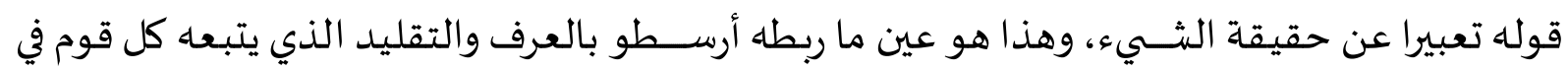
التعبير عن حاجاتهم؛ فاللفظ عند أرســطو والقرطاجني يقول المعنى، لأن هذا المعنى غير مفارق لأشــياء

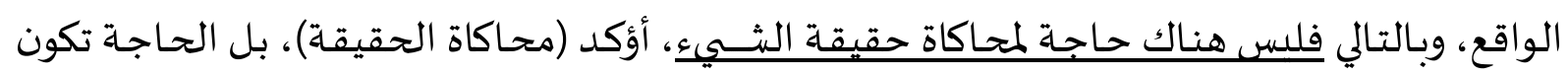

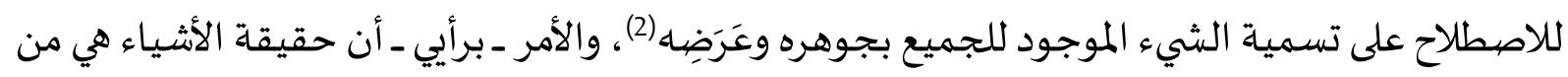

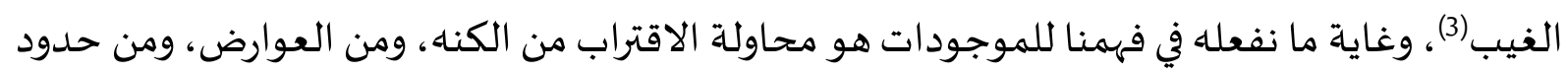

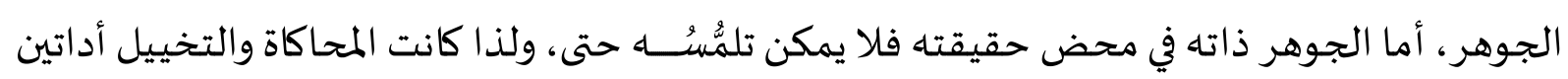

غاياة في البراعاة، فطن إليهما القرطاجني في المسألة التعبيرية الذهنية برمتها.

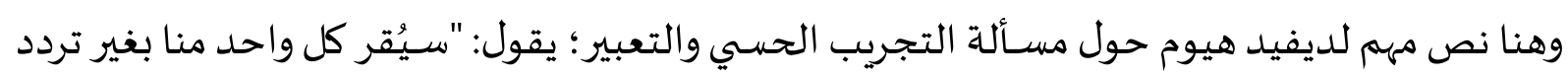

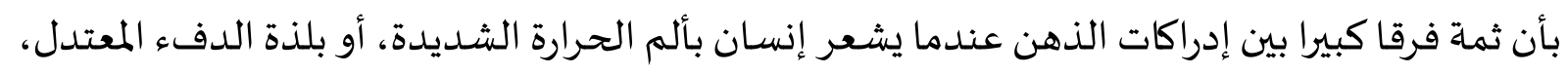

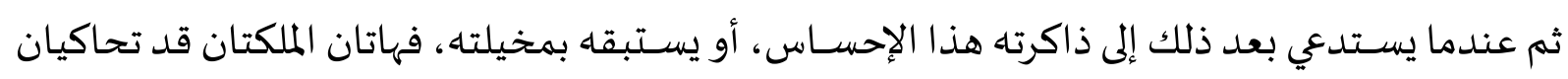

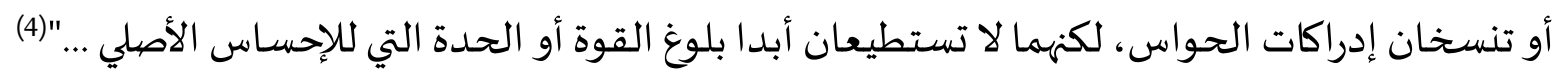

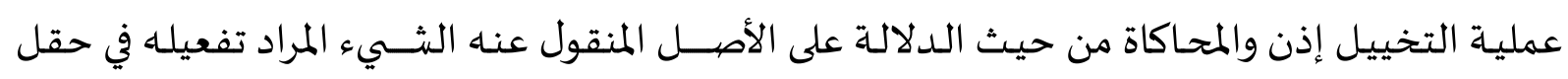

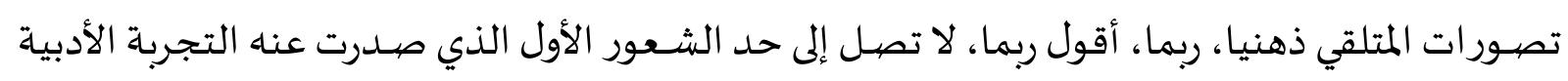

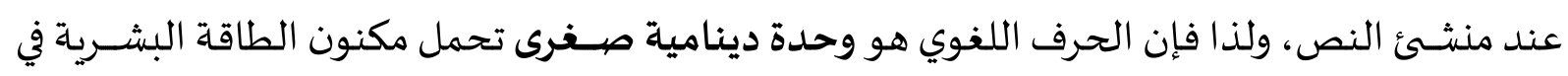

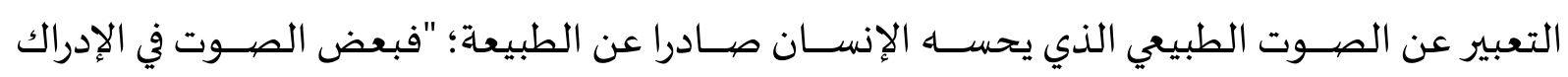
والعقل (وهي عملية تتصـف بالديمومة في أذهاننا) يكفي لاسـعادة الإنسـان تجربته مع الصــوت." وهذا هو

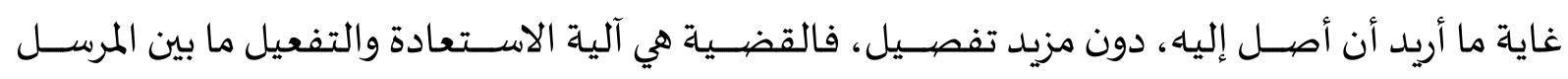

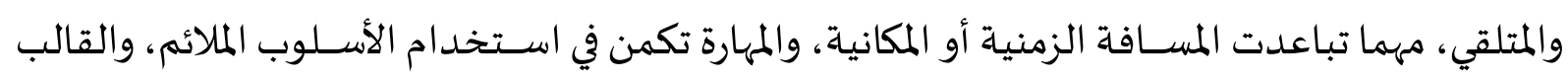

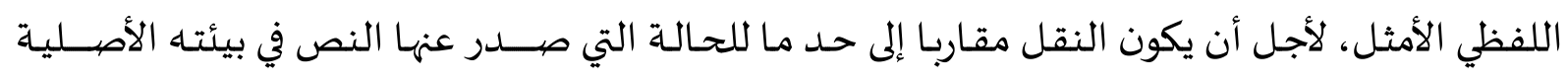

(1) (1) خالد كموني: المحاكاة، نفسه، ص ص أنماض 114-115، بتصرف.

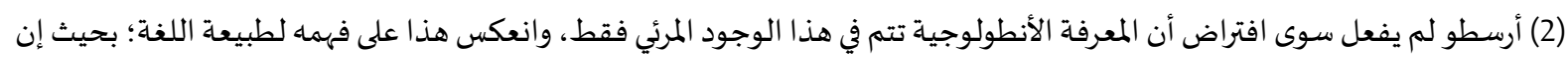

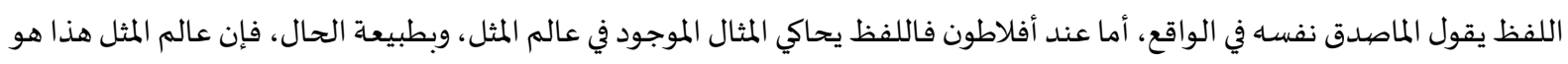

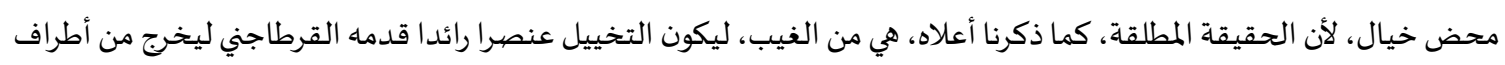

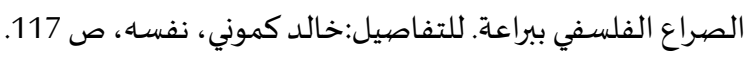

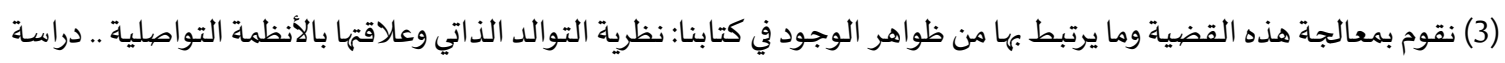
إبستيمية في الطبيعة الكونية، قيد التحرير والنشر. (4) ديفيد هيوم: تحقيق في الذهن البشري، ترجمة محمد محجوب، المنظمة العربية للترجمة، بيروت، 2008، ص 39. 
الطبيعية، بل إن التفاعل قد ينشـأ عنه أنماط جديدة تخلق حالة أخرى أشــــ أو أضـعف، وفق ما يعتمل

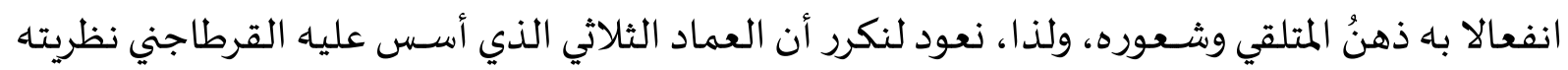

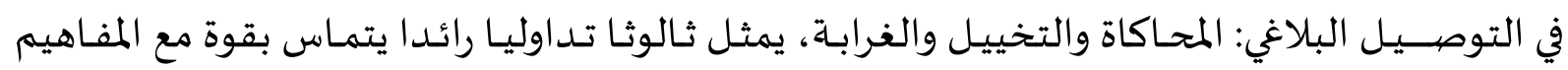

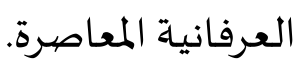

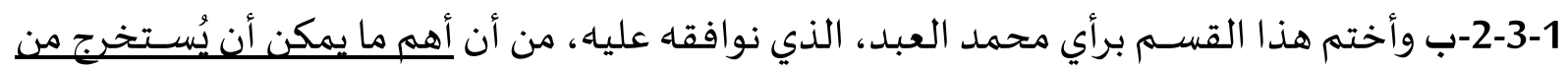

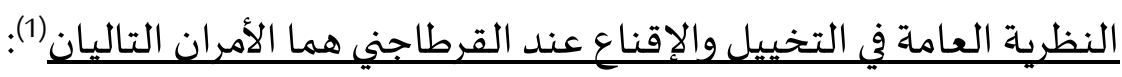
تمييزه بين جهتين للكلام.

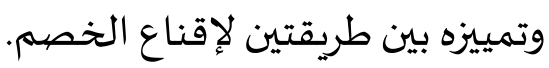

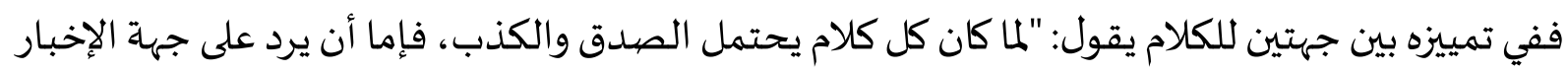

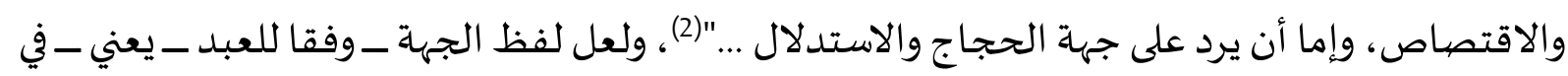

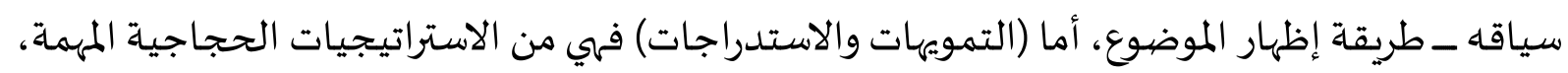

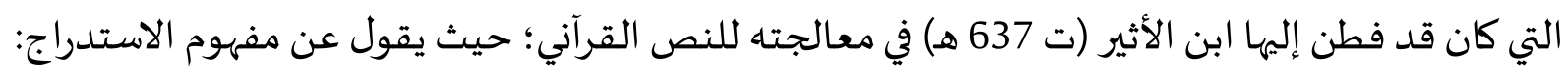

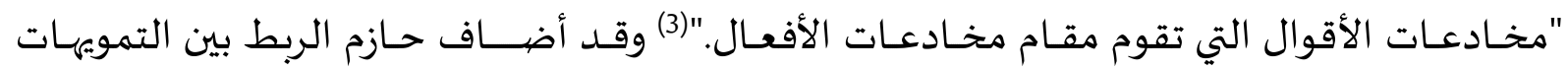

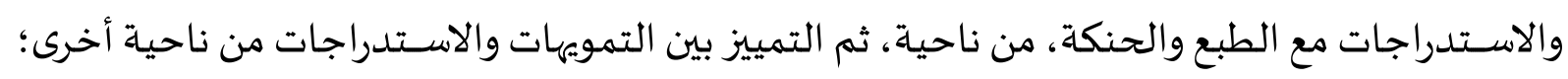

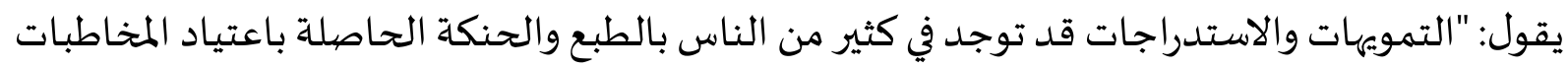

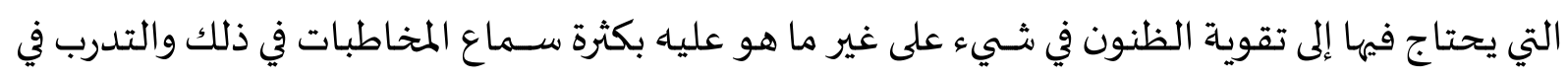

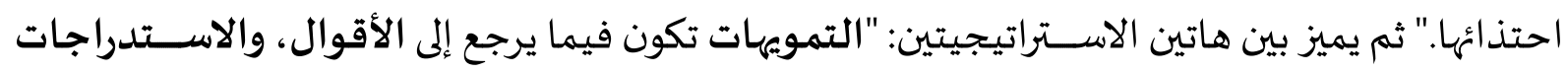

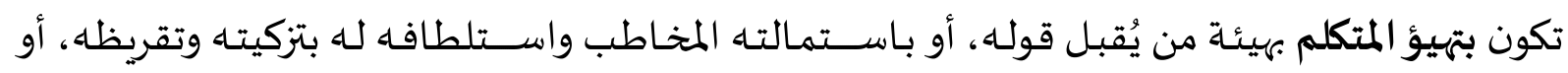

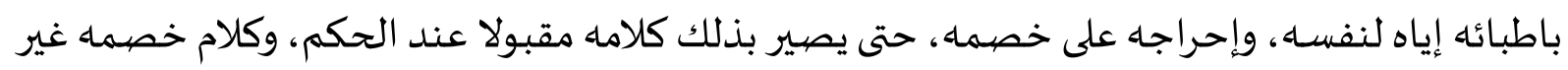

مقبـول."(4)

\footnotetext{
(1) محمد العبد: النص والخطاب والاتصال، المكتبة الأكاديمية الحديثة، القاهرة، ط 1، 2014، ص 153 وما بعدها.

(2) (3) المنهاج، ص ص 63.

(3) ابن الأثير (ضياء الدين): المثل السـائر في أدب الكاتب والشاعر، تحقيق وتعليق أحمد الحوفي، وبدوي طبانة، دار نهضية مصر للطبع

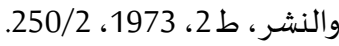

(4) المنهاج، ص 64. ومن الطرق التي تتحقق بها التمويهات كما يرى القرطاجني:

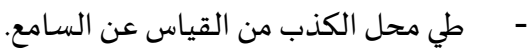

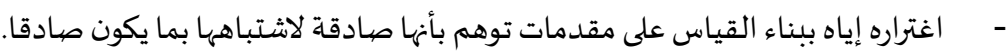

- - ترتيب القياس على وضع يوهم بأنه صحيح لاشتباهاه بالصحيح.

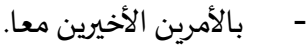

بإلهاء السـامع عن تفقد موضع الكذب بضرئروب من الإيداعات والتعجيبات التي تشغل النفس عن ملاحظة محل الكذب والخلل 


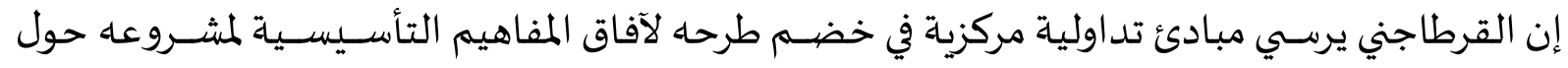

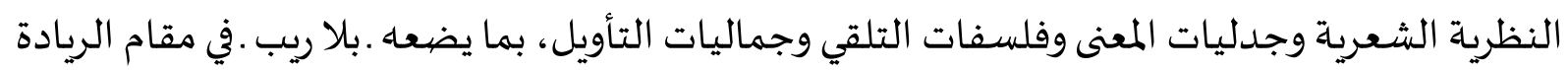

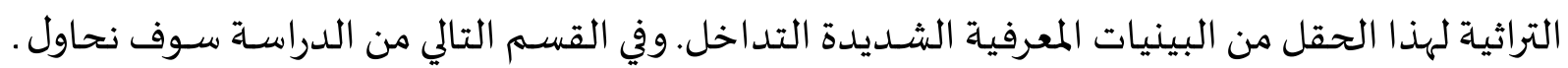

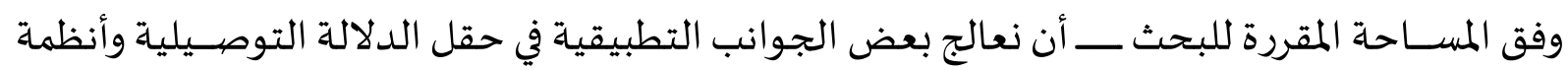

2. الأنظمة الدلالية والإشارية (عناصر التلقي وآليات التوصيل):

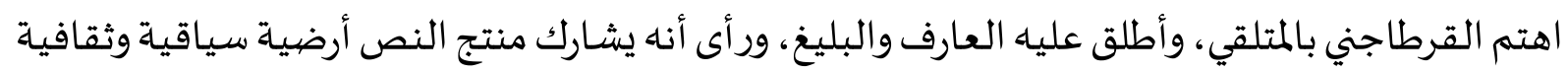

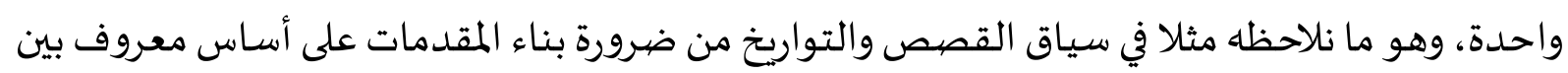

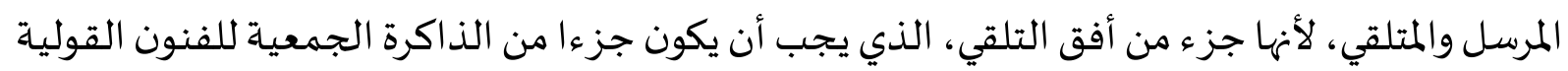

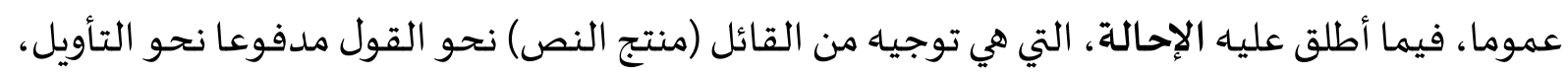

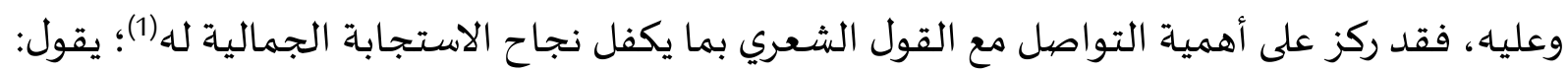

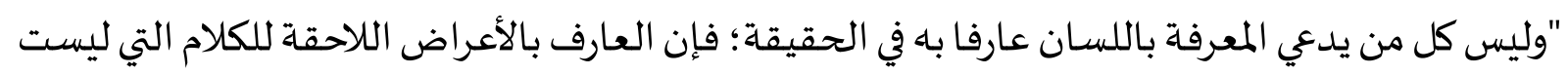

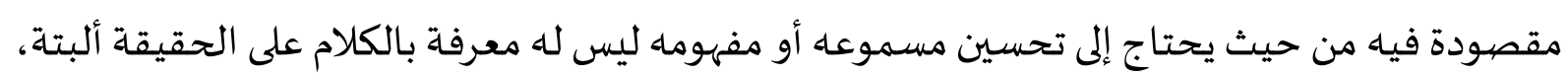

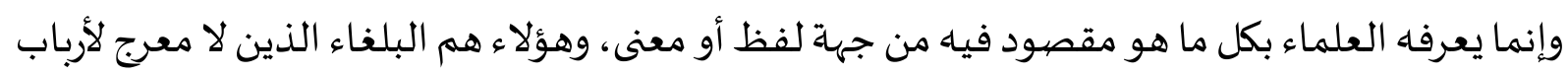
البصائر في إدراك حقائق الكلام إلا على ما أصَّلوه."(2).

1-2 الأسس التخييلية العامة للدلالات والإشـارات عند القرطاجني:

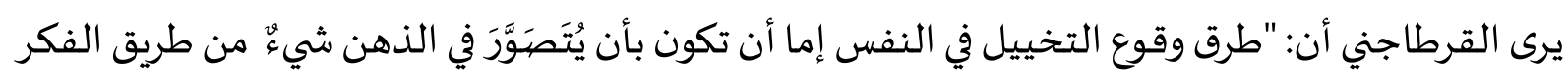

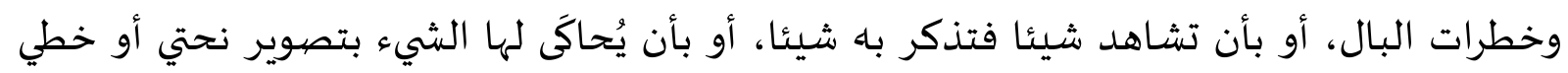

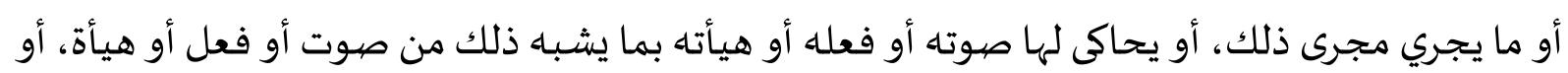

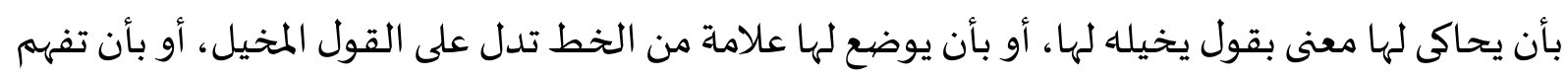

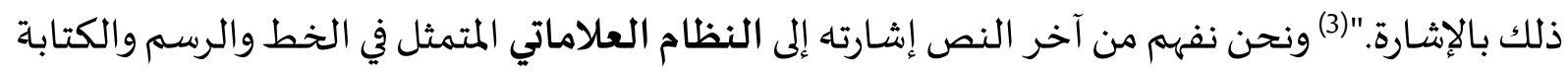

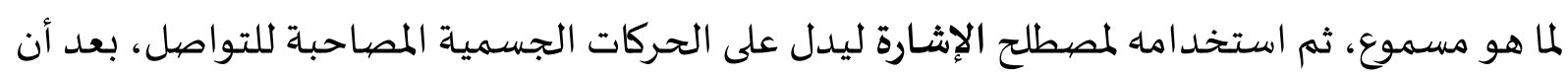

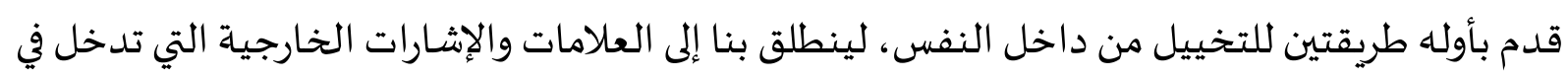

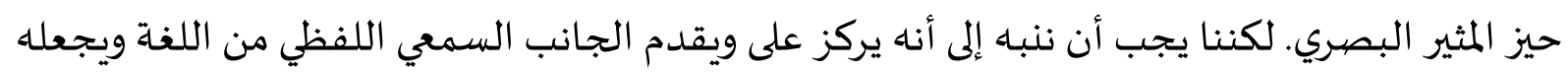

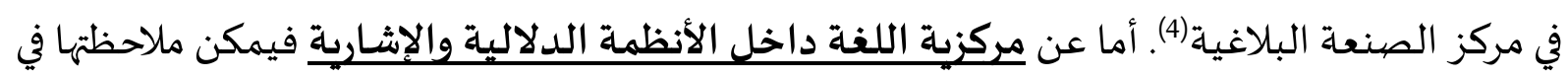

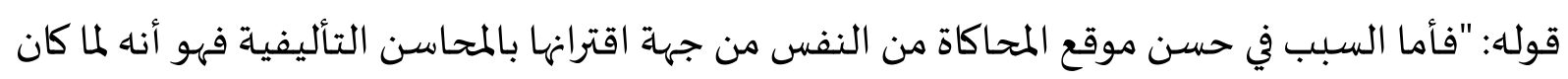

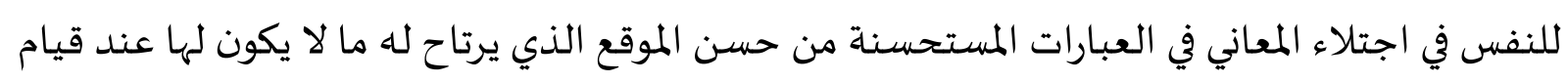

(1) (1) راجع التفاصيل في المنهاج، ص 143، وما بعدها.

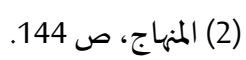

(3) المنهاج، ص ص

(4) راجع المنهاج ص 19، وانظر تفاصيل تحليلية لهذا الأمر عند فاطمة الوهيبي، نظرية المعنى، مرجع سابق، ص 44. 


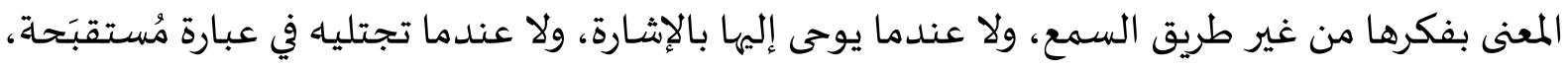

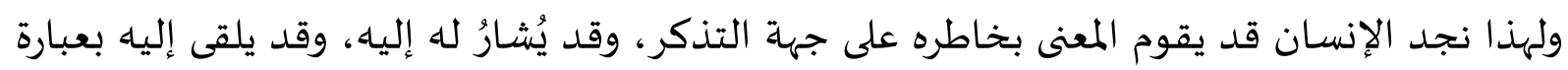

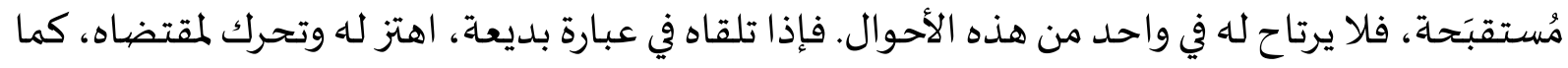

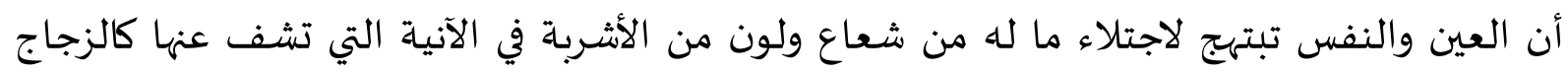

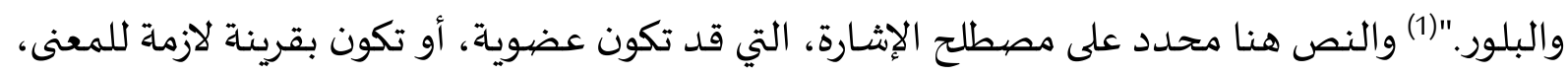

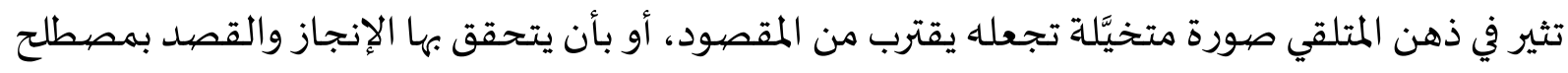

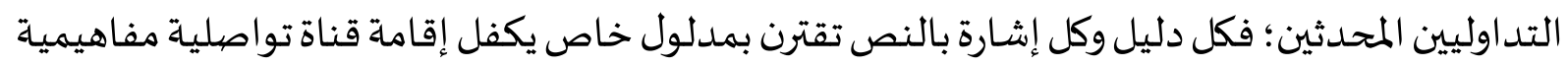
في حلقة التراسل. والنص يعكس قراءة القرطاجني العميقة للمعنى التواصلي، الذي هو قلبُ الوجود الإنساني المتحقق من خلال اللغة، وهذا المعنى قد يكون (2): قائما في الفكر دون وسيط سمعي أو شفهي. أو متحققا بالإشارة العضوية أو المرتبطة بقرينة.

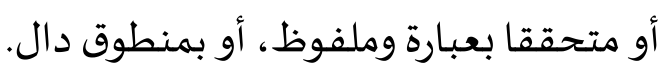

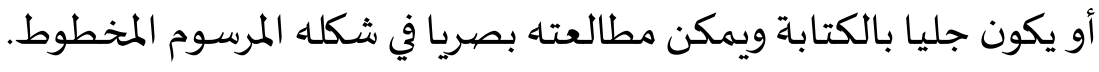

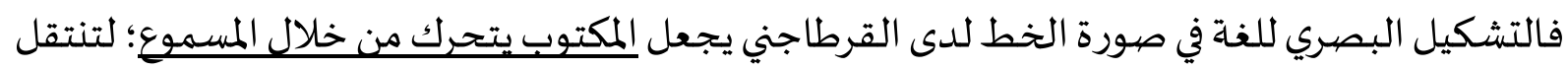

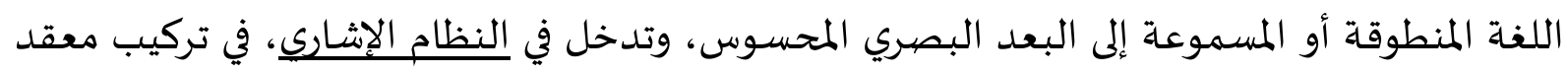

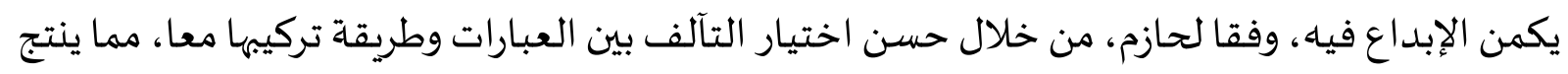

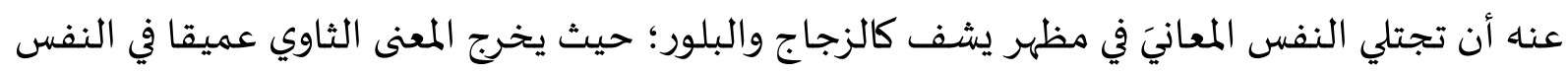

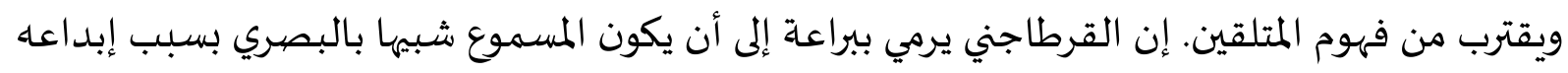

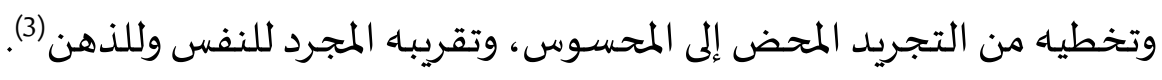

2-2 المعاني الذهنية ومجالها الدلالي والوجودي:

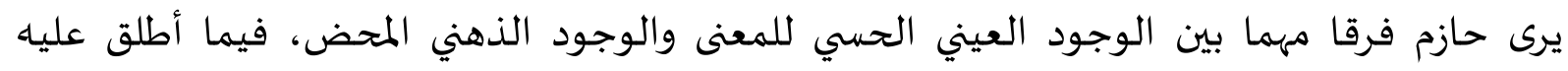

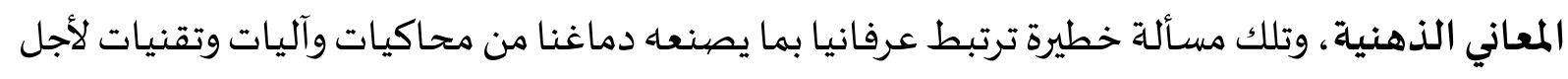

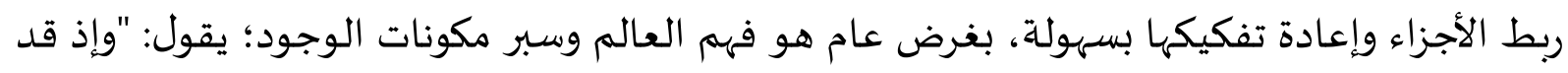

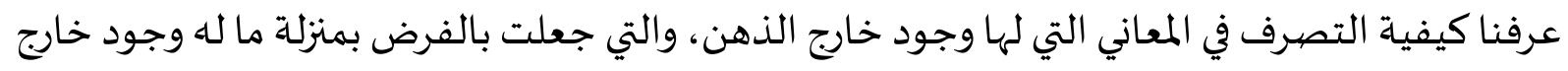

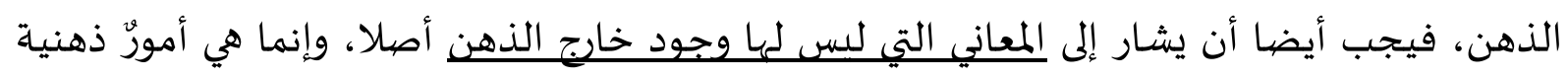

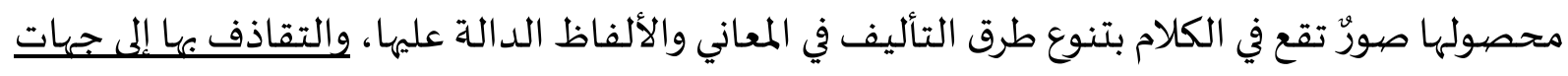
من الترتب والإسناد؛ وذلك مثل أن تنسب إلى الشيء على جهة وصفه بهاء أو الإخبار عنها أو تقديمه عليه في 
الصورة المصطلح على تسميتها فعلا أو نحو ذلك؛ فالإتباع والجر وما جرى مجراهما معان ليس لها خارج

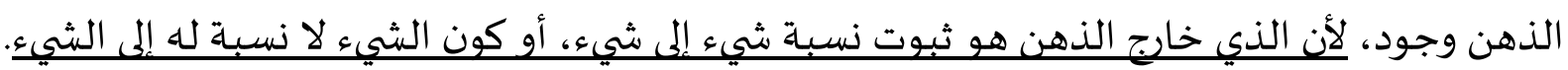

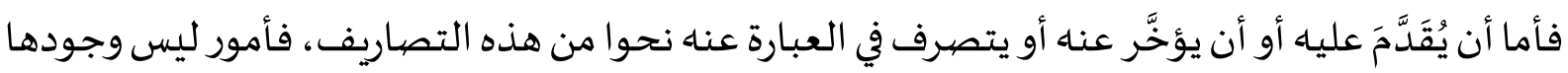

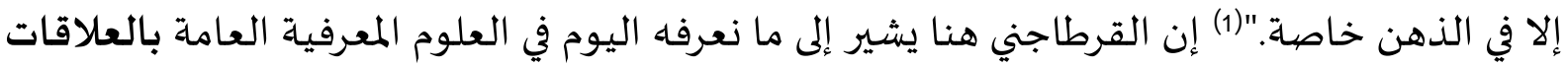

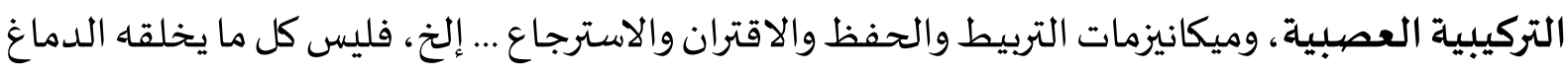

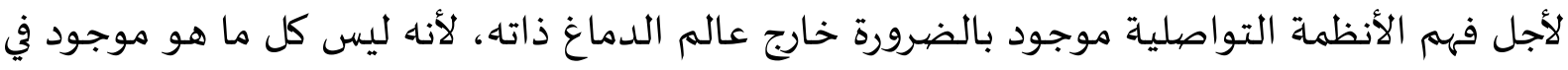

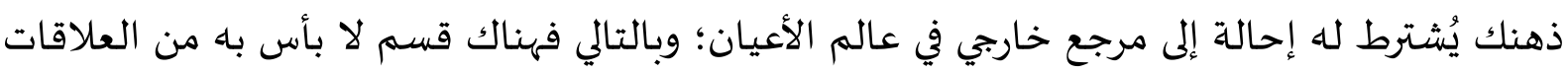

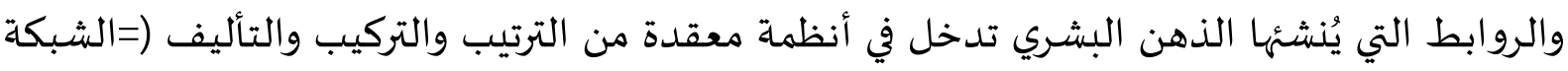

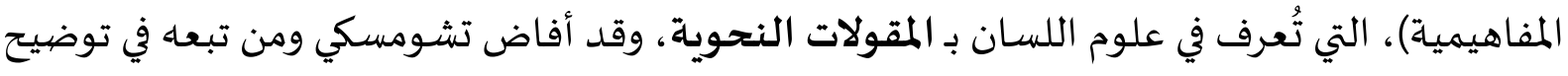

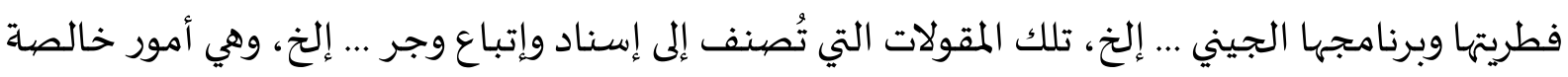

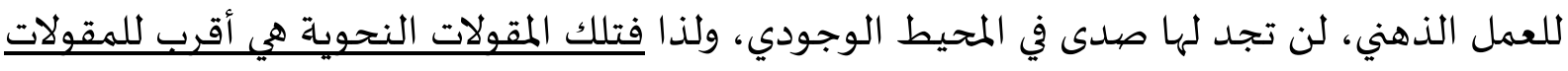

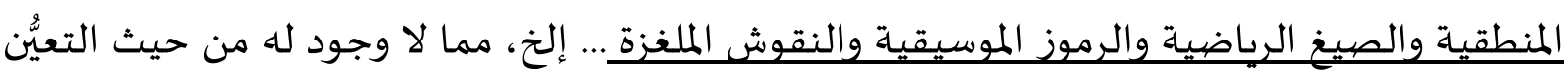

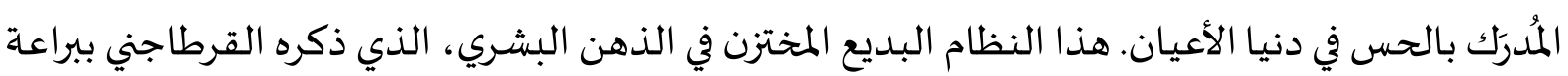

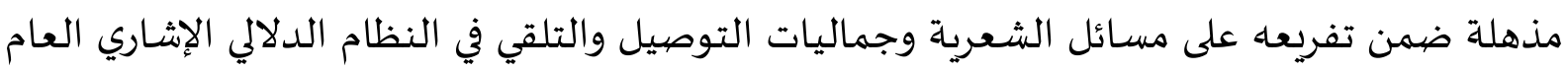

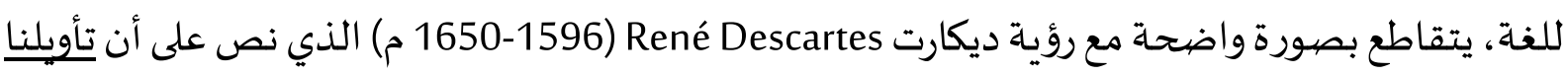

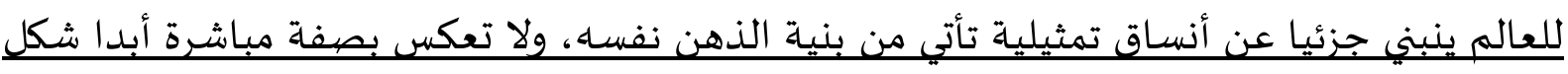

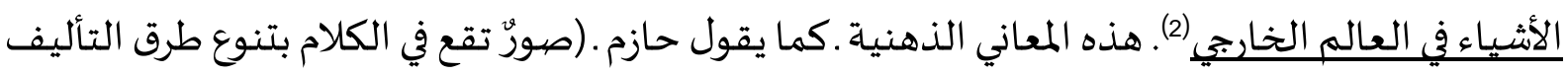

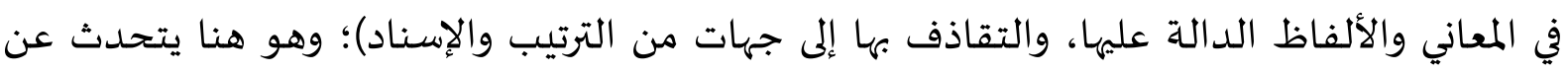

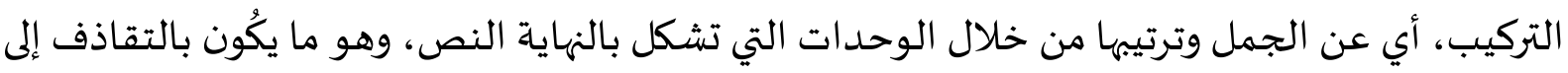

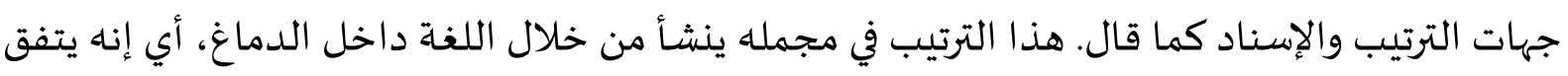

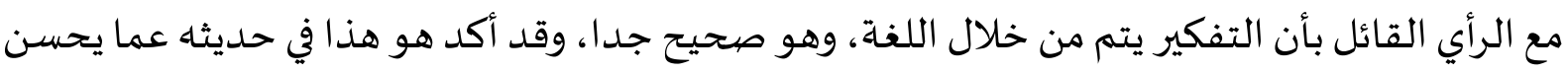

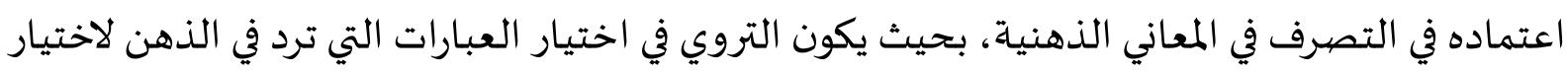

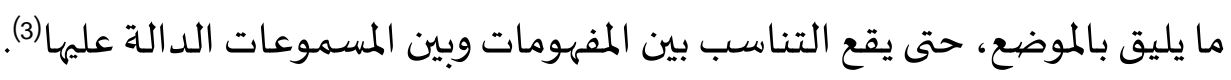

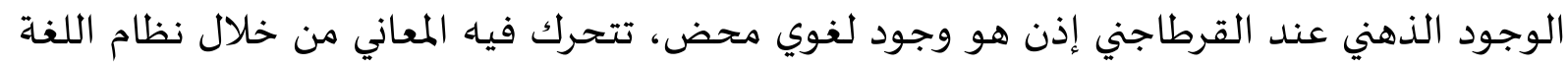

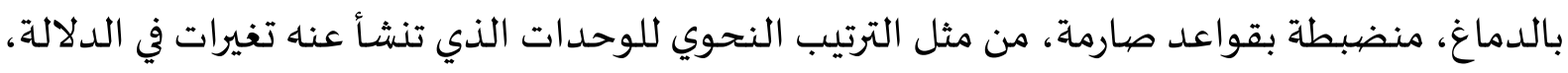

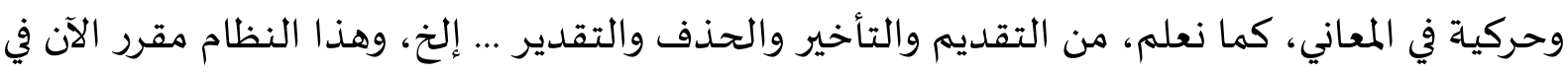

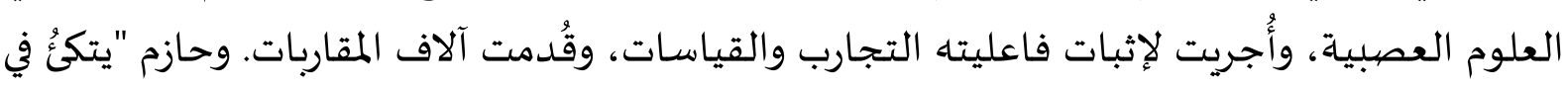

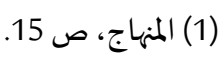

(2) زهير الخويلدي: ما لديكارت وما على الديكارتية، مقالة منشورة بموقع ملتقى ابن خلدون للفلسفة والأدب، بتاريخ 2014/12/26: http://ebn-khaldoun.com/article_details.php?article=1975

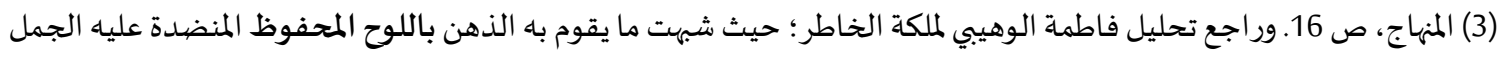

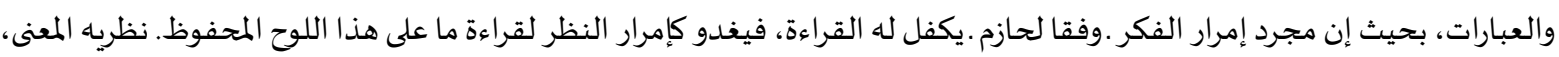


جزء كبير من مقولاته في الشعرية على المقولات النحوية، ويستثمرها لإنتاج الشعرية؛ فمثلا يعتمد على الإسناد

في تطوير العلاقة والنسبة، وكيف يمكن أن تخلق حالاٍٍ وإمكاناتٍ محتملةً مفتوحةً للقول الشعري. كما

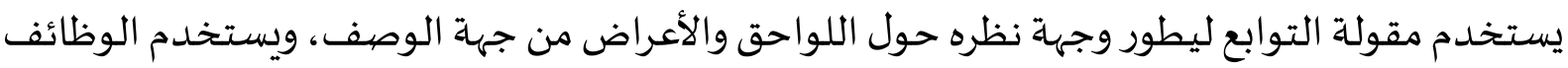

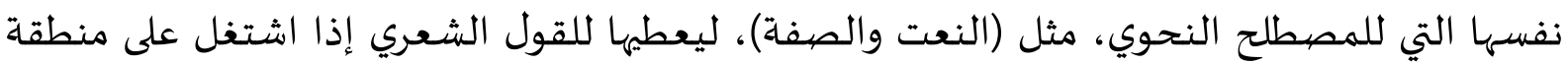

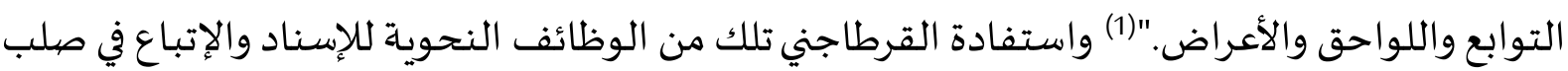

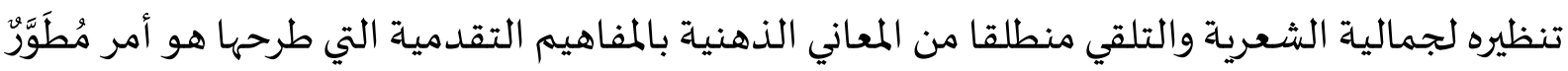

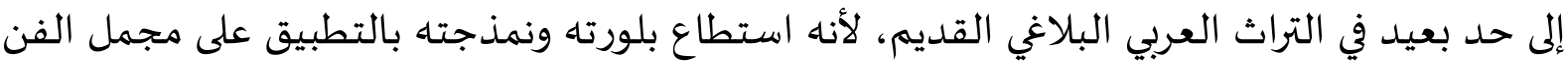

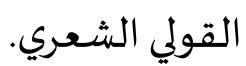

ب- إن أحوال المعاني وجوديا عند القرطاجني تدور حول محورين القدئ: - وصفُ أحوال الأشياء التي فيها القول. - ووصفُ أحوال القائلين.

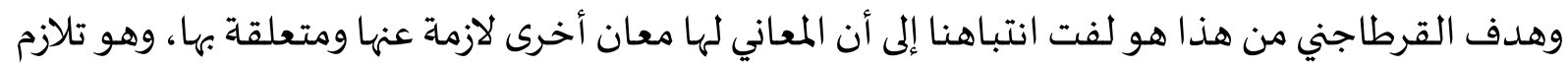

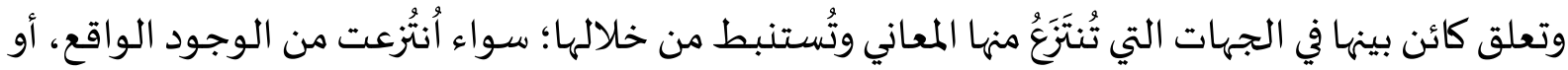

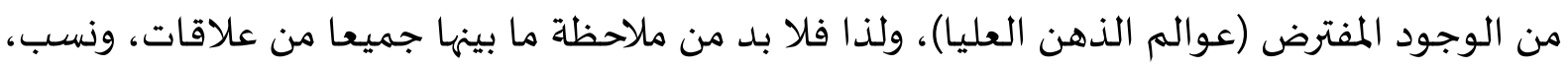

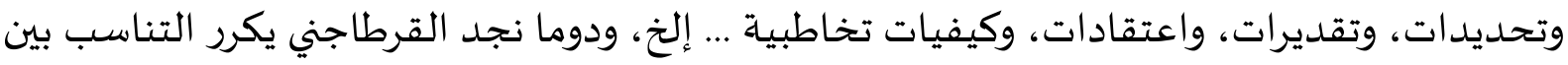

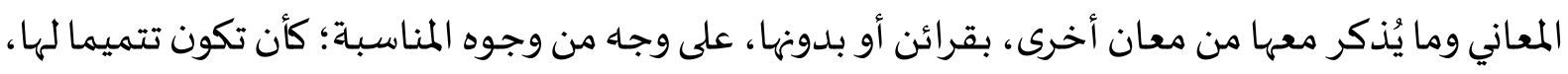

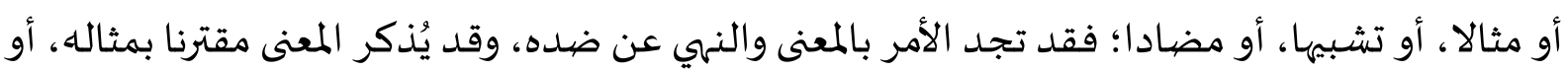

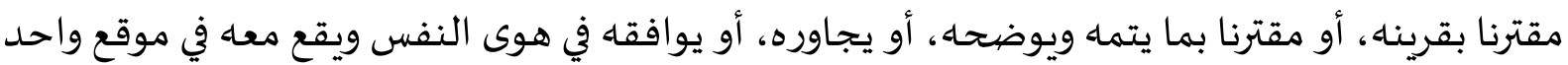

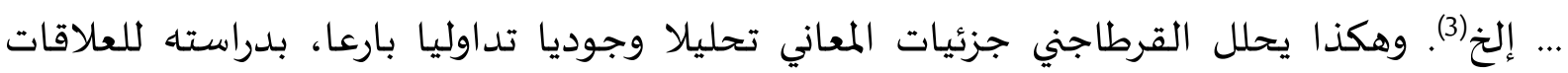

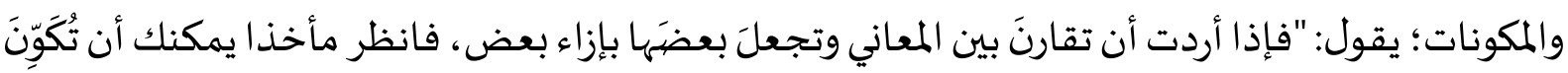

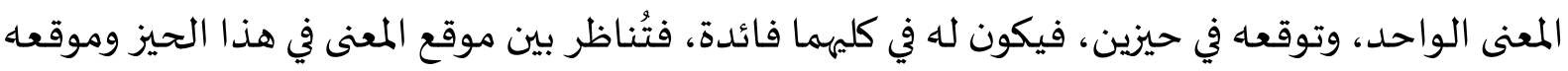

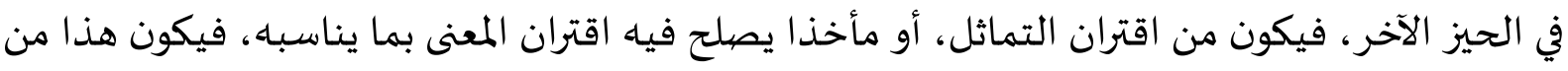

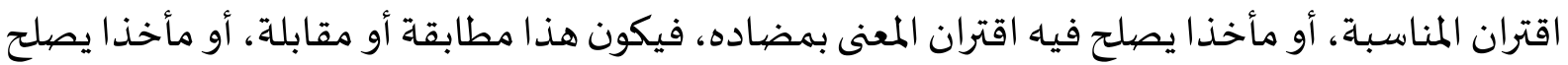

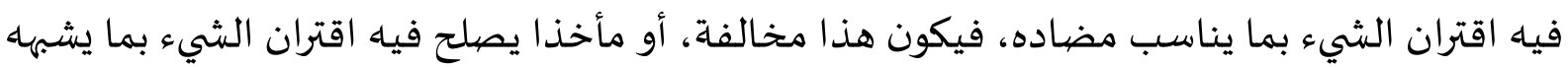

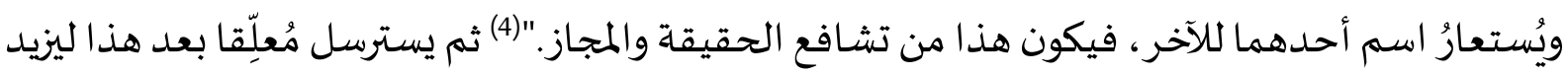

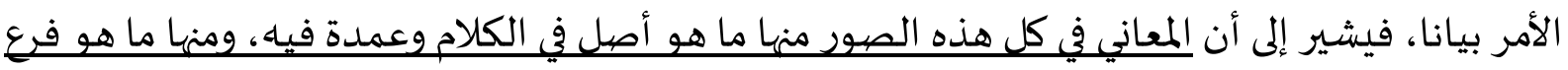

(1) فاطمة الوهيبي، نظرية المعنى، المرجع نفسـ، ص 61 (2)

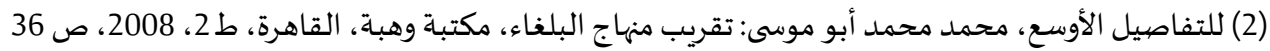


أو فضلة أو تابع لهذا الأصيل على وجه التميز أو تحقيق صحته بدليل يحقق هذه الصحة، أو أن تَسُوقَ

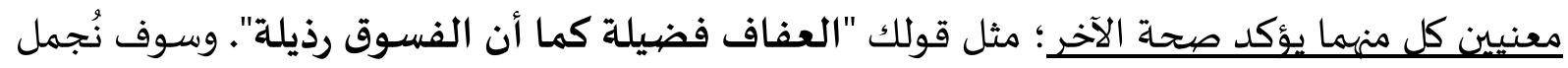
هذا كله بالتحليل بعد قليل، ضمن طرح أمثلة لبعض قوانين الأبنية التداولية للمعنى عند القرطاجني.

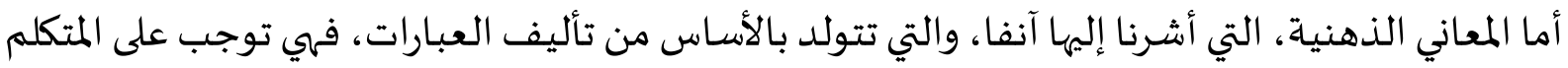

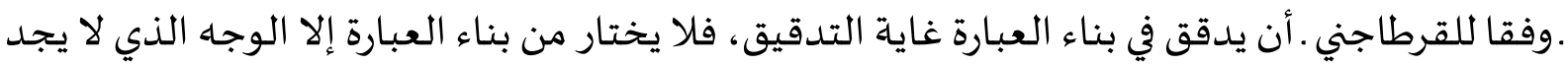
وجها أفضل منه في أداء معناها. ثم يشير إلى ضرورة تنويع بناء العبارة؛ حتى لا يأتي الكلام على وجاه من التهاء

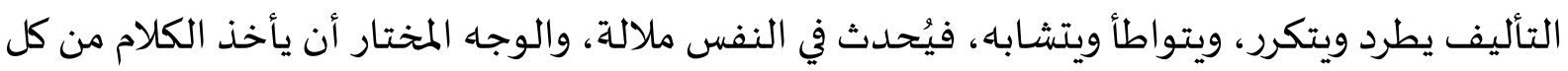

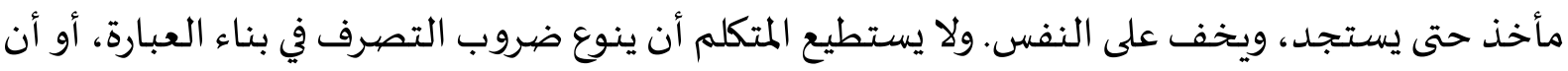

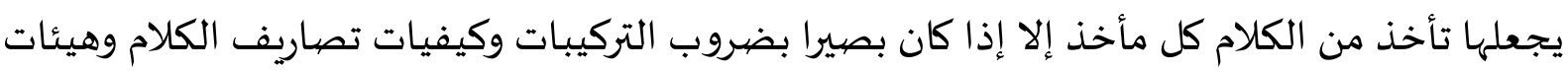

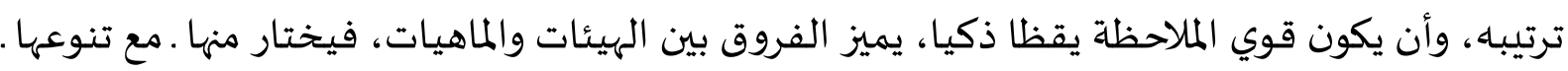

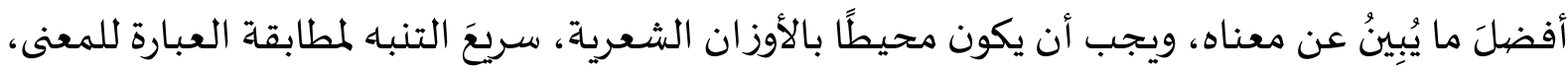

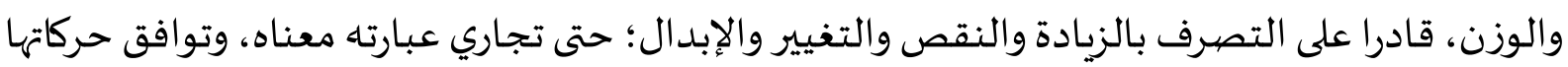

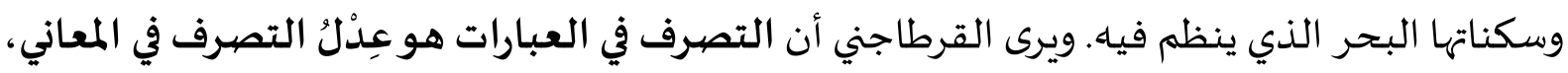

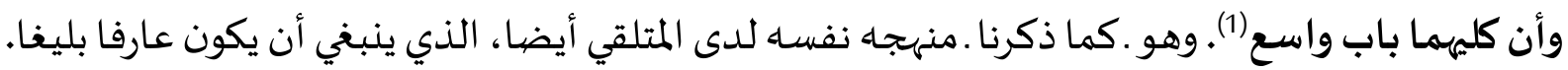

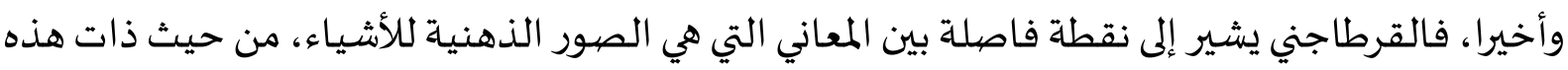

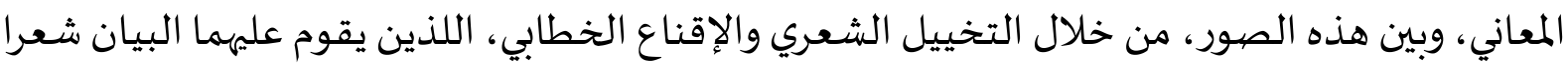

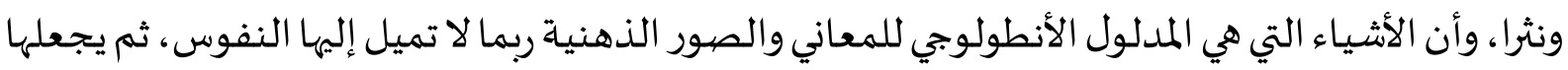

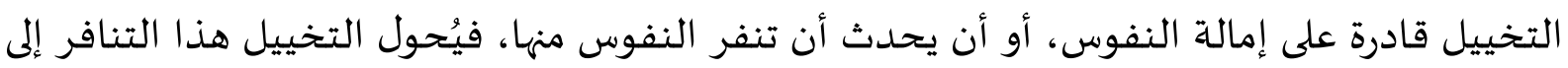

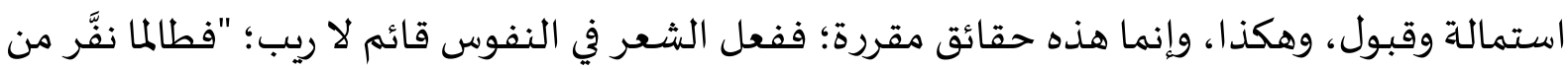

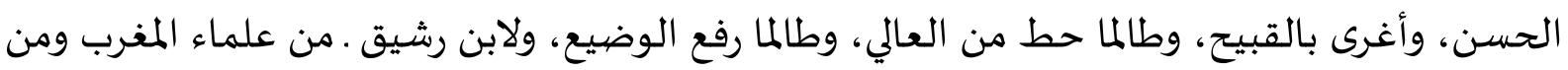

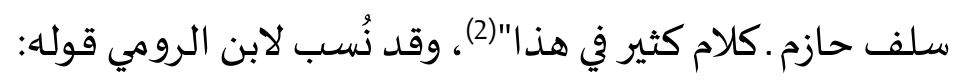

$$
\begin{aligned}
& \text { في زخرف القول ترجيحُ لقائله ** والحقُّ قد يعتريه بعضُ تغييرِ } \\
& \text { تقول هذا مجاجُ النحل تمدحه ** وإنَ تَعِبْ قلتَّ ذا قيء الزنابيرِ }
\end{aligned}
$$

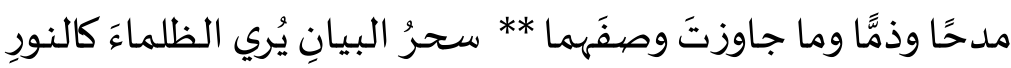

3-2 أمثلة من قوانين الأبنية التداولية للمعنى عند القرطاجني:

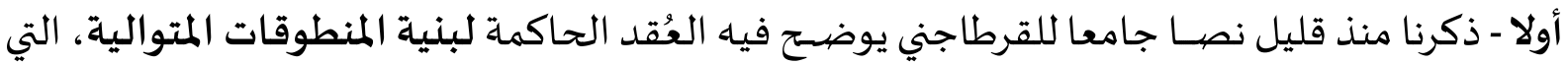

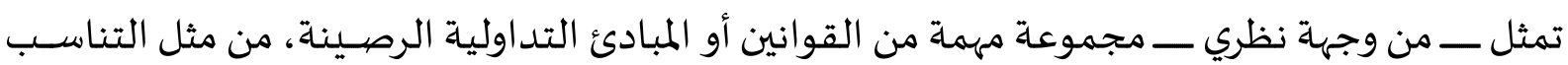


والاقتران والتلاؤم، ومفاهيم أخرى كثيرة، لا يتسـع المقام لبسـطها جميعا، لكنها تمثل بؤرًا معرفية مضـيئة في نظرية حازم الكبرى حول فنون القول، ويمكننا استخلاص ما نراه مهما في النقاط الموالية: "للأغراض أجنـاس أول، من ذلك الارتيـاح والاكتراث، وما تركب منهما؛ نحو إشــــراب الارتيـاح الاكتراث أو

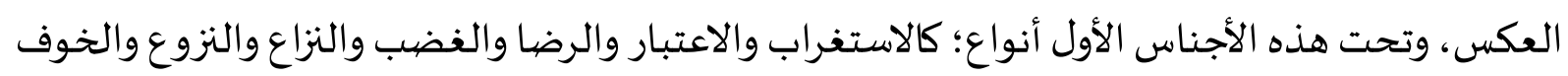

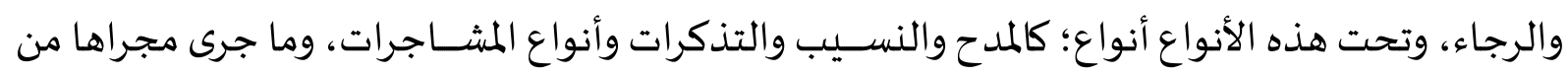

المقاصيد الشعرية." (1) (1) إن القرطاجني في هذا النص الدقيق قد سَـنَّ قوانينَ أكثر ممن ســبقوه من أوائل البلاغيين، متسـلحـا فيها

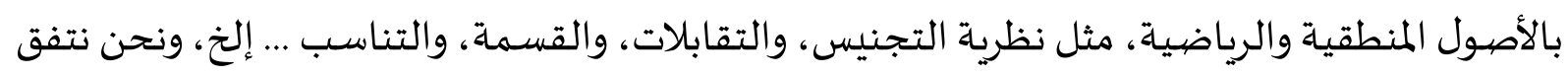

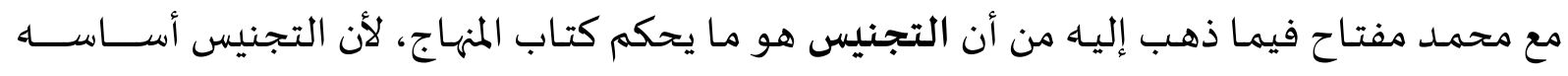

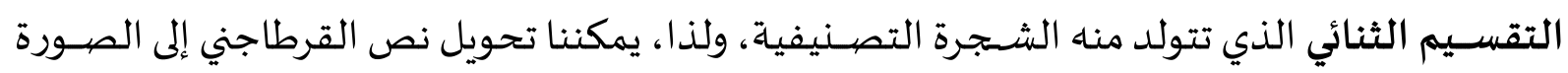

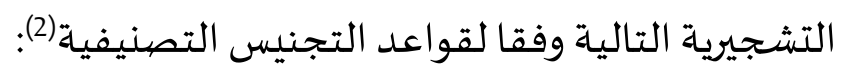

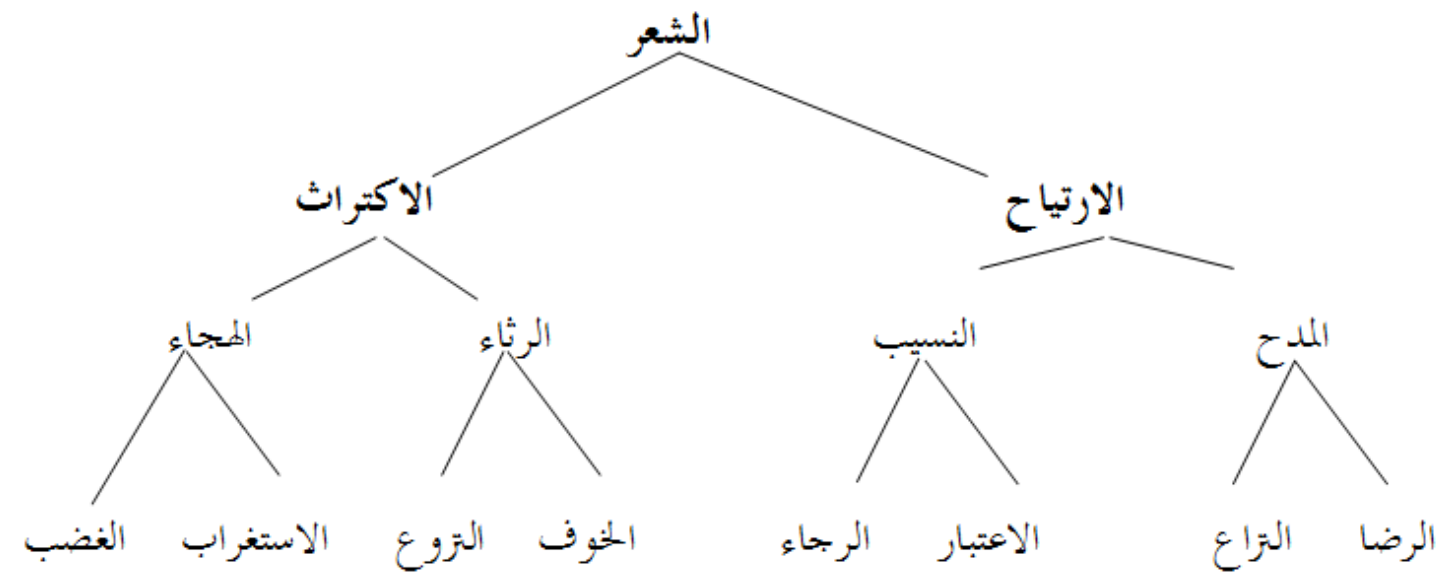

لاقتران المعاني ببعضها وجعلها بإزاء بعض أنواع خمسـة كرى: اقتران التماثل: بأن تُناظرَ بين موقع المعنى في هذا الحيز وموقعاه في الحيز الآخر.

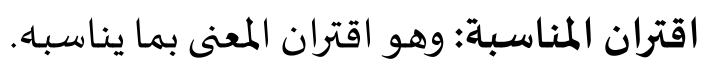
المطابقة أو المقابلة: باقتران المعنى بمضياده. المخالفة: باقتران الشيء بما يناسب مضياده.

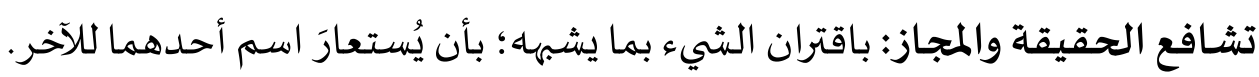




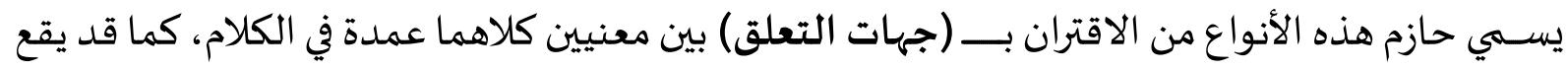

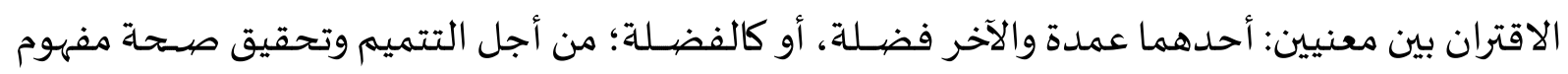

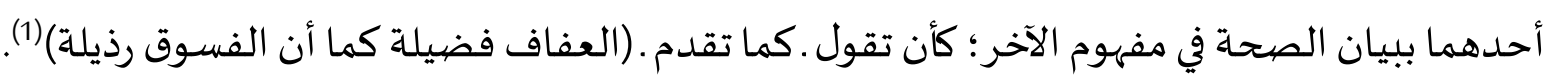

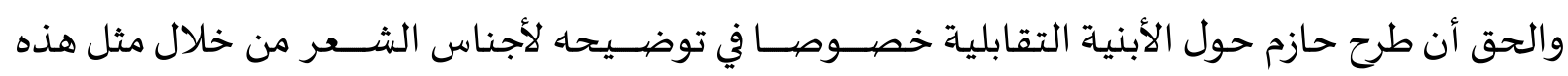

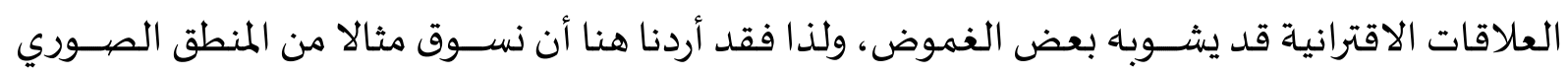

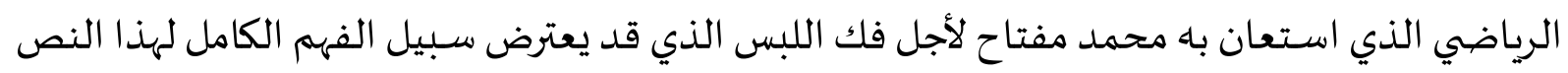

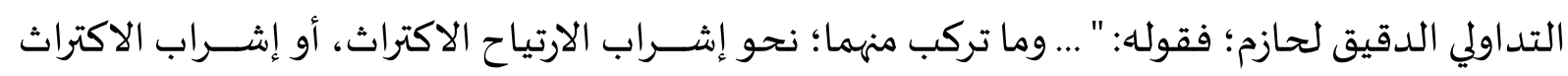

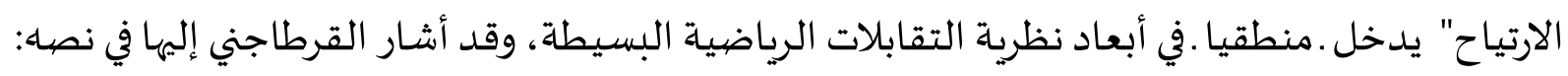

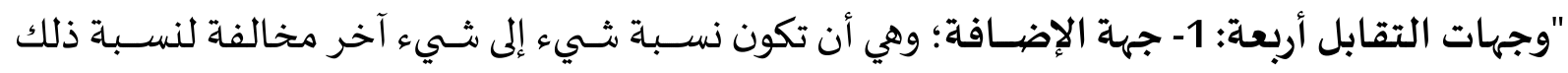

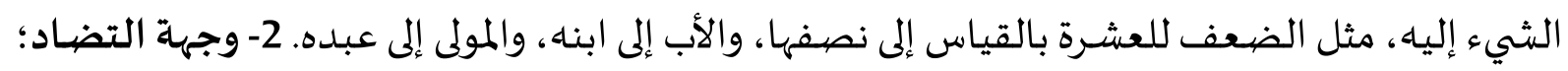

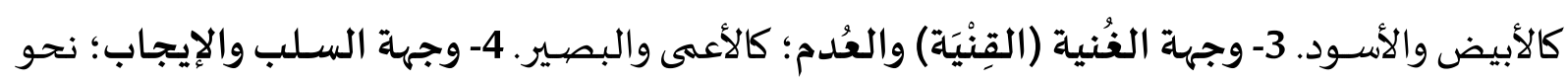

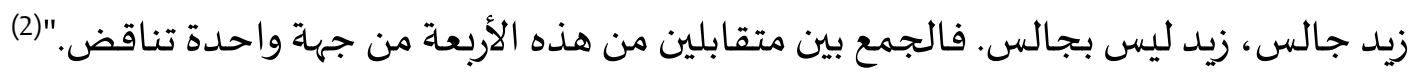
وقد ترجم مفتاح هذا الكلام بالنمذجة الصورية إلى العلاقة المنطقية الرياضية التالية (3):

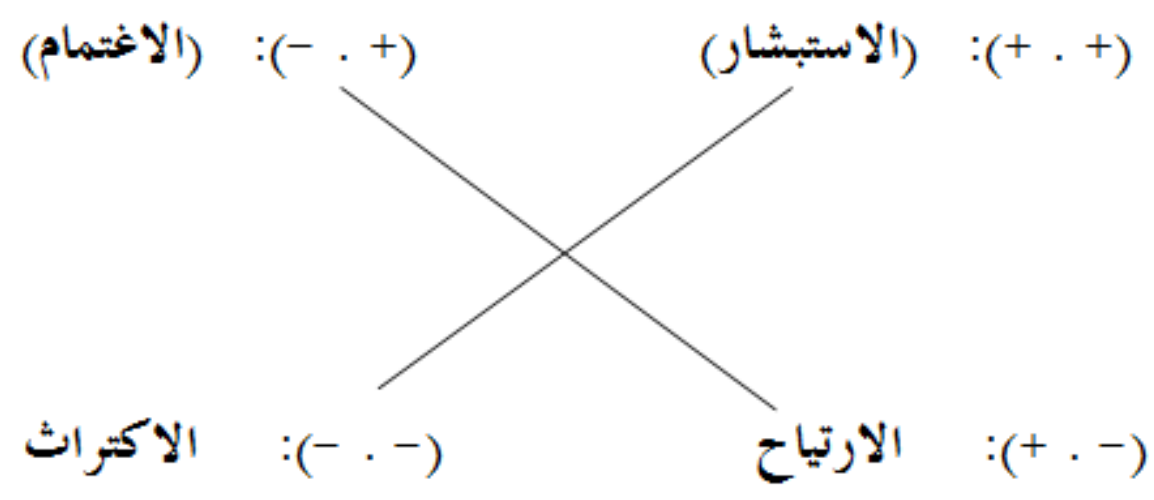

وينتج عن هذا محور العلاقة التالية: 


$$
\begin{aligned}
& \text { الاستبشار (الاغتمام والارتياح) الاكتراث } \\
& \text { (طرف) (طرف) } \\
& (-.-) \quad(+.-/-.+) \quad(+.+)
\end{aligned}
$$

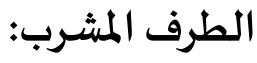

$$
\begin{aligned}
& \text { (الارتياح / الاكتراث) } \\
& (-.-1+.-)
\end{aligned}
$$

وهذا هو معنى الإثــراب؛ إذ يكون على محور شـبه التضــاد، وقد يعبر عنها أحيانا بالتردد، مثل قول

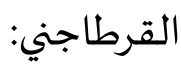
".... وكل ذلك لا تخلو أن تكون النسبة الوجوبية أو السـلبية أو المترددة بين الإيجاب والسـلب فيه أن تكون راجعاة ..."1)

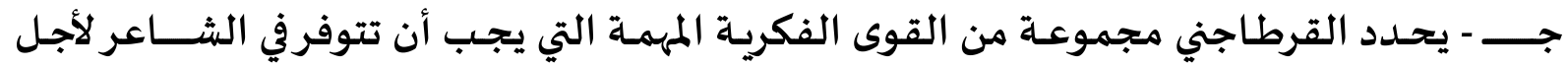

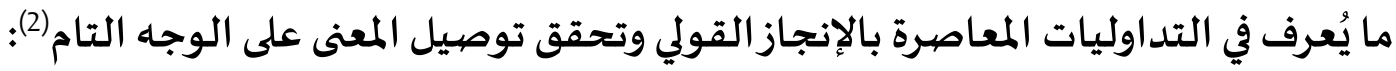

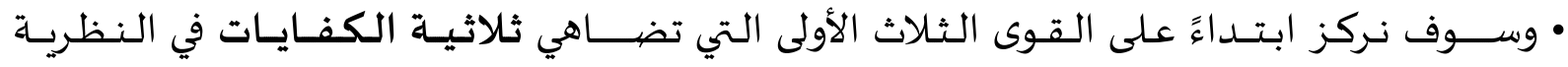

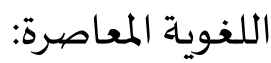
القوة الحافظة = الكفاية اللغوية (وهي المعنية بما يعرفه متكلم اللغة الأصسيلي عن لغته وما يختزنه في

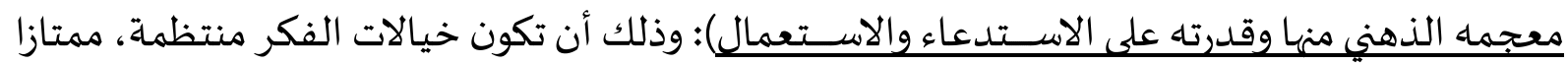

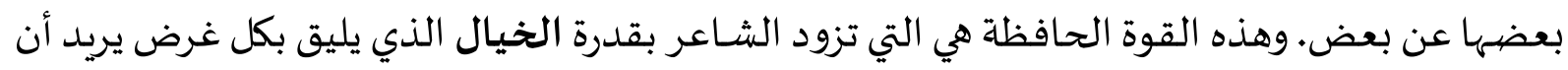
يقول فيه، من نسيب ومديح ب... إلخ. القوة المائزة = الكفاية التداولية (وهي المعنية بقدرة صـانع النص على ربط لغته بالمواقف والسـيـياقات.

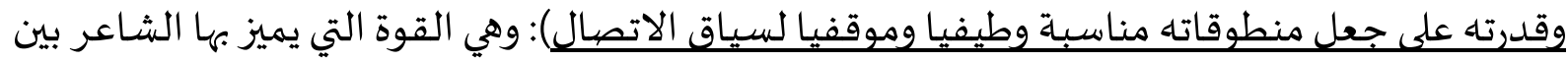

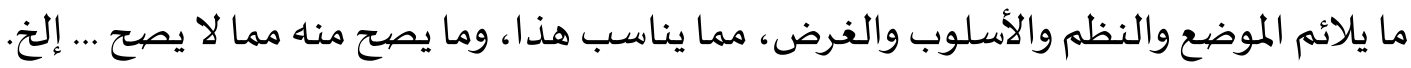

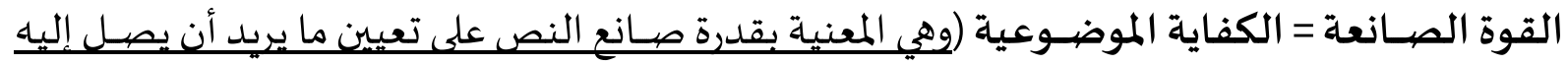

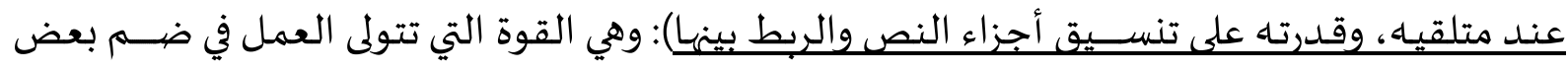


أجزاء الألفاظ والمعاني والتراكيب إلى بعض، والتدرج من بعضــها إلى بعض، وإجمالا فهي القوة التي تتولى

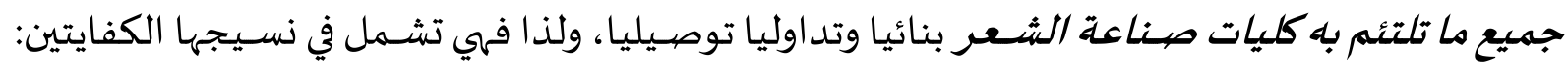

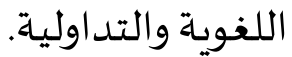

ويرى أن الشـاعر الذي يجمع بين هذه القوى الثلاث يكون متمتعا بـ (الطبع الجيد) في هذه الصناعة (1).

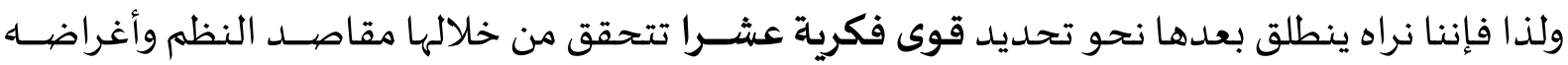

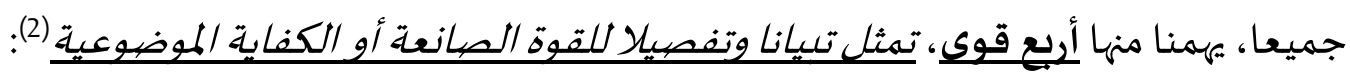

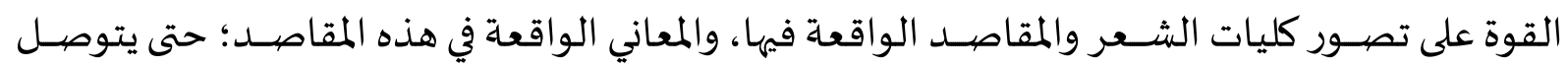

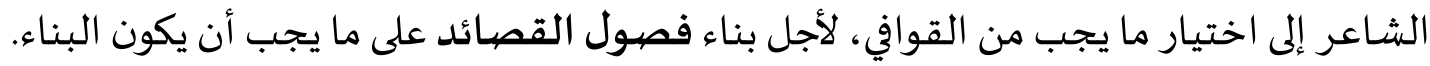

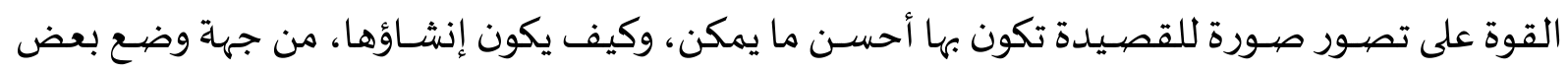

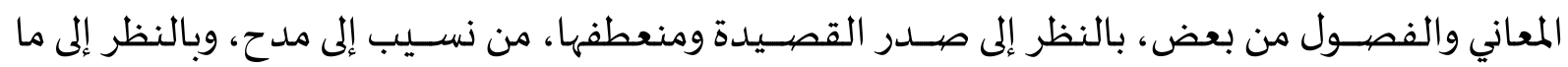
يجعل خاتمتها في حاجة إلى شيء من ذلك.

القوة على ملاحظة الوجوه التي بها يقع التناسب بين المعاني داني، وإيقاع تلك النسب بينها.

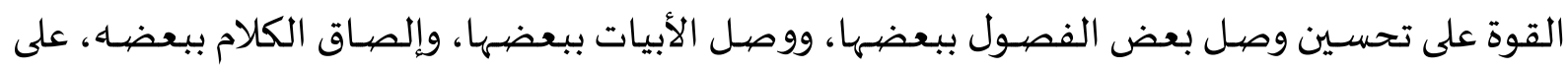
الوجوه التي لا تنبو عنها النفس.

ثانيا - الحق أن تحليل الكثير من جوانب البنية العامة للقصيدة عند الند القرطاجني بغرض بيان حبكها

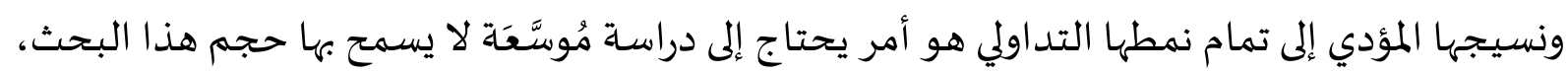

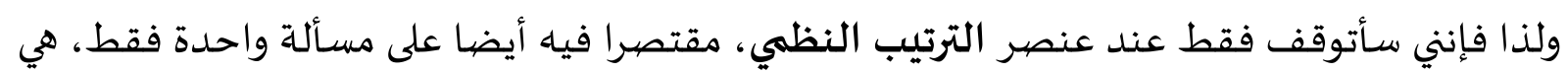

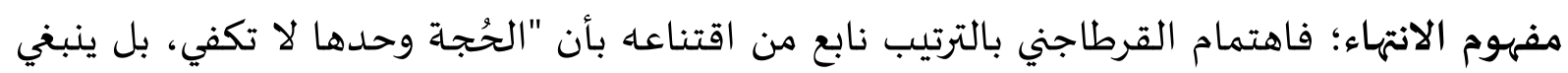

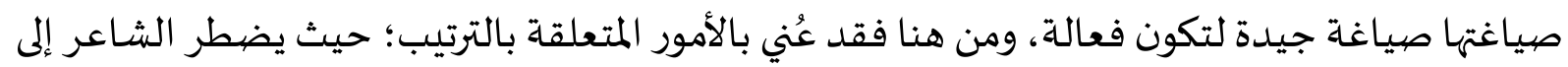

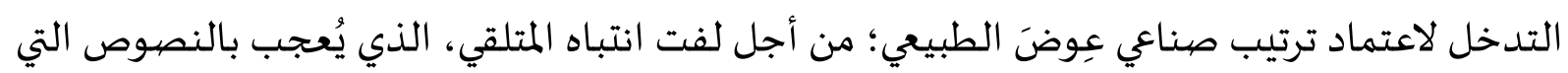

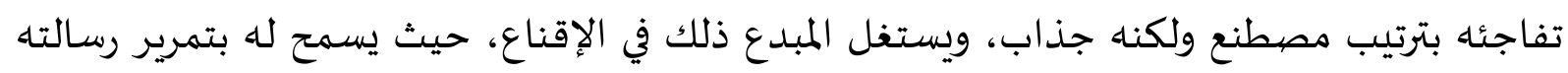

المرتبة." (3)

لقد عني حازم بالترتيب لأغراض تداولية وجمالية، فلكي يكون الكالام ناجعًا، يشترط حازم ألا يكون هناك

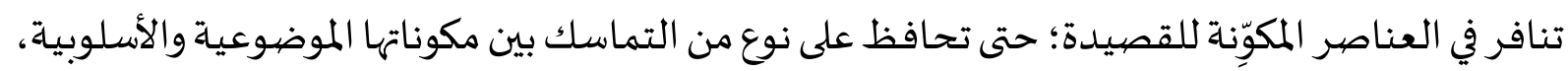

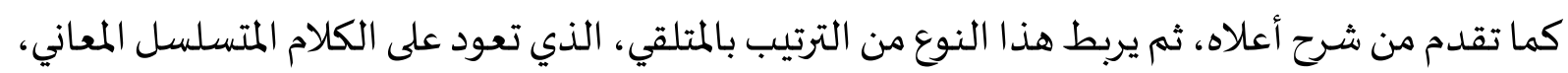

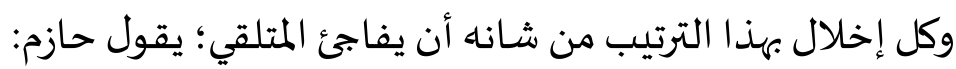

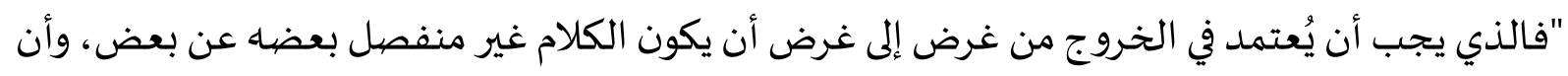

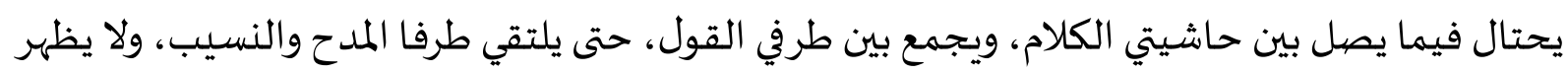

(1) (1) المنهاج، ص 43. (2) محمد العبد، النص والخطاب، ص 105. وقد أفاض العبد في تحليل أنواع الكفايات اللسانية ونقدها، في الفصل الأول من الكتاب، ص 20 وما يليها، إلى نهاية الفصل. (3) مصطفى الغرافي: الأبعاد التداولية لبلاغة حازم، منابه إلى مرجع سابق، الرابط نفساء. 
التباين في أجزاء النظام؛ فإن النفوس والمسـامع إذا كانت متدرجة من فن من الكلام إلى فن متشـاباه، ومنتقلة

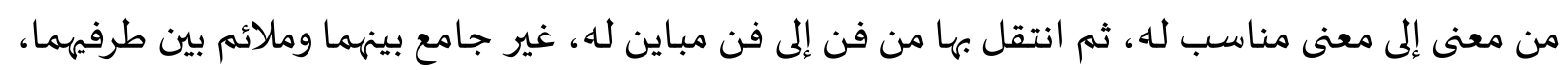

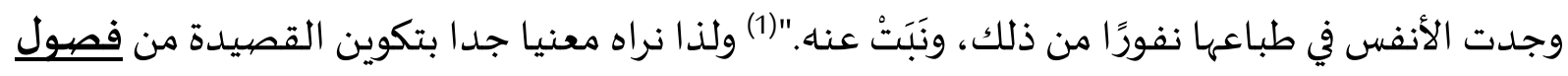
متناسقة مترابطة، حدد لكل فصل منها شروطا صارمة من الاستقصاء والترتيب وإيراد المعاني الجزئية ... إلخ؛ يقول: "فالذي يجب أن يعتمد في الخروج من غرض إلى غرض أن يكون الكلام غير منفصل بعضها من بعض ..

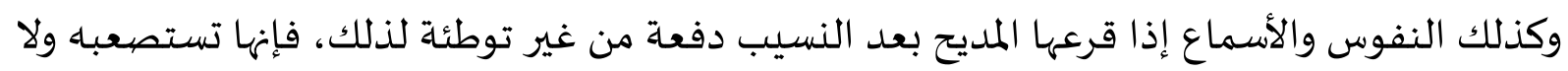

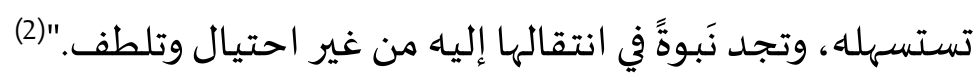

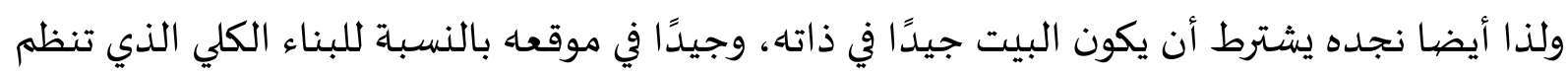
فياء القصيدة. لقد عني القرطاجني بنهاية القصيدة، وطالب الشعراء بالحرص على تجويد النهاية، لأهها آخر ما يقرع السمع، وبقدر ما تكون محكمة النسج، بقدر ما تتمكن من إطالة مدة التأثث. وهناك نوع من الانتهاء سماه حازم "التحجيل"، وذلك عندما يذيل الشـاعر أواخر فصول القصيدة بأبيات حكمية و استدلالية، وإذا تحقق ذلك "زادت الفصول بذلك بهاءً وحسنًا، ووقعت من النفوس أحسن موقع."(3) وبالرغم من أنها يجعل التحجيل نهاية الفصيول لا القصيدة، فإنها يقرر في موضع آخر أن الاختتام "ينبغي أن يكون مناسبًا للغرض؛ فيكون بمعان سارة في التهاني والمدح، وبمعان مؤسية في التعازي والرثاء."(4) "لقد عني القرطاجني بالترتيب بوصفه تابعًا للوظيفة الإقناعية ومقومًا من مقوماتها، وعيًا مناه بأن مادة

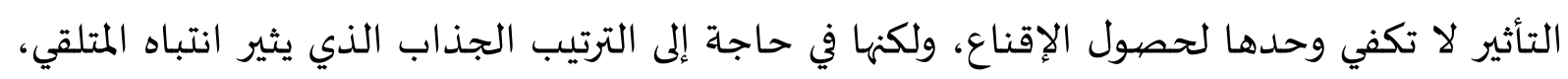

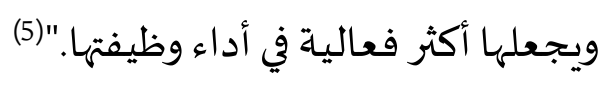

• إن قانون الخاتمة التداولي عند القرطاجني يتلخص في أنه: (ينبغي أن ترتبط الخاتمة بما قصهد إليه المتكلم في النص، وألا يكون تأثيرها فيما قبلها من حيث المعنى تأثيرا سلبيا)(6). وسوف أختتم هذا القسم (الأنظمة الدلالية والإشارية) بعرض موجز لنموذج تحليلي لتقارب المعاني

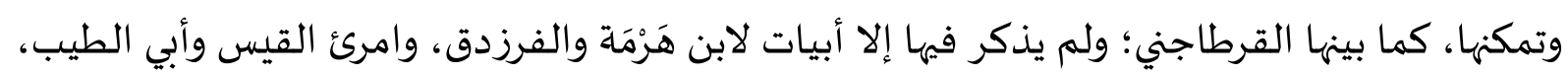

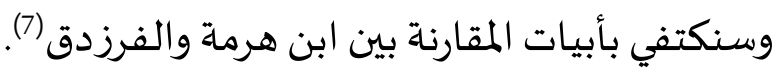

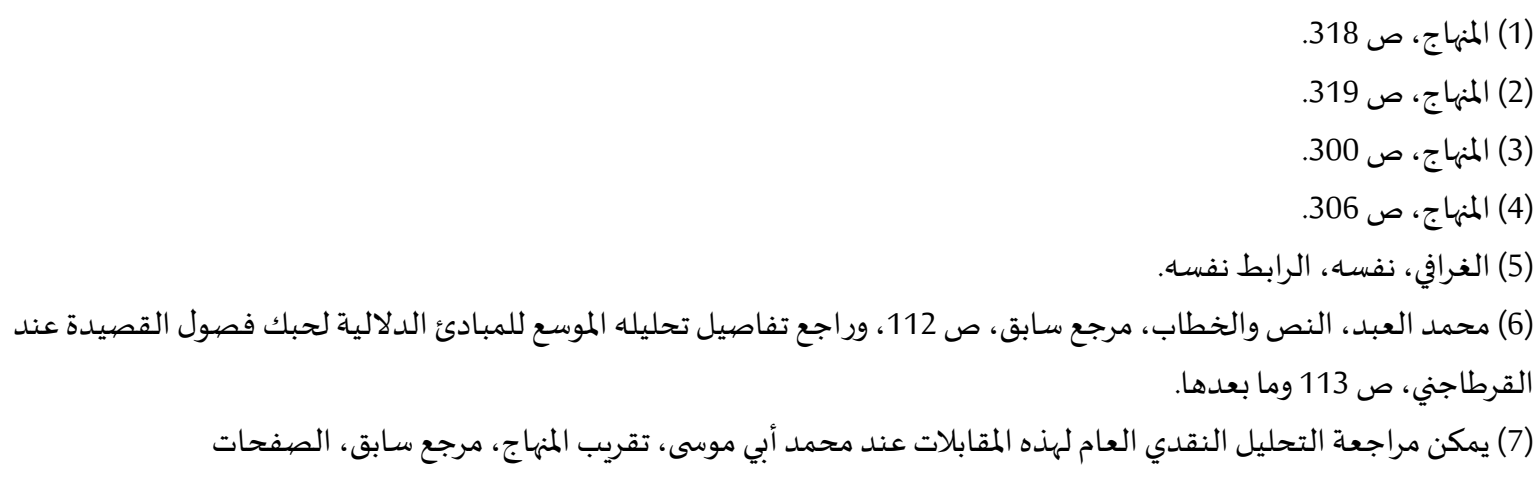




\section{4-2 - نموذج تحليلي لتقارب المعاني وتمكنها عند القرطاجني:}

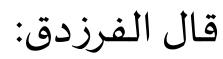

وإنك إذ تهجو تميما وترتشي ** سرابيل قيس أو سحوق العمائم

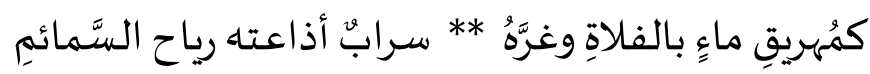

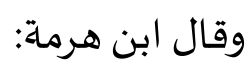

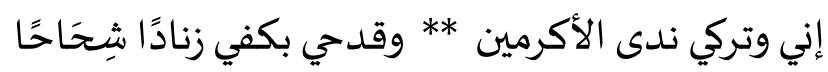

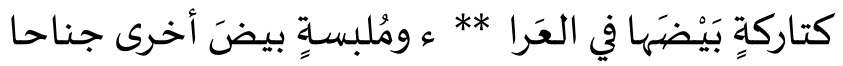

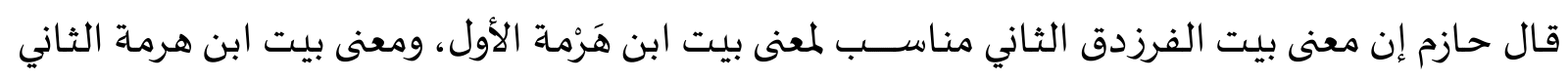

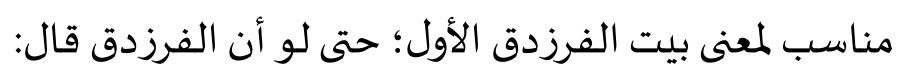

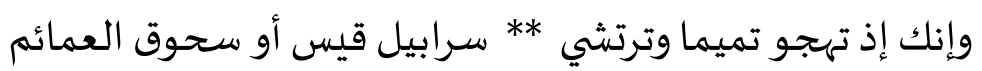

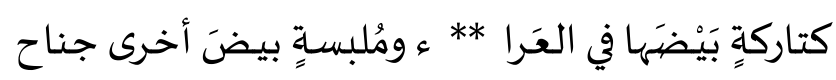

لكان قد وضع الكلام موضعاه الذي يليق به، وكان المعنى صحيحا متمكنا.

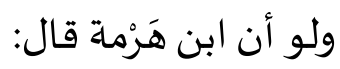

إني وتركي ندى الأكرمين ** وقدمي بكفي زنادًا شِحَاحًا

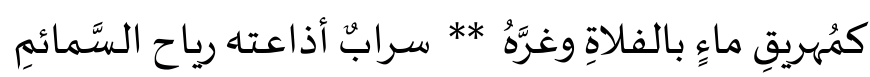

لكان الكلام صحيحا وتشبيها واقعا موقعه اللائق بهاء (1).

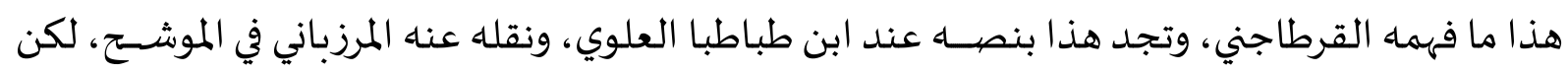

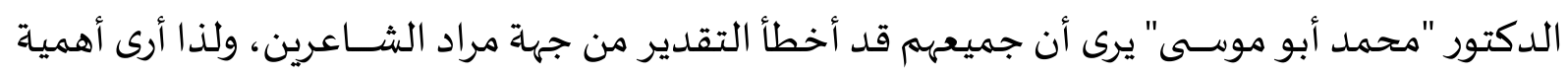

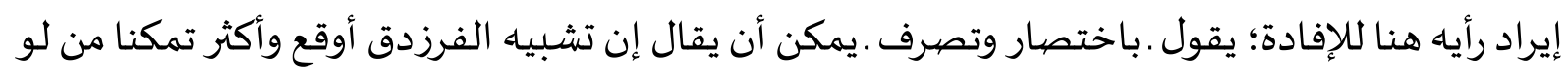

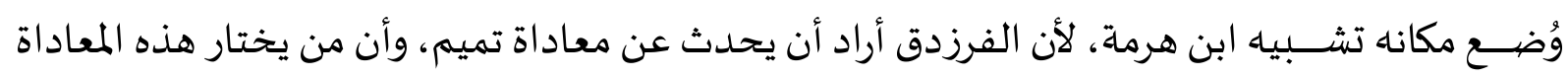

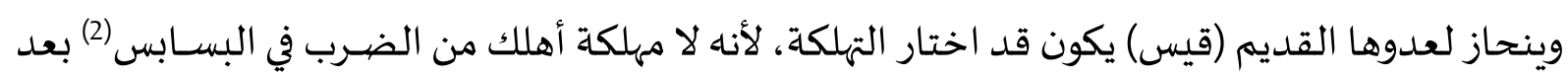

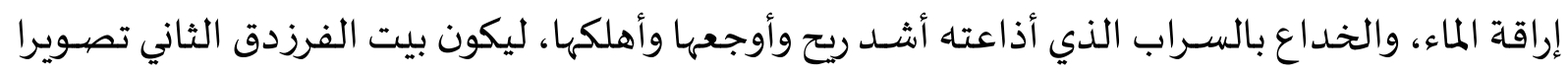

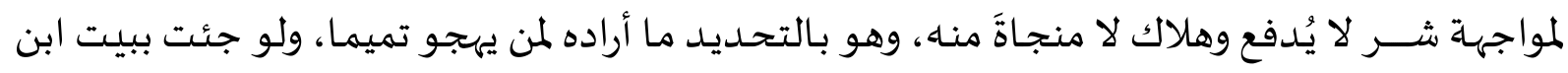

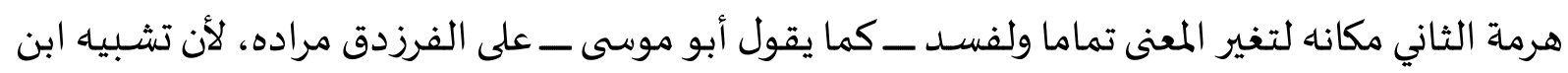

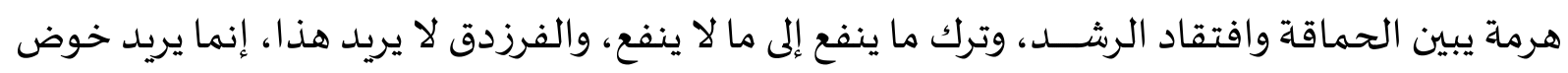

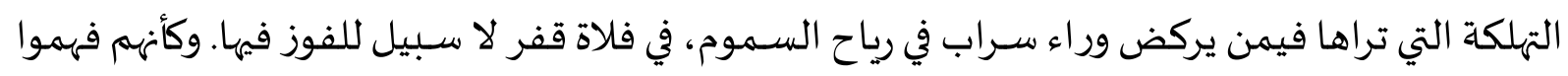

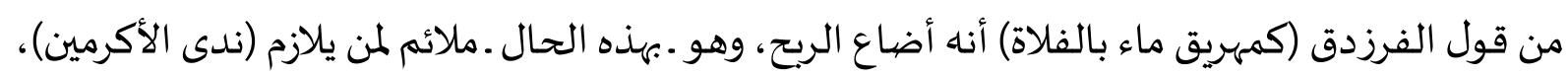

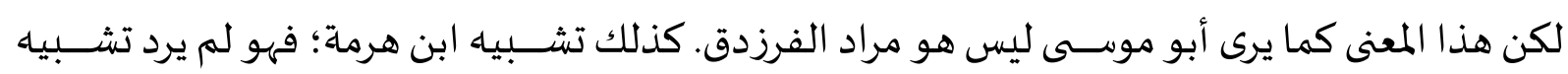

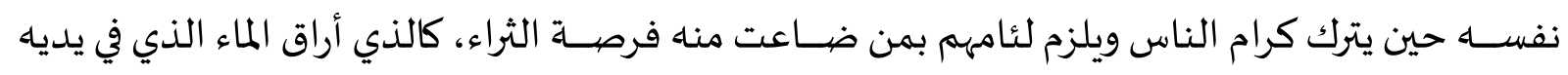




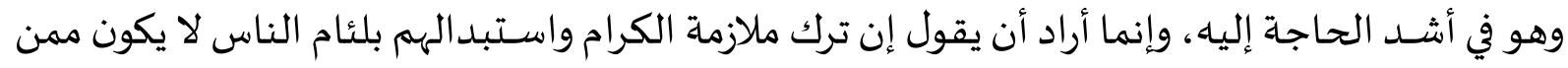

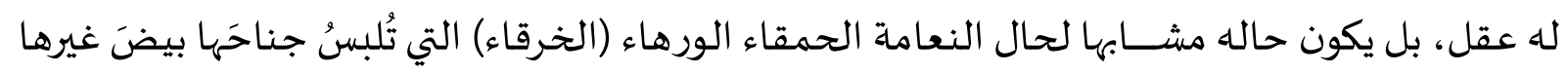

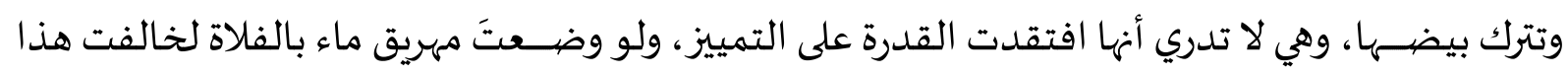
المراد ولنقضت معناه(1).

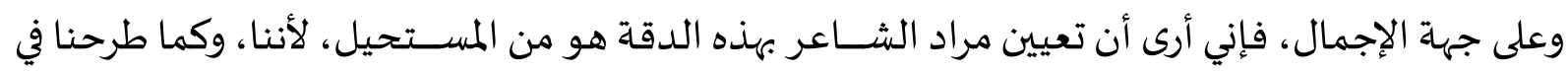

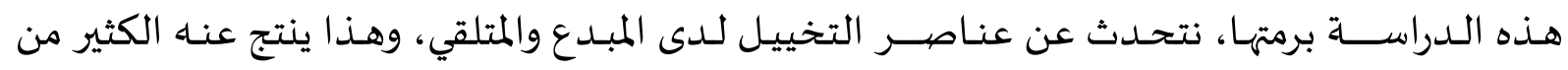

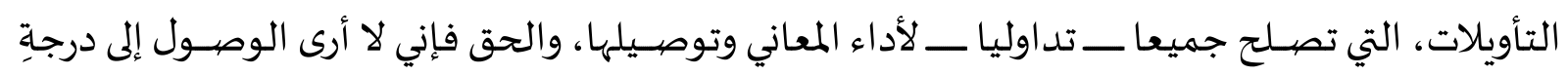

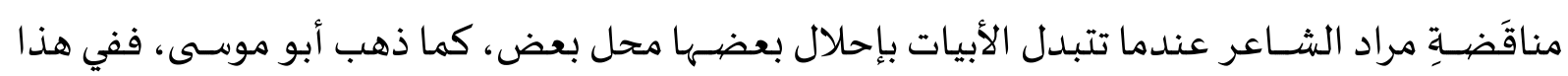

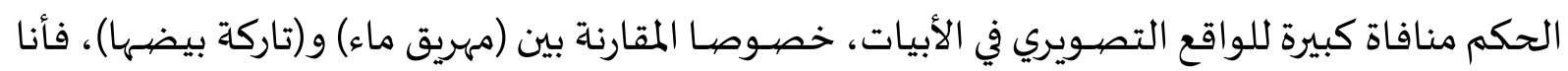

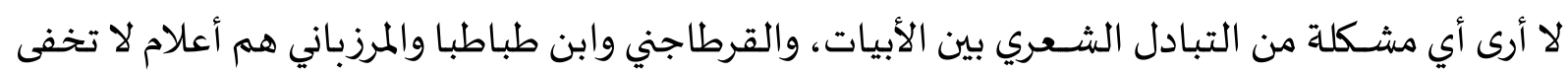

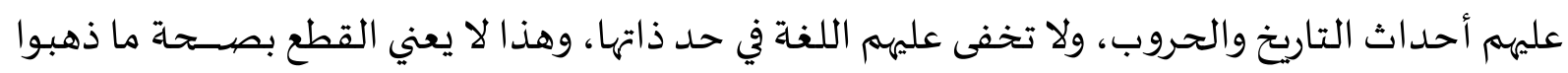

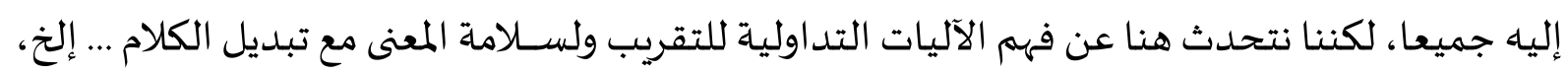
مما يدخل في عنصر التخييل المهيمن على جوهر العملية الشعرية كلها.

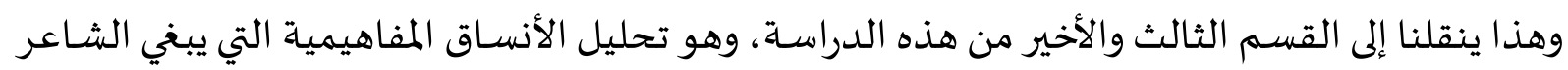

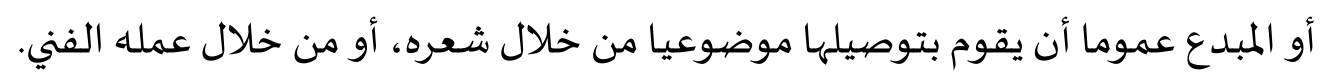


3. جدلية الأنساق المفاهيمية وتوصيل المعنى بين أُفُقَي المحاكاة والتخييل: 1-1-3 إن عملية صياغة المعطيات ضمن الأنساق المفاهيمية العامة لدى القرطاجني ترتبط بكيفية إدراك الكاك

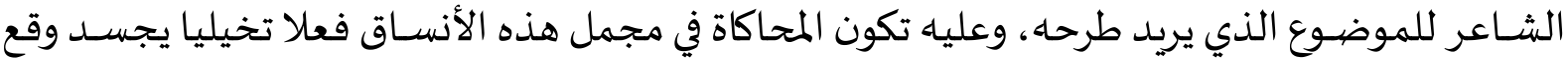

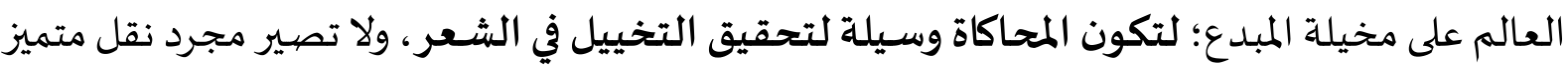

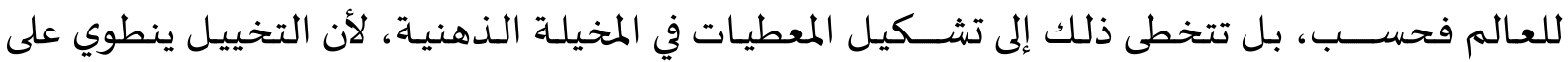

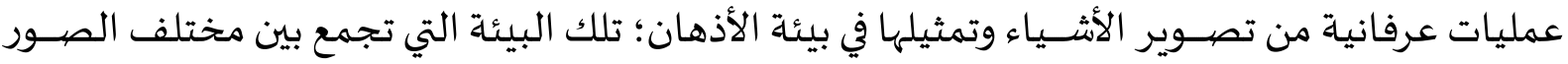

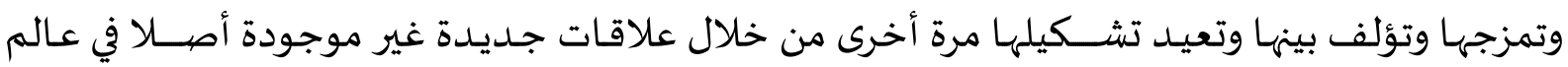

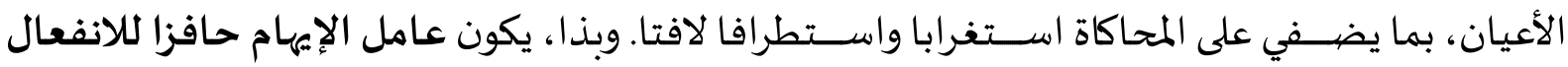
بجمالية التلقي، ومن هنا لا يمكن الفصل أبدا بين التخييل والمحاكاة في الفن الشعري الأصيل (1).

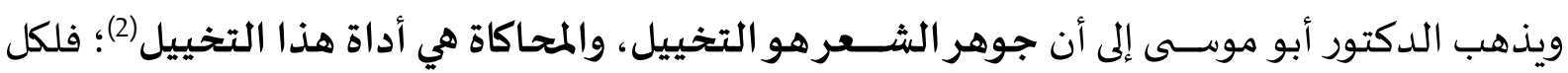

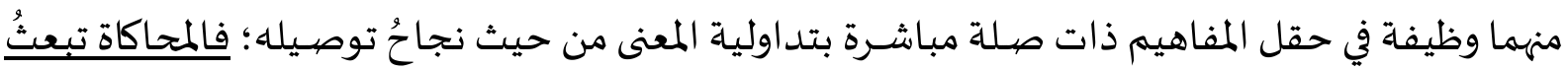

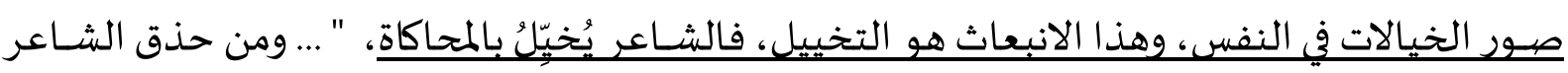
اقتداره على ترويج الكذب، وتمويهاه على النفس، وإعجالها على التأثر له قبل إعمالها الروية فيما هو عليه،

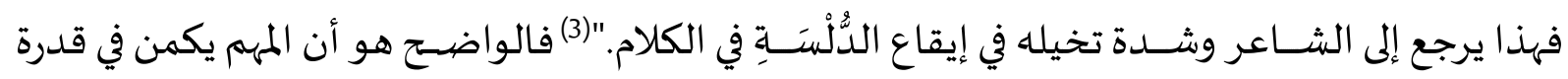

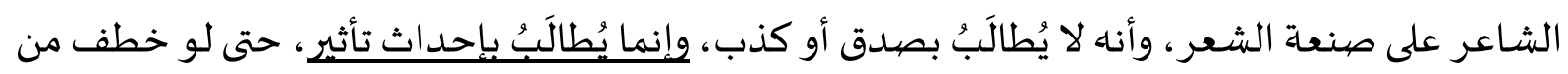

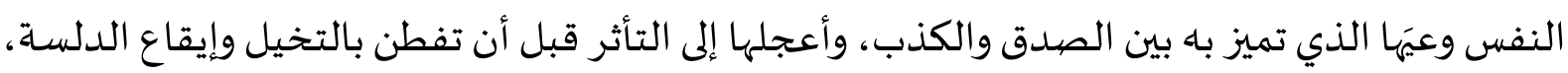

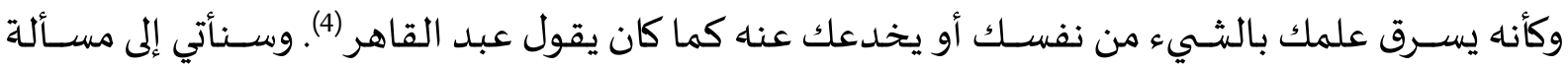
الإيهام من الجانب النفسي بعد قليل. والقرطاجني يجعل التخييل والتمثيل والتصـيـير شـيئا واحدا؛ فســواء كان الكلام قادرا على إثارة الهــور

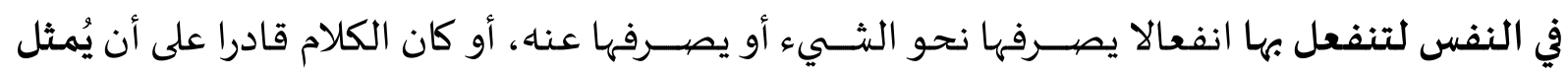

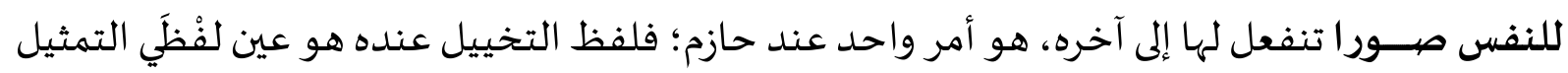
والتصوير (5). وقد فرق القرطاجني بين ما سماه التخاييل الأُوَل والتخاييل الثواني؛ يقول: " وينقسم التخييل بالنظر إلى إلى

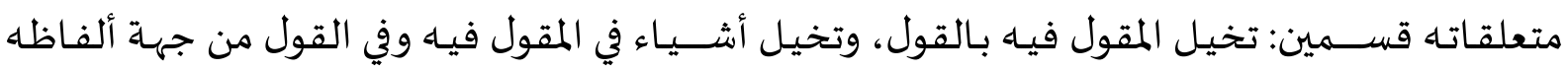

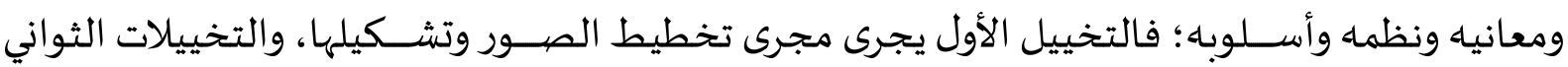

(1) راجع للتفاصيل، حبيب الله علي إبراهيم: نظرية المحاكاة عند حازم القرطاجني، مجلة الأثر، العدد 13، 13، مارس 2012،

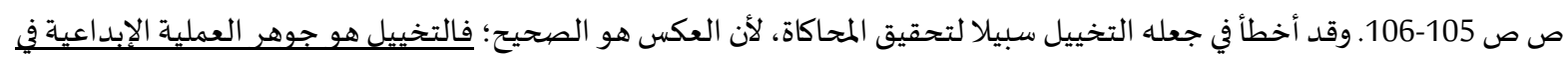
الفن القولي الشعرى عموما. (2) أبو موسى: تقريب المنهاج، مرجع سابق، ص 71. وراجع أيضا فاطمة الوهيبي: نظرية المعنى عند القرطاجني،

$$
\begin{aligned}
& \text { مرجع سابق، ص } 284 .
\end{aligned}
$$

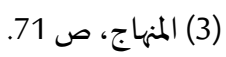

$$
\begin{aligned}
& \text { (4) أبو موسى، تقريب المنهاج، ص صالمان } 72 . \\
& \text { (5) للتفاصيل، محمد أبو موسى، تقريب المنهاج، ص } 78 \text { وما بعدها. }
\end{aligned}
$$


تجرى مجرى النقوش في الصـور والتوشية في الأثواب والتفصيل في فرائد العقود وأحجارها. وقد ذكرت في

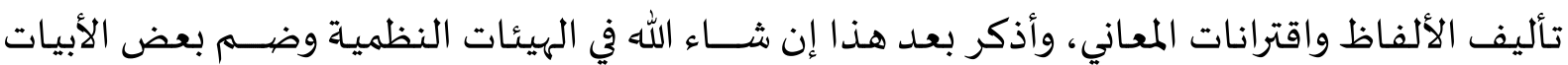

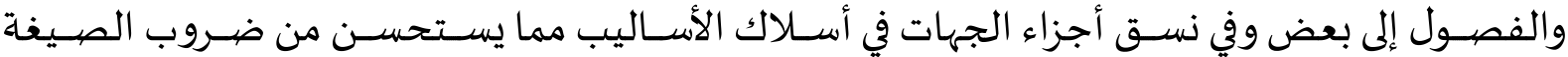
والهيئات المستحسـنة في جميع ذلك ما تغنى بذكره هناك عن أن أنصيه لك هنا. وتلك الصينيخ والهيئات هي

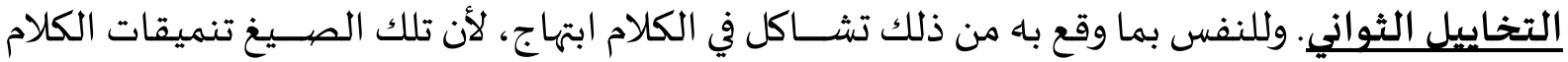

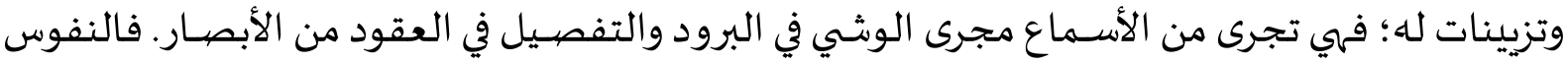

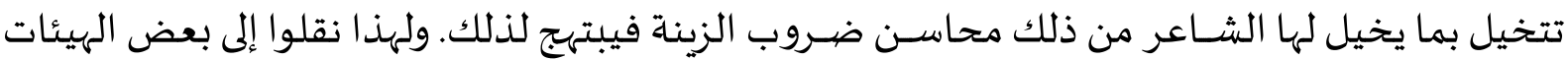

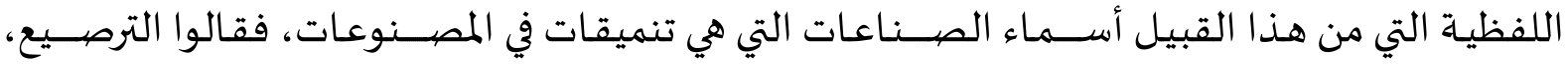
والتوشيح، والتسهيم من تسهيم البرود، وكثير من الكلام الذي ليس بشعري، باعتبار التخييل الأول يكون

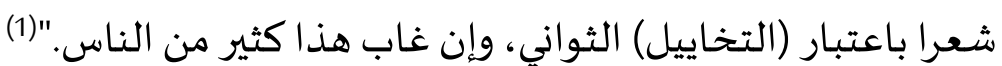

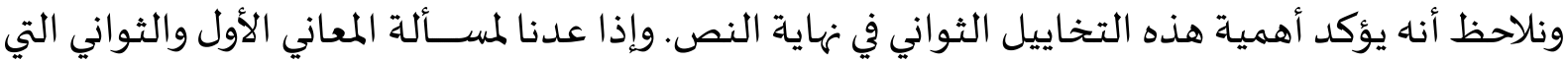

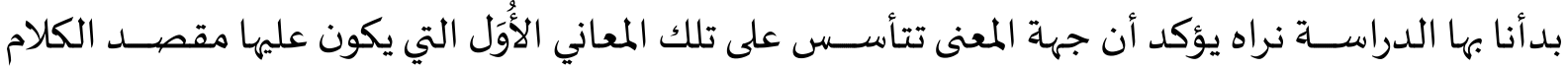

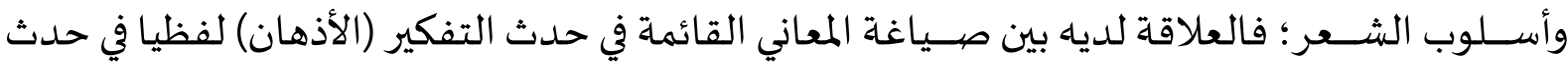

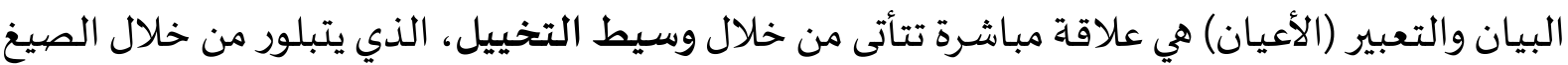

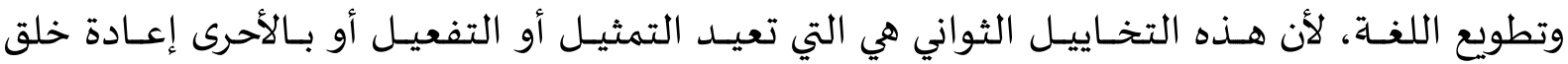

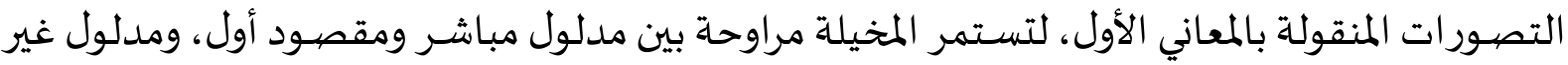

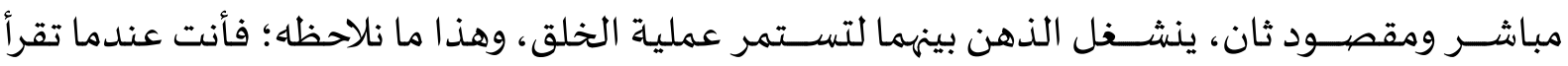
القصيدة مرات ومرات، تتأتى لك صـور ومخيلات مختلفة في كل مرة، حتى تأتي القراءة الأخيرة شيئيا مغايرا

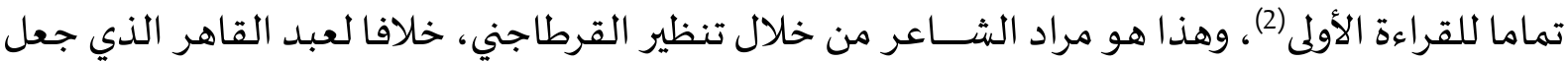

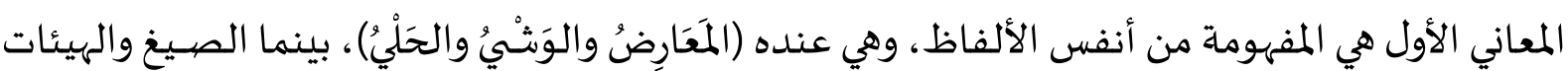
التركيبية عند القرطاجني هي التي تقع في حقل (الثواني) المحفزة للعملية التصورية بأكملها.

2-1-3 والحق أن عملية التخييل تُنتجُ صـورا في مخيلة المتلقي تسـثير قبولا أو نفورا وفق ما هو مقابل لها في الواقع، أو حتى في خيال المتلقي. والنفس، كما يذهب ابن سينا، قد تتبع ـ عادة ـ حكم الوهم في حالات

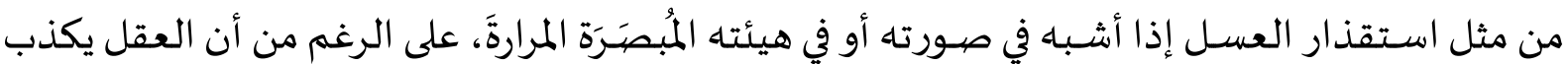

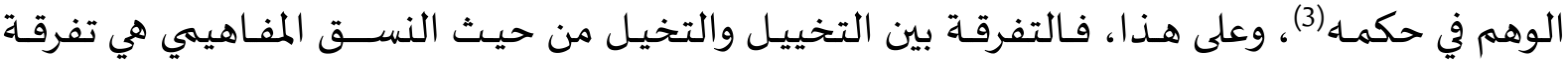

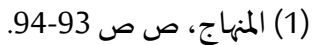
(2) أحب بعض الباحثين التفرقة المصطلحية بين التخييل والتخيل؛ بجعل التخيل خاصا بالمبدع منشئ النص، والتخييل لدى المتلقي فقط،

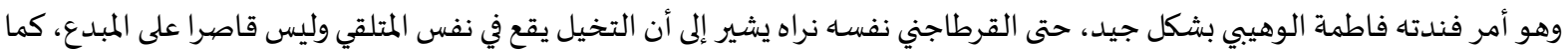

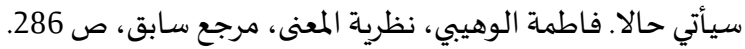

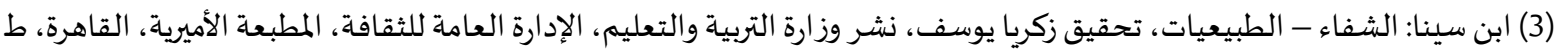

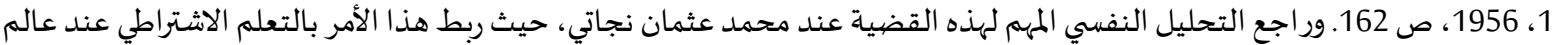

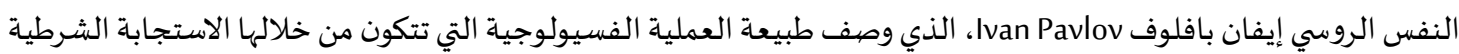


ســــحيـة جـدا؛ يقول القرطاجني: "لما كانت النفوس قـد جُبلت على التنبـه لأنحـاء المحاكاة واســـعمـالها

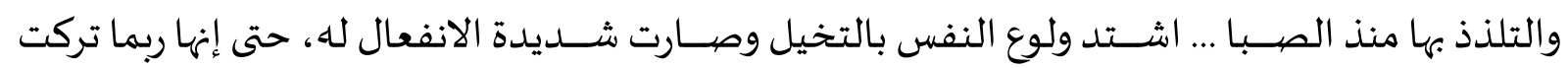
التصـــيق للتخيل فأطاعت تخيلها وألغت تصــديقها."(1) وكلامه هذا يطابق كلام ابن ســـينا تماما وحكمـا على قوة الوهم وتحكمها في الإدراك الحســي؛ فـالعقل قد يكذب الوهم في حكمـه بينما تميل النفسئ مع الوهم؛ أي مع الصـــور الذهنية وفعل الخيال المهيمن على المنافذ العرفانية لإدراك الوجود كله؛ فالتخيل هو عمل قائم في ذهن المبـدع والمتلقي، ويمكننـا القول إن التخييل هو أداة حركية حافزة حـال اشـــتفـال الذهن، بينما التخيل هو البيئة ذاتها، هو جوهر العملية وخلفياتها، فالتخيل قائم بالديمومة، والتخييل فاعل بالصيروةة.

وأختم هذا القسـم وتلك الدراسـة بخلاصـة تحليلية إبسـتمولوجية عن مسـألة التخييل والمحاكاة بأكملها، توجز الرأي وتقارباه.

2-3 إن التحليل اللغوي للعبارات التي يصـــوغها الإنســـان عموما يُفضــي إلى أنه، وفقًا لما يراه "كارناب"

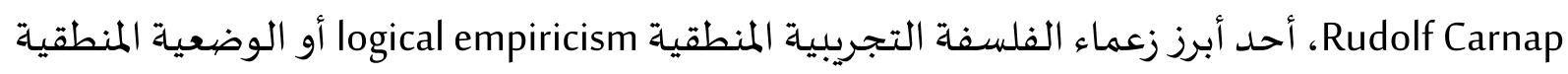

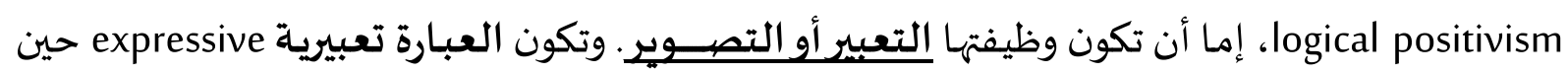
تريد أن تقول إنها منصـرفة إلى إخراج ما يشعر باه القائل داخل نفسـه، مما يستحيل على سـواه أن يراجعـاه

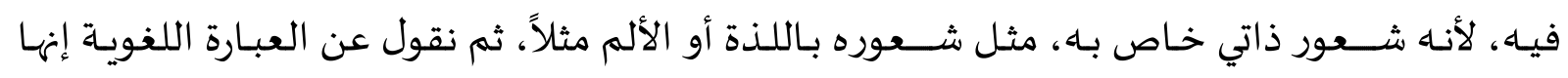

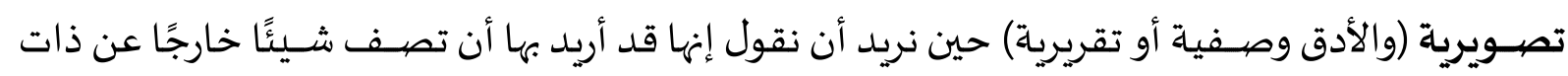

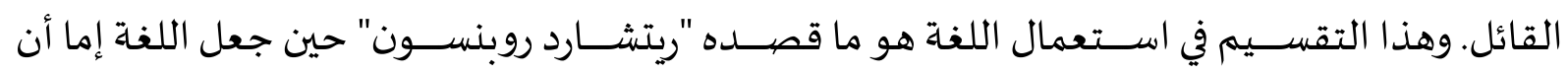

تُستعمل استعمالاً علميا أو استعمالاً انفعاليال(2). وقد رفض الفيلسـوف زكي نجيب محمود نظرية المحاكاة بمعناها الضيق المحلدود، على أسـاس أهنا تدعو كما فهمها من وجهاة نظره عند أفلاطون وأرسطو - إلى أن يقول الشـاعر أو الفنان شيئًا أو معنً مما يصسُّ

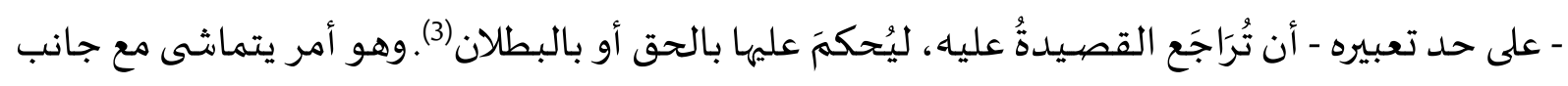

للموجودات من خلال إدراكها بالحواس. وقد استعان الغزالي أيضا بأحكام الوهم من منظور ابن سينا في مناقشة مبدأ التحسين والتقبيح العقلي عند المعتزلة. محمد عثمان نجاتي: الإدراك الحسي عند ابن سينا .. بحثٌّ في علم النفس عند العرب، دار الشروق، بيروت، ط1، 1980، 1980، الفصل الرابع

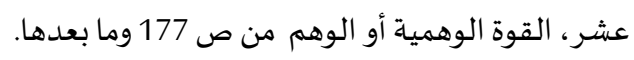

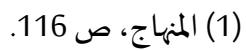
(2) للمزيد من التفاصيل، زكى نجيب محمود: موقف من الميتافيزيقا، دار الشروق، ط3، القاهرة، 1987،

ص ص 113-112.

(3) في مقال له بعنوان: (الشعر لا ينبئ)، يقول: "غفر الله لفلاسفة اليونان الأولين - "أفلاطون" و"أرسطو" على وجه التخصئ التصيص - حين تركوا

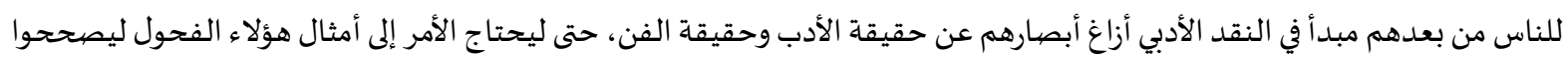

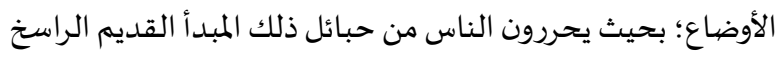
في النفوس، وأعنى به مبدأ المحاكاة الذي يجعل الناعن الفن محاكاة للطبيعة، فإن رسم رسام صورة قالوا لله: ماذا "تعنى" هذه الصهورة؟ أي إنهم 
كبير مما ذهب إليه القرطاجني، الذي فصل عالم الذهن ـإلى حد ما .عن عالم الواقع، كما سلف وأوضحنا

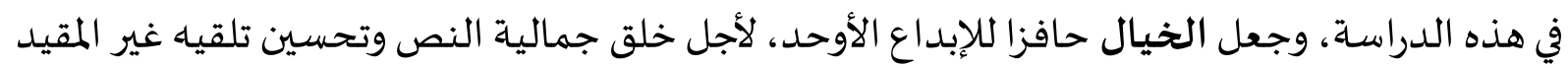

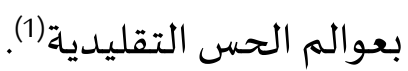

والحقيقة أن "أرسطو" لم يكن يعنى بالقول بالمحاكاة نسخَ الواقعِ هكذا بإطلاق، بل إنه يهتم بالأساس

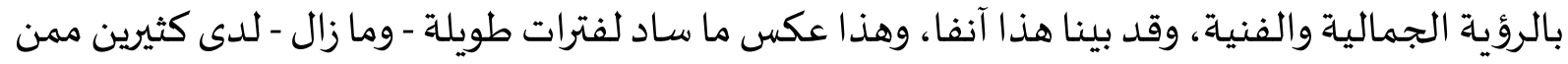

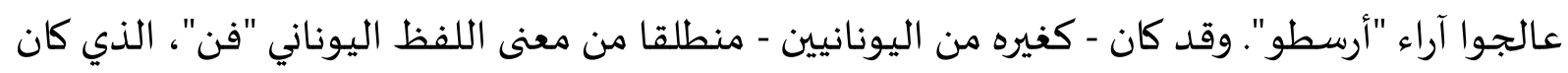

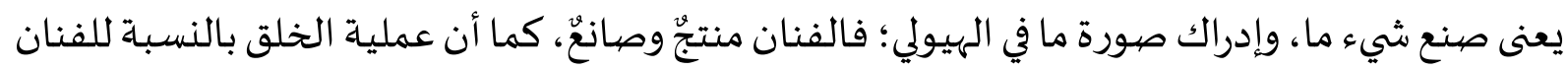

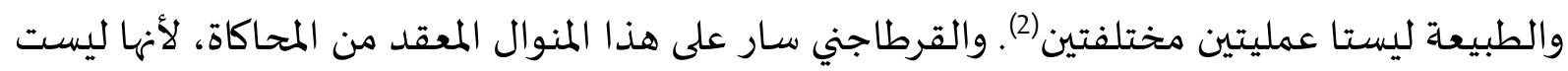

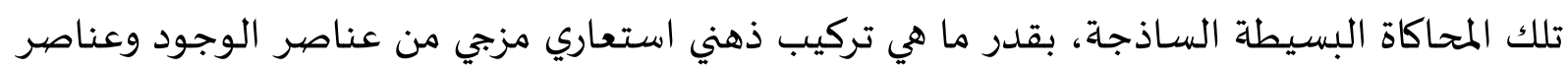

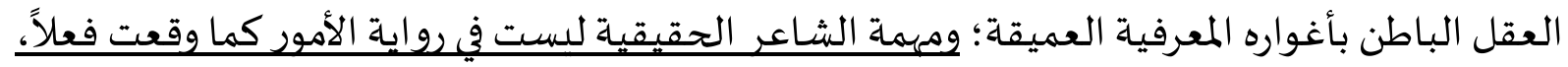

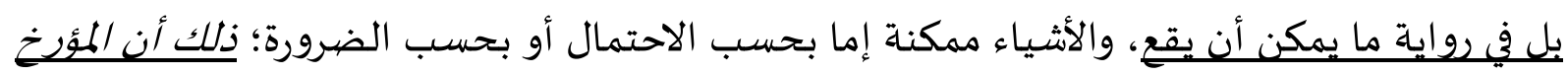

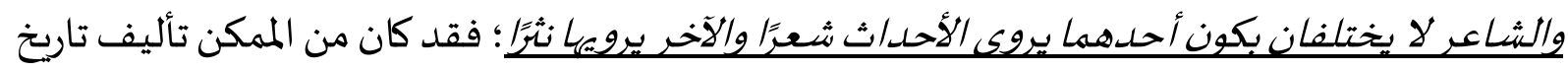

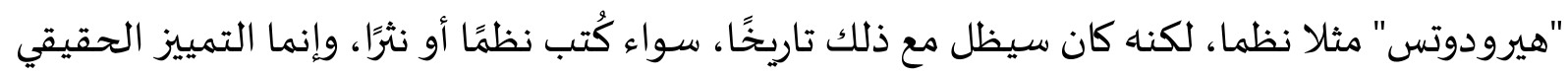

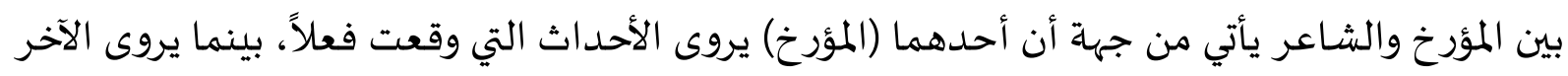

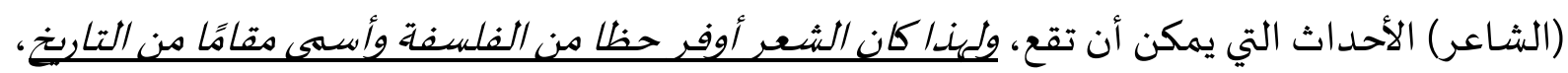

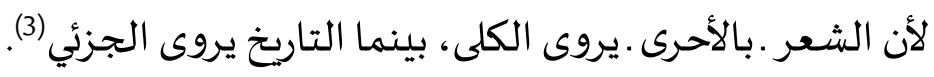

يسألونه أين الثيء في الطبيعة الذي جاءت الصورة لتحاكيه. والويل له إن قال لهم عن صهورته إنها لا تصهور من الطبيعة شيئًا. وإن أنشأ

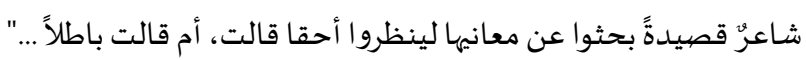

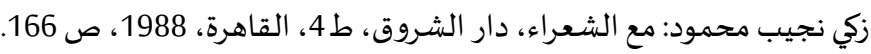

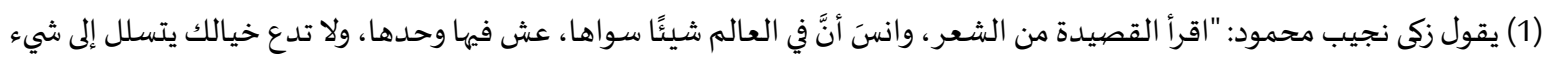

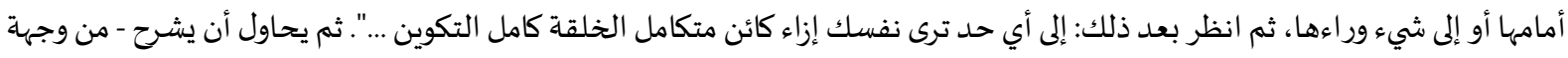

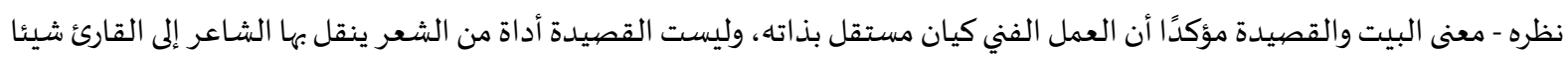

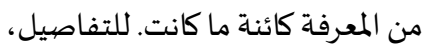

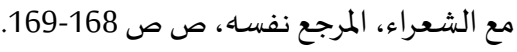

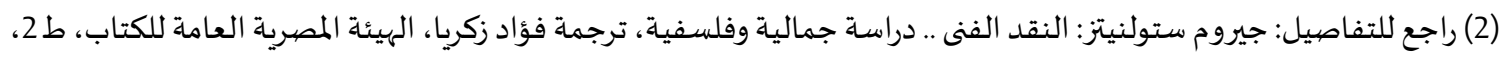

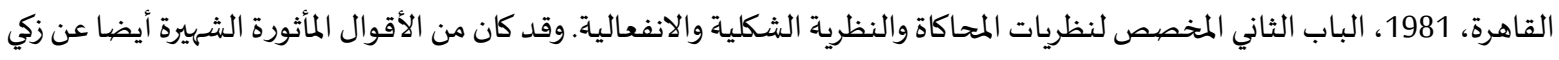

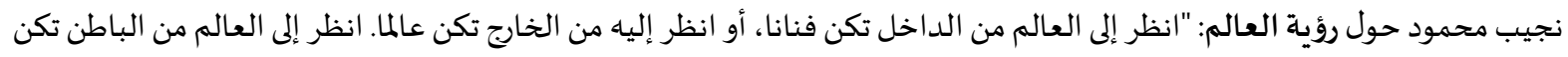

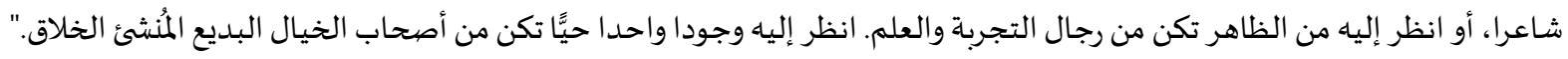
وهو منثور في معظم الكتب التي تحدثت عن فلسفته الجمالية. L- loyed, G.E.R: Aristotle, The growth structure of his Thought, Cambridge university press, $4^{\text {th }}$ published, London, 1980, (3) 
لقد كانت نظرية القرطاجني خيطًا أبيضَ في سماء البلاغة العربية، استحال إلى شمس ساطعة تغمر آفاق الفكر والنظر لكل متأمل فيما طرحاه هذا العالم الذكي الفذ، الذي سبق عصره بآرائه العرفانية الرائدة، وفتوحاته الفلسفية اللسانياة. والحق فيما أشتُهر عن الشيخ الطاهر بن عاشور ـ رحماه الله ـ من أن منهاج البلغاء هو بمنزلة فلسفة العلم من العلم، وبمنزلة مقدمة ابن خلدون من التاريخ، وبمنزلة رسالة الشافعي من الفقها ... إلخ. إن حازم القرطاجني قد حمل راية القول بنسبية الدال والمدلول وعدم الثبات التداولي ـإن جاز التعبير .فيما يخص فنون القول، متجاوزا بذلك آراء البلاغيين المعاصرين له وسابقيه؛ حيث قفز . ببراعة . إلى ما طُرح

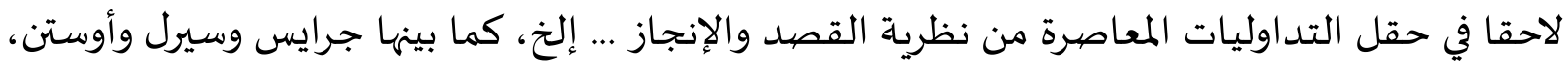
وتلاميذهم. وقد استند في تحليلاته على العبارات الجمالية التداولية، وأخذ يفند مسائل المعاني الأول والثواني، والتخييلات الأول والثواني، وأيها يحمل الفكر، وأيها يوقع في الإدراك تخييلا بالاستحسان والنفور؛ فتركيزه على عنصر التخييل تحديدا في بلورة الصورة الذهنية بين المبدع والمتلقي هو من صلب مباحث الدماغ المعاصرة، مع اختلاف البواعث والمنطلقات، وهو تركيز أخذه عميقا داخل تحليل الوجود ذاتها المُنشَأ بالفكرة داخل عقل الإنسان، لأنني أومن تماما بأن أبحاث الذهن والدماغ هي نظير أبحاث الكون، بما يشملها

$$
\text { هذان الوعاءان من غموض مبهر. }
$$

لقد فطن القرطاجني إلى أن العبارة الجمالية في الشعر، ونجاح توصيل المعنى (تداوليا)، لا تُحمل بالتركيب

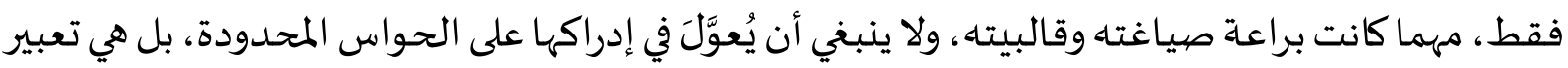
عن الانفعال الذهني المرتبط بقوةٍ بعالم الخيال الإبداعي في ذهن الشاعر وذهن المتلقي للنص، وهو ما أطلق عليه زكي نجيب محمود (فعل الخلق) في مقابل نظريتي المحاكاة والتعبير ، إن قُصديد بهما المجال المحدود الضيق، من تقليد الطبيعة والقياس على أعيانها ... إلخ. وقد خرجنا بعد هذه الجولة البلاغية التي طفنا فيها في بعض جوانب "المنهاج" بأمور عاماة، سبق تحليل جزئياتها، وخلصنا إلى أن الكليات المعرفية للمعنى عند القرطاجني متحققة بصورة تجاوز كثيرا ما سبقه من جهد بلاغي، بل إنها تمتزج فلسفيا ومنطقيا بأطروحات جعل منها القرطاجني .بهذا المزج . نظرية قائمة برأسها في صلب البلاغة العربية. كما أن الدراسـة قد طرحت بعض جوانب الأنظمة الدلالية والإشارية، ومن خلالها حُددت بعض جوانب توسيع القرطاجني لطرق وقوع التخييل عند المتلقي خصيوصا، وتركيزه على مركزية المعنى ضمن الأنظمة الإشـارية بتحققاته الأربعة (في الفكر، أو بالإشـارة العضوية، أو بالمنطوق، أو بالمكتوب).

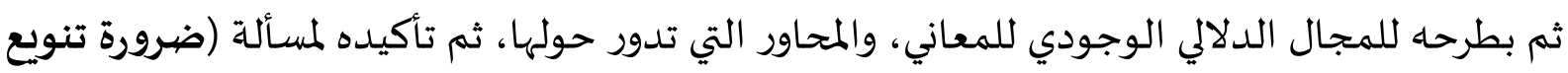

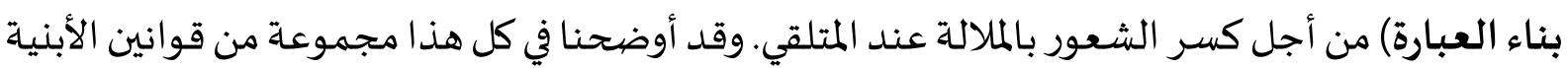
التداولية مع أمثلتها وتحليلها المنطقي اللساني. وخُتمت الدراسـة بعرض رأينا مع الاستعانة ببعض المقاربات النقدية الحديثة حول جدانية المألنساق المفاهيمية على مستوى جمالية التلقي من خلال دعامتي المحاكاة والتخييل. ومن النتائج أو القواعد جدائ العرفانية التي أستخلصت عموما حول تداولية المعنى عند القرطاجني: جمئي 
عامل الإههام أو القوة الوهمية هي حافز للانفعال بجمالية التلقي. جوهر الشعر هو التخييل والمحاكاة هي أداة التخييل، وليس العكس.

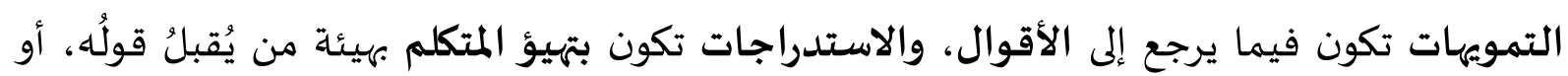

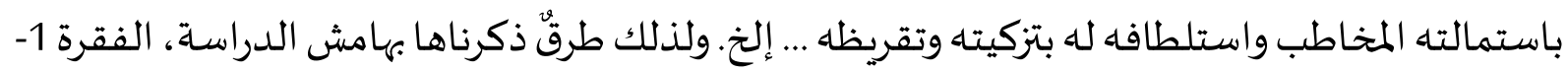

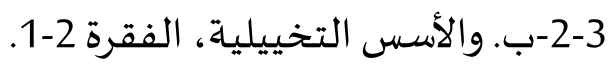

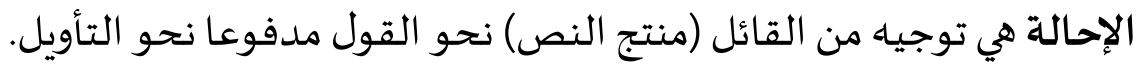

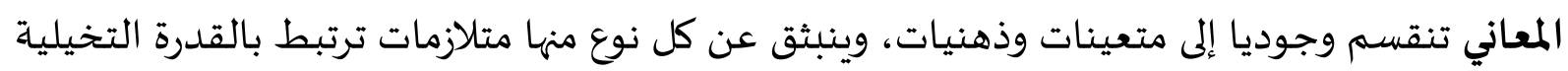

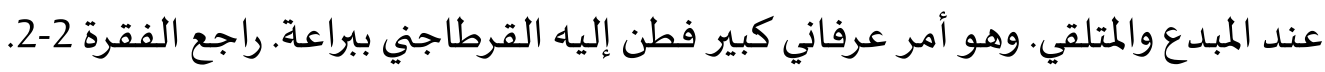

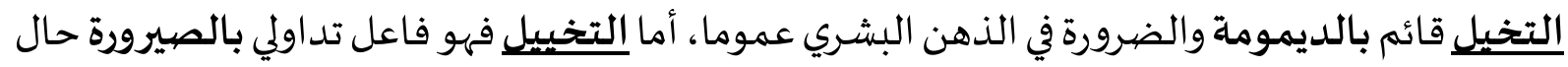
الانشغال بعملية التلقي الانفعالية. متواليات اقتران المعاني عند القرطاجني تتمثل في: اقتران التماثل والمناسبة والمطابقة أو المقابلة والمخالفة

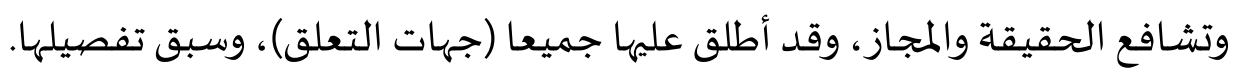

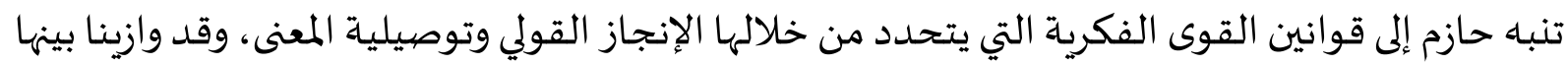

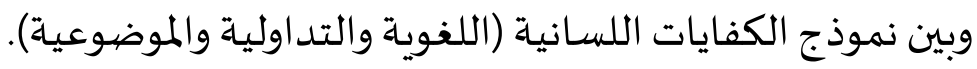

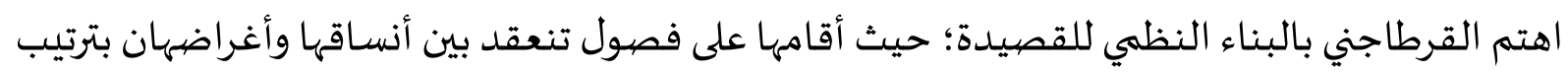

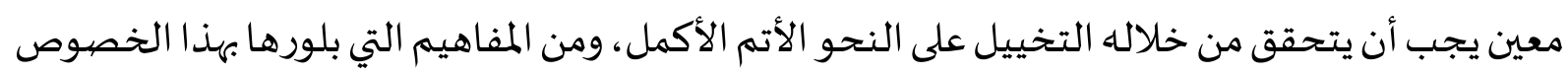

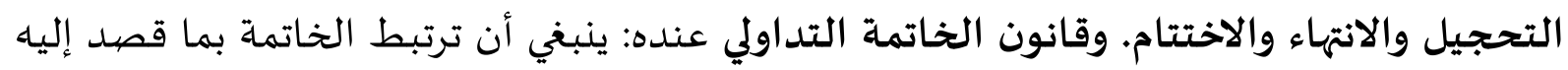

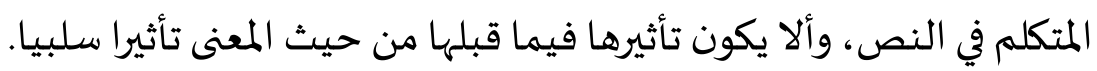

\section{• •المصبادروالمراجع:}

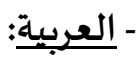

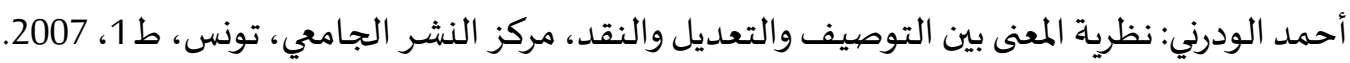

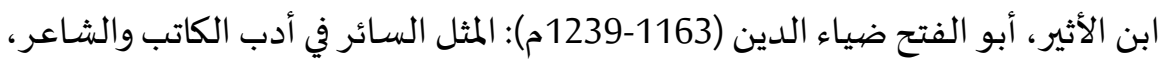

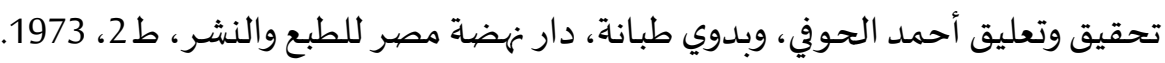

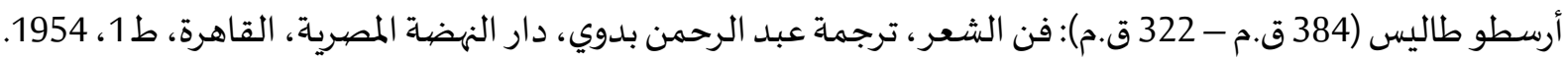

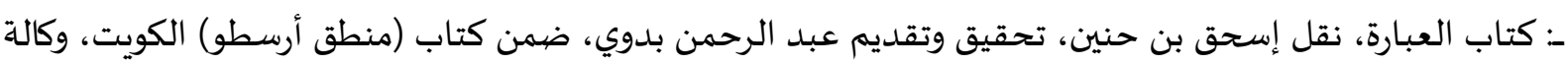

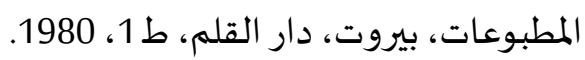

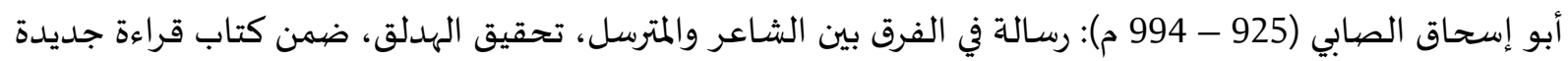

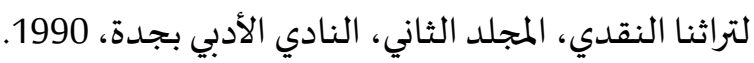
جيروم ستولنيتز: النقد الفنى .. دراسة جمالية وفلسفية، ترجمة فؤاد زكريا، الهيئة المصرية العامة للكتاب، ط2، المائلة القاهرة، 
حبيب الله علي إبراهيم: نظرية المحاكاة عند حازم القرطاجني، مجلة الأثر، العدد 13، مارس 2012.

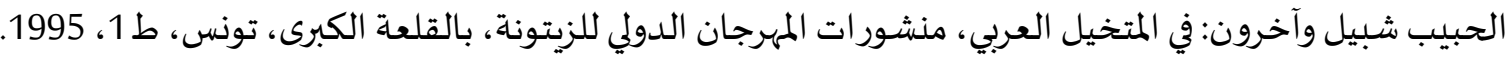

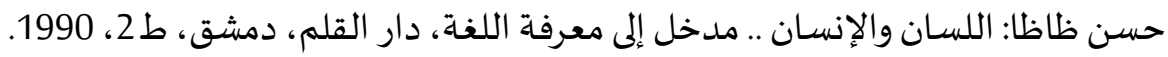
حمادي صمود: نظرية المعنى في التراث العربي وأثرها في فهم وظيفة الصورة، ضهمن كتاب (في نظرية الأدب عند العند العرب)،

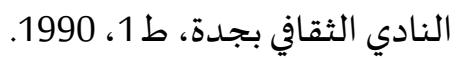
خالد سعد كموني: المحاكاة .. دراسة في فلسفة اللغة العربية، المركز الثقافي العربي، ط2 2، 2014. ابن خلدون، أبو زيد عبد

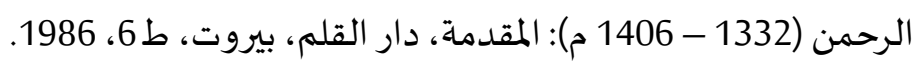
خليل شيرزاد علي: الشعري والسردي .. حدود التمفصل والتمازج، جامعة كرميان، كلية العلوم الإنسانية والرياضية، كردستان العراق، مجلة العميد، العدد السابع، سبتمبر ، دورئ، 2013.

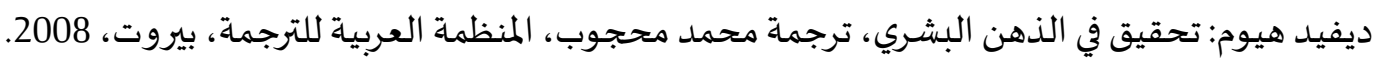

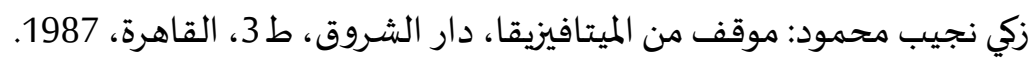

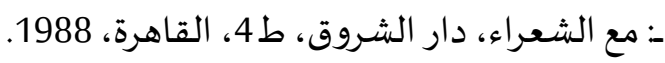
زهير الخويلدي: ما لديكارت وما على الديكارتية، مقالة منشورة بموقع ملتقى ابن خلدون للفلسفة والأدب، بتاريخ :2014/12/26

http://ebn-khaldoun.com/article_details.php?article=1975

ابن سينا، أبو علي الحسين (980 - 1037 م): فن الشعر، ضمن مجموعة ترجمات الكتاب، تحقيق عبد الرحمن بدوي، نشر نهضية مصر، ط 1، 1953.

- - الشفاء، المنطق، العبارة، تحقيق محمود الخضيري، دار الكتاب العربي، القاهرة، د.ت.

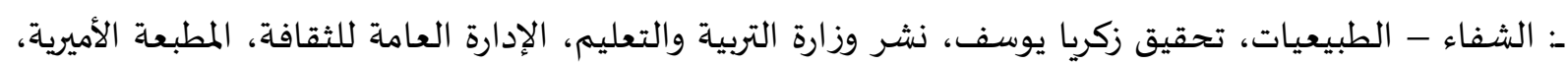
القاهرة، ط 1 1956، 1956. شاكر عبد الحميد: الخيال .. من الكهف إلى الواقع الافتراضي، سلسلة عالم المعرفة، الكويت، العدد 360، فبراير، 2009.

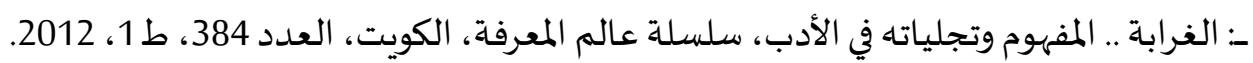
عبد الحكيم راضي: دراسات في النقد العربي (التاريخ - المصطلح - المنهج)، مبحث: التغير الدلالي في المصطيح المادئ النقدي:

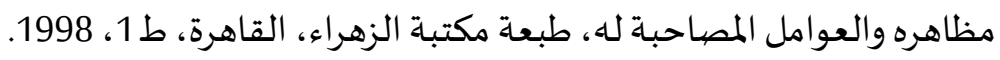

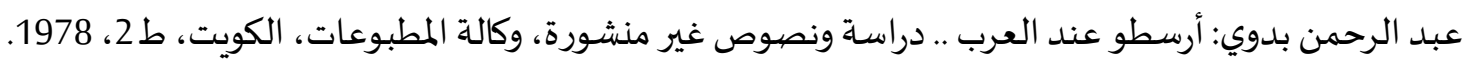

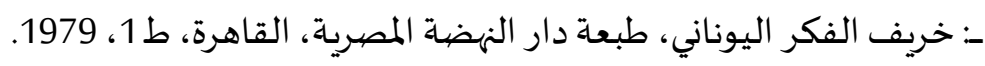

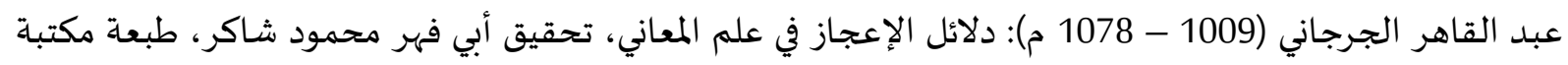

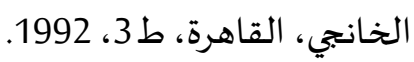
فاتن فاضل وأمل الشرع: أصول ظاهرة التلاحق عند القدماء، مجلة جامعة بابل للعلوم الإنسانية، المجلد 23، العدد 3، .2015

فاطمة عبد الله الوهيبي: نظرية المعنى عند حازم القرطاجني، المركز الثقافي العربي، الدار البيضاء، المفرب، ط1، 2002.

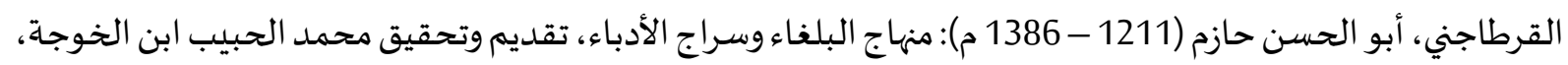
دار الكتب الشرقية، تونس، ط 1 1، 1966.

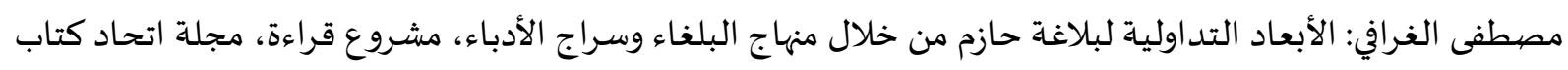

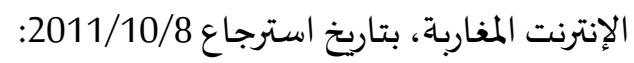

$\underline{\text { www.ueimarocains.wordpress.com }}$ 
محمد عثمان نجاتي: الإدراك الحسي عند ابن سينا .. بحثٌ في علم النفس عند العرب، دار الشروق، بيروت، ط 1، 1980.

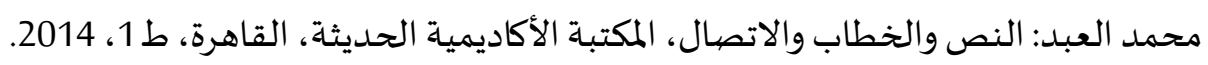

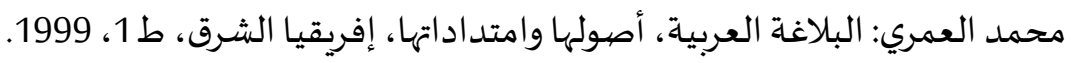

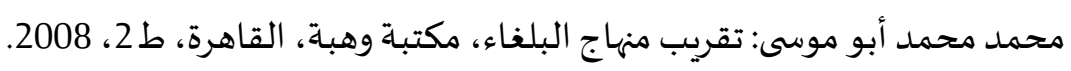

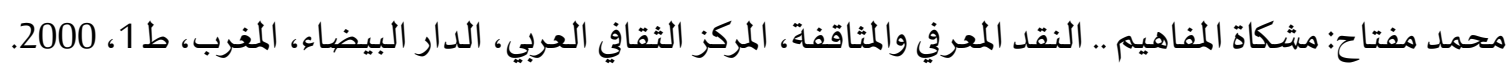

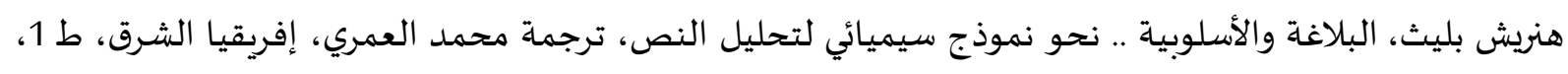

Ch. Perelman: L‘empire Rhétorique, Librairie Philosophique,

Paris, 1977.

G. Genette: Rhétorique restreinte, Edition du seuil, Paris, 1972.

L- loyed, G.E.R: Aristotle, The growth structure of his Thought,

Cambridge university press, 4th published, London, 1980. 


\section{فهرس المواد}

3 تعريف بالمؤتمر..

6.

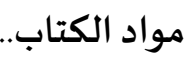
الهحور الأول: التجديد في المفاهيم: الهحاكاة والتخييل والتناسب

8. المعاني الثواني عند حازم: كشف وبيان ونمذجة .

أ.د.محمد الحافظ الروسي ، رئيس شعبة اللغة العربية وآدابها ، كلية الآداب تطوان

24.

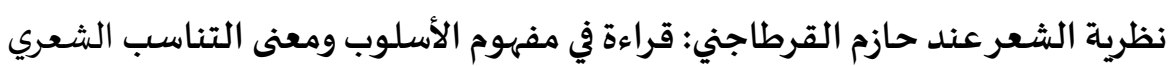

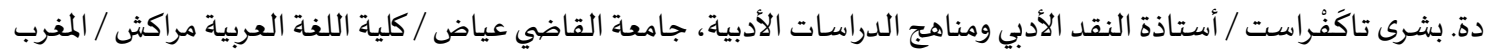
41 مفهوم الشعروقضاياه لدى حازم القرطاجني...

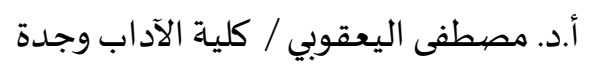

56. المحاكاة والتخييل، "رؤية جديدة للتصوير الشعري عند حازم القرطاجني" .

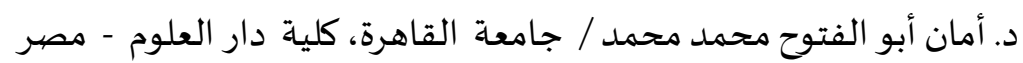

\section{المحور الثاني: التجديد في الرؤية الشعرية والنقدية}

83

140 مظاهر التجديد في التفكير النقدي عند حازم القرطاجني.. د. محمد القاسمي / كلية الآداب سايس فاس.

147 النظم عند حازم، دراسة في المفهوم والمصطلح... د. عدنان أجانة / كلية الآداب تطوان

160. إشكال الأصهول بين حازم القرطاجني (ت684هـ) وميثم البحراني (ت679هـ)... 


\section{المحور الثالث: التجديد في البلاغة والعَروض}

183.

إشكالية الوزن والغرض عند حازم القرطاجني.

أ.د. عبد الإله كنفاوي / كلية الآداب تطوان.

198. أعاريض الشعرعند حازم القرطاجني، من التعليمية النظرية إلى الاعتبارات البلاغية..

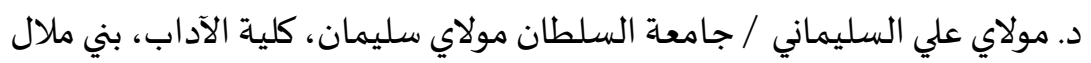
د. عبد الواحد الصمدي / معهد محمد السـادس للقراءات والدراسات القرآنية بالرباط، جامعة القرويين.

\section{المحور الرابع: تجديد حازم في ميزان النظريات الحديثة.}

النَّظريَّة الشِّعرية في كتاب: "هنهاج البلغاء وسراج الأُدباء《 لحازم القرطاجنّي 252

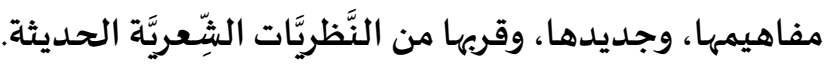

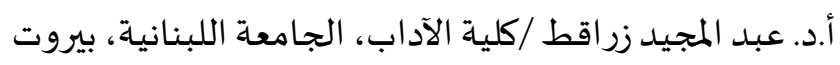

277. ترويض النص وإشكالية التوصيل، رؤية في جذور نظرية الاستقبال في "منهاج البلغاء《..

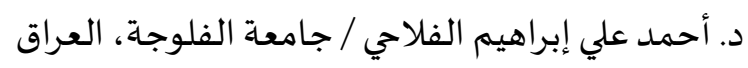

288. تداولية المعنى عند حازم القرطاجني: الأسس المنطقية والتناول اللسـاني.

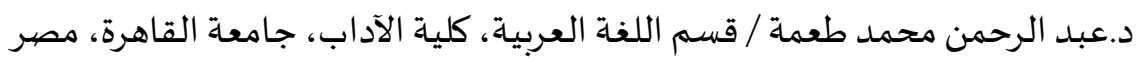
د. بدر بن سالم بن جميل القطيطي / كلية العلوم التطبيقية بالرستاق، سلطنازية عماندان. الأعراف التداولية في نقد حازم القرطاجني...

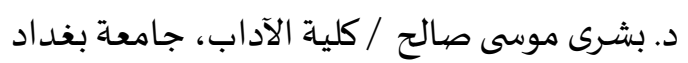

